UNIVERSIDADE DE SÃO PAULO

INSTITUTO DE QUÍMICA DE SÃO CARLOS

Mariana Provedel Martins

\title{
Biotransformação de epóxidos com fungos de origem marinha e síntese de cloroidrinas
}

Dissertação apresentada ao Instituto de Química de São Carlos, da Universidade de São Paulo, para obtenção do Título de Mestre em Ciências área de concentração Físico-Química

Orientador: Prof. Dr. André Luiz Meleiro Porto 
Dedico este trabalho à minha mãe Nina pelo apoío incondicional em todos os momentos da minha vida 


\section{AGRADECIMENTOS}

Agradeço a Deus por tudo que tem me concedido até hoje.

Aos meus pais, Tadeu e Nina, pelo apoio e confiança ao longo de todos esses anos.

Ao meu irmão Eliud pelo seu companheirismo e preocupação.

À minha cunhada Adriana pelo apoio de sempre.

Especialmente ao Professor André, por me dar a oportunidade de trabalhar em seu Grupo, pela sua orientação, paciência e dedicação.

Ao Ítalo, pelo encadernamento da tese e pela ajuda oferecida.

À minha veterana Milena, pela amizade desde a época de graduação e por todo apoio durante esses anos de estudo em São Carlos.

À Fran pela amizade, confiança e preocupação. Obrigada por ser uma irmã pra mim (não de sangue, mas com certeza uma das maiores que a vida me deu).

Às minhas amigas de Araraquara Xicória, Tchica e Débora pela amizade e companheirismo.

À Letícia pela amizade e por toda a ajuda fornecida para a continuidade do projeto.

Aos ICs e amigos de laboratório Eduardo e Scarlet pela amizade.

À amiga Ana Maria pela sua amizade, confiança e compreensão. 
Ao amigos de laboratório Lenilson e Hércules, pelos ensinamentos, pela confiança e pela paciência durante todo esse ano. Obrigada por sempre estarem dispostos a ajudar e tornarem os meus dias de trabalho mais proveitosos.

À Richele, por todo apoio dado.

Às faxineiras Cleusa e Eva pelo bom humor de sempre.

Aos técnicos do CAQI: Mauro (IV), Paulo (CG) e Silvana (RMN) pelas análises realizadas.

Ao Instituto de Química de São Carlos/USP, pelo apoio institucional.

Ao CNPQ pela bolsa de mestrado.

À FAPESP pelo financiamento do projeto. 


\section{SUMÁRIO}

LISTA DE FIGURAS

LISTA DE TABELAS

LISTA DE ABREVIATURAS

RESUMO

\section{ABSTRACT}

1 INTRODUÇÃO

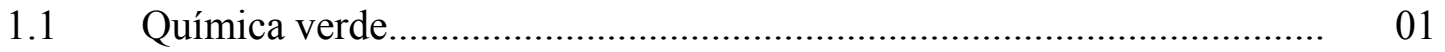

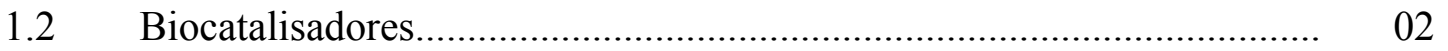

1.3 Aplicações industriais das enzimas........................................................... 08

1.4 Resolução enzimática........................................................................ 10

1.5 Métodos analíticos para a determinação da pureza enantiomérica........... 12

1.5.1 Método polarimétrico...................................................................... 12

1.5.2 Cromatografia gasosa quiral (CGQ) ................................................... 14

1.5.3 Cromatografia líquida de alta eficiência - CLAE.................................. 15

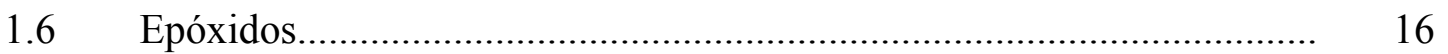

$1.7 \quad$ Epóxido hidrolases........................................................................ 18

1.8 Revisão bibliográfica para EHs......................................................... 21

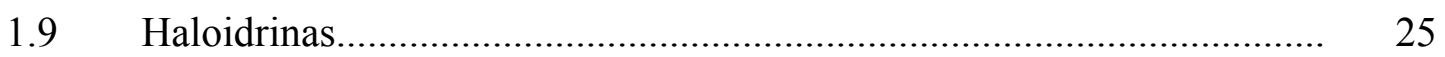

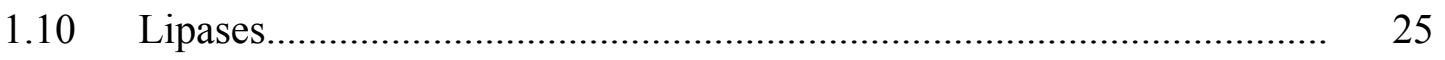

$\begin{array}{llr}2 & \text { OBJETIVOS } & 27\end{array}$ 
3.1 Biotransformação de epóxidos racêmicos por microrganismos de origem marinha.

3.1.1 Síntese de dióis por método químico

3.1.2 Caracterização dos dióis racêmicos por métodos espectroscópicos

3.1.3 Reações enzimáticas

3.1.3.1 Crescimento dos organismos

3.1.3.2 Síntese de dióis por biocatálise.

3.2 Síntese e resolução enzimática de cloroidrinas.

3.2.1 Síntese de cloroidrinas a partir de epóxidos racêmicos..

3.2.2 Síntese de acetatos por método químico.

3.2.3 Caracterização das cloroidrinas e do acetato 4c por métodos espectroscópicos

3.2.4 Reações enzimáticas

3.3 Materiais e equipamentos utilizados.

3.3.1 Reagentes e solventes.

3.3.2 Cromatografia em coluna.......

3.3.3 Espectroscopia de infravermelho (IV)......

3.3.4 Espectroscopia de ressonância magnética nuclear (RMN).

3.3.5 Polarímetro

3.3.6 Cromatografia a gás (CG) 
3.3.9 Agitador orbital rotativo termostatizado............................................ 40

3.3.10 Outros equipamentos utilizados.......................................................... 40

$4 \quad$ RESULTADOS E DISCUSSÕES 41

4.1 Biotransformação de epóxidos racêmicos por microrganismos de origem marinha...

4.1.1 Síntese de dióis racêmicos por método químico

4.1.2 Análise cromatográfica dos epóxidos e dos dióis racêmicos

4.1.3 Triagem dos microrganismos

4.1.4 Otimização das reações de biocatálise com o microrganismo Trichoderma sp.Gc1 para o epóxido 2.

4.1.4.1 Crescimento do microrganismo na ausência de sais.

4.1.4.2 Variação da massa de biocatalisador empregada.

4.1.4.3 Variação do tempo de reação.

4.1.5 Reações de biocatálise dos epóxidos 1-5 com o microrganismo Trichoderma sp.Gc1

4.2 Síntese e resolução enzimática de cloroidrinas.

4.2.1 Síntese de cloroidrinas a partir de epóxidos racêmicos.

4.2.2 Resolução enzimática de 1-alilóxi-3-cloro-2-propanol (4b) com a lipase de Candida antarctica (CALB) comercial Novozym ${ }^{\circledR} 435$.....

4.2.2.1 Síntese de acetato racêmico obtido por método químico.

5 CONCLUSÕES

6 REFERÊNCIAS BIBLIOGRÁFICAS 


\section{LISTA DE FIGURAS}

Figura 1. Formação da ligação peptídica entre dois aminoácidos.

Figura 2. Efeito da concentração de substrato sobre a velocidade inicial da reação catalisada por enzimas. (A) Gráfico da velocidade inicial da reação versus concentração de substrato. (B) Relação de Lineweaver-Burk

Figura 3. Modelo chave fechadura proposto por Fischer.

Figura 4. Modelo do ajuste induzido de Koshland

Figura 5. Enantiômeros da talidomida.

Figura 6. Diagrama de energia para uma reação enantiosseletiva catalisada por enzima.....

Figura 7. Exemplos de epóxidos biologicamente importantes.

Figura 8. Produtos da abertura de epóxidos com diferentes nucleófilos

Figura 9. Abertura do epóxido estireno em meio ácido.

Figura 10. Esquema da resolução enzimática de um alquil-epóxido

Figura 11. Mecanismo da hidrólise enzimática do epóxido.

Figura 12. Hidrólise enzimática de epóxidos com retenção e inversão de configuração.

Figura 13. Resolução de epóxidos usando EHs de Aspergillus niger.

Figura 14. Resolução de epóxidos usando EH de Beauveria sp.

Figura 15. Resolução do óxido de indeno catalisada por EH de Diploida gossipina.. 24

Figura 16. Estrutura tridimensional da lipase B de Candida antarctica (CALB)...... 26

Figura 17. Epóxidos racêmicos comerciais utilizados na síntese de dióis em meio ácido

Figura 18. Fotos das esponjas das quais os microrganismos foram isolados e dos fungos em meio de cultura sólido utilizados em nosso laboratório 
Figura 19. Dióis obtidos a partir da abertura de epóxidos em meio ácido.

Figura 20. Cromatogramas dos epóxidos racêmicos comerciais.

Figura 21. Cromatograma do diol (RS)-2a obtido por método químico

Figura 22. Cromatograma do epóxido $(R S)-2$ em: água destilada; água destilada + malte; tampão fosfato $(\mathrm{pH}=7)$.

Figura 23. Cromatograma da cloroidrina $(R S)$-2b obtida em água do mar artificial a partir do epóxido $(R S)-2$

Figura 24. Síntese de cloroidrina $2 \mathbf{b}$ via água do mar artificial

Figura 25. Cromatograma para a reação do epóxido 2 com o fungo Aspergillus sydowii Gc12 (5 dias)

Figura 26. Cromatograma para a reação do epóxido 2 com o fungo Trichoderma sp. (5 dias)

Figura 27. Cromatogramas para a reação do epóxido 2 com as células do fungo Aspergillus sydowii Gc12

Figura 28. Cromatogramas para a reação do epóxido 2 com as células do fungo Trichoderma sp.Gc1

Figura 29. Cromatograma da hidrólise do epóxido (RS)-2 com o fungo Trichoderma sp.Gc1 em 25 h de reação.

Figura 30. Conversão do diol 2 a em seu respectivo acetato $2 c$ 54

Figura 31. Cromatograma da esterificação do diol-2a após 24 h de reação 54

Figura 31a Hidrólise seletiva do (RS)-2a com o fungo Trichoderma sp GC1 55

Figura 32. Cromatogramas dos dióis $(R S) \mathbf{1 a},(R S) \mathbf{3 a},(R S) \mathbf{4 a}$ e $(R S) 5 \mathbf{a}$ obtidos por método químico

Figura 33. Cromatograma do epóxido $(R S)-1$ em tampão fosfato $(\mathrm{pH}=7)$ 57

Figura 34. Cromatograma do epóxido $(S)$-4 obtido na reação de biocatálise com o 58 fungo Trichoderma sp.Gc1

Figura 35. Cromatograma do epóxido $(R S)-5$ obtido na reação de biocatálise com o fungo Trichoderma sp.Gc1

Figura 35a Hidrólise seletiva do (RS)-4a com o fungo Trichoderma sp GC1 
Figura 36. Cromatogramas dos epóxidos 1-5 para reação em $\mathrm{NaCl}$ e água................. 62

Figura 37. Síntese de cloroidrinas a partir dos epóxidos 2, 3 e 4............................ 63

Figura 38. Acetato obtido a partir da cloroidrina 4b............................................ 64

Figura 39. Cromatograma do acetato $(R S) 4$ c obtido por método químico.................... 65

Figura 40. Cromatogramas para a reação da cloroidrina 4b com a lipase.................. 67 


\section{LISTA DE TABELAS}

Tabela 1. Classificação das enzimas segundo a UIBBM....................................... 06

Tabela 2. Enzimas utilizadas em diferentes segmentos industriais........................ 09

Tabela 3. Programas utilizados no cromatógrafo a gás para a coluna quiral de 39 ciclodextrinas.

Tabela 4. Hidrólise do epóxido 2 com o fungo de origem marinha A. sydowii 46 Gc12............................................................

Tabela 5. Hidrólise do epóxido 2 com o fungo de origem marinha Trichoderma 48 sp.Gc1.

Tabela 6. Hidrólise do epóxido 2 com o fungo de origem marinha Trichoderma sp.Gc1.

Tabela 7. Medidas de rotação ótica para o epóxido 2 e o diol 2a obtidos na reação de biocatálise com o fungo Trichoderma sp.Gc1.

Tabela 8. Hidrólise dos epóxidos 3,4 e 5 com o fungo de origem marinha Trichoderma sp.Gc1.

Tabela 9. Esterificação da cloroidrina 4 b com a lipase comercial Novozym ${ }^{\circledR} \mathbf{4 3 5} \ldots . .66$ 


\section{LISTA DE ABREVIATURAS}

$$
\begin{aligned}
& \mathrm{CC}=\text { cromatografia em coluna } \\
& \mathrm{CCD}=\text { cromatografia em camada delgada } \\
& \mathrm{CG}=\text { cromatografia gás } \\
& \mathrm{d}=\text { dupleto } \\
& \text { DMSO }=\text { dimetil sulfóxido } \\
& \mathrm{IV}=\text { infravermelho } \\
& \mathrm{J}=\text { constante de acoplamento } \\
& \mathrm{m}=\text { multipleto } \\
& \mathrm{s} \mathrm{l}=\text { singleto largo } \\
& \mathrm{t}=\text { tripleto } \\
& \mathrm{RMN}{ }^{13} \mathrm{C}=\text { ressonância magnética nuclear de carbono } \\
& \mathrm{RMN}{ }^{1} \mathrm{H}=\text { ressonância magnética nuclear de hidrogênio } \\
& \delta=\text { deslocamento químico }
\end{aligned}
$$




\section{RESUMO}

Neste trabalho realizou-se uma triagem com os fungos de origem marinha Trichoderma sp Gc1, Penicillium miczynskii Gc5, Penicillium raistrickii Ce16 e Aspergilus sydowii Gc12 para catalisar a abertura do (RS)-2-(benziloximetil)oxirano (2). O melhor resultado foi obtido com o fungo Trichoderma sp Gc1, pois forneceu o (R)-(-)-2(benziloximetil)oxirano (2) com excesso enantiomérico de $60 \%$ e rendimento isolado de $39 \%$; o diol (S)-(+)-1,2-propanodiol-3-fenilmetóxi (2a) com excesso enantiomérico de $32 \%$ e rendimento de 19 \%. Posteriormente, otimizou-se as condições experimentais com o epóxido 2 e o fungo Trichoderma sp Gc1, variando-se a massa de biocatalisador, o meio de cultura e o tempo de reação. Os melhores resultados sob essas condições foram aplicadas para os epóxidos 3-5 fornecendo o $(S)-(+)-2-[4-m e t o x i f e n o x i) m e t i l]$ oxirano $(3 a),(S)-(+)-2-($ propeniloxi)oriano (4), (R)-(+)-1-alilóxi-2,3-propanodiol (4a) e o (-)-9-deceno-1,2-diol (5a). Nesses estudos embora tenha ocorrido a abertura seletiva dos epóxidos com as células totais do fungo Trichoderma sp Gc1, não obteve-se altas purezas enantioméricas dos produtos. Ainda nesse trabalho realizou-se a síntese das cloroidrinas racêmicas, a $(R S)$ - 1-cloro-2-propanol- 3fenilmetóxi (2b), (RS)- 1-cloro-2-propanol- 3-(4-metoxifenóxi) (3b) e (RS)- 1-alilóxi-3-cloro2-propanol (4b) em bons rendimentos e uma metodologia sintética ambientalmente apropriada, pois os compostos foram preparados em meio aquoso na presença de íons cloreto. Em seguida realizou-se uma resolução enzimática da $(R S)$-1-alilóxi-3-cloro-2-propanol (4b) com a lipase de Candida antarctica onde obteve-se a clorodrina 4a (e.e. $72 \%$ ) e o seu correspondente produto acetilado 4c (e.e. $82 \%$ ) em bons excessos enantioméricos. Conclui-se que os fungos de origem marinha utilizados neste trabalho são potenciais fontes de epóxido-hidrolases para promover a abertura seletiva de epóxidos. 


\section{ABSTRACT}

In this work carried out itself the first study biocatalytic involving reactions of reduction of cetonas with fungi of marine origin. They were utilized 7 cetonas commercial as substratos and 8 fungi derived little seas like biocatalisadores. The fungi were isolated of the sponges little seas Geodia corticostylifera (Trichoderma sp Gc1, Penicillium miczynskii Gc5, Aspergillus sydowii Gc12) and Chelonaplysylla erect (Bionectria sp Ce5, Aspergillus sydowii Ce15, Penicillium raistrickii Ce16 and Aspergillus sydowii Ce19). The reduction 2-chloro-1-phenylethanone (1) was studied under several conditions of reaction (changes of $\mathrm{pH}$, addition or absence of glucose) and the best result was with fungus $P$. miczynskii Gc5, therefore itself obteve an isolated performance of $60 \%$ and excess enantiomeric of $50 \%$ for the (S)- 2-chloro-1phenylethanol (1a). The interesting one in these studies was that all of the fungi utilized in the selection with the 2-chloro-1-phenylethanone (1) presented selectivity antiPrelog. In the literature is common obtain reduction enzymatic with selectivity Prelog. To 2-bromo-1-phenylethanone (2) was biotransformaded by the fungus $A$. sydowii Ce19 you correspond composed: (S)-2-bromo-1-phenylethanol (2a), (S)-2-cloro-1phenylethanol (1a), whereas to (2c), 2-chloro-1-phenylethanone (1) and the 2phenyloxirane (2b) were obtained by reactions not enzymatic. To 2-bromo-1-(4bromophenyl)ethanone (3) and to 2-bromo-1-(4-nitrophenyl)ethanone (4) were entirely biodegradadas by the fungus $A$. sydowii Ce19. The reduction biocatalytic of the 1-(2iodophenyl)ethanol (5) and 1-(3-iodophenyl)ethanol (6) with the fungus Trichoderma sp Gc1 supplied the 1-(2-iodophenyl)ethanol (5a) and the 1-(3-iodophenyl)ethanol (6a) with excellent excesses enantiomeric (e.e. $>99 \%$ ). It stayed verified also that the fungi derived little seas for promote the reactions of reduction by biocatalysis are going to be cultivated in water of the artificial sea. 
ANEXOS 
SEÇÃO A: Espectros de RMN ${ }^{1} \mathrm{H},{ }^{13} \mathrm{C}$ e IV para os dióis racêmicos 1a - 5a

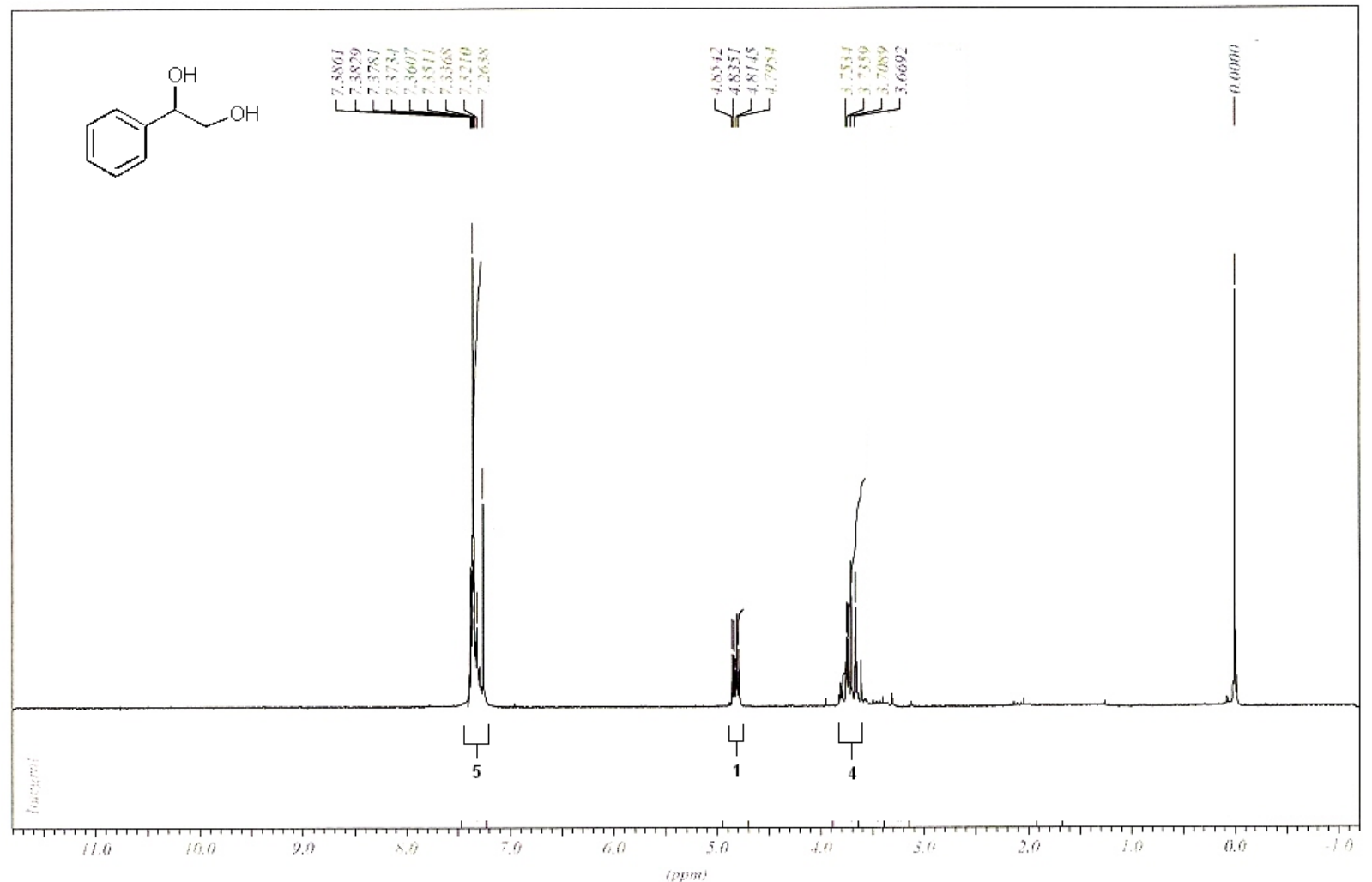

Espectro de RMN ${ }^{1} \mathrm{H}$ do composto 1 a em $\mathrm{CDCl}_{3}$ a $200 \mathrm{MHz}$

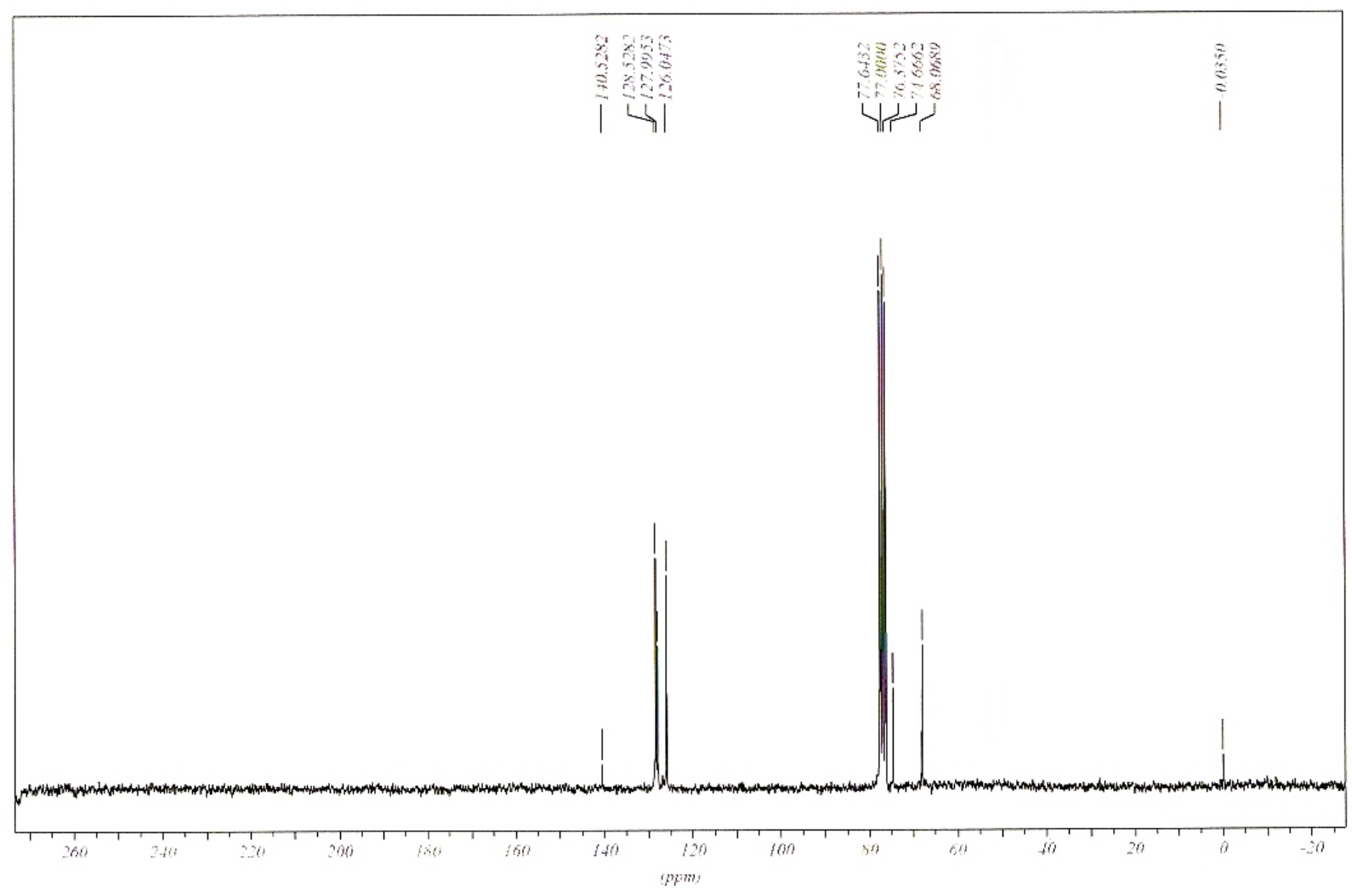

Espectro de RMN ${ }^{13} \mathrm{C}$ do composto $1 \mathrm{a}$ em $\mathrm{CDCl}_{3}$ a $50 \mathrm{MHz}$ 


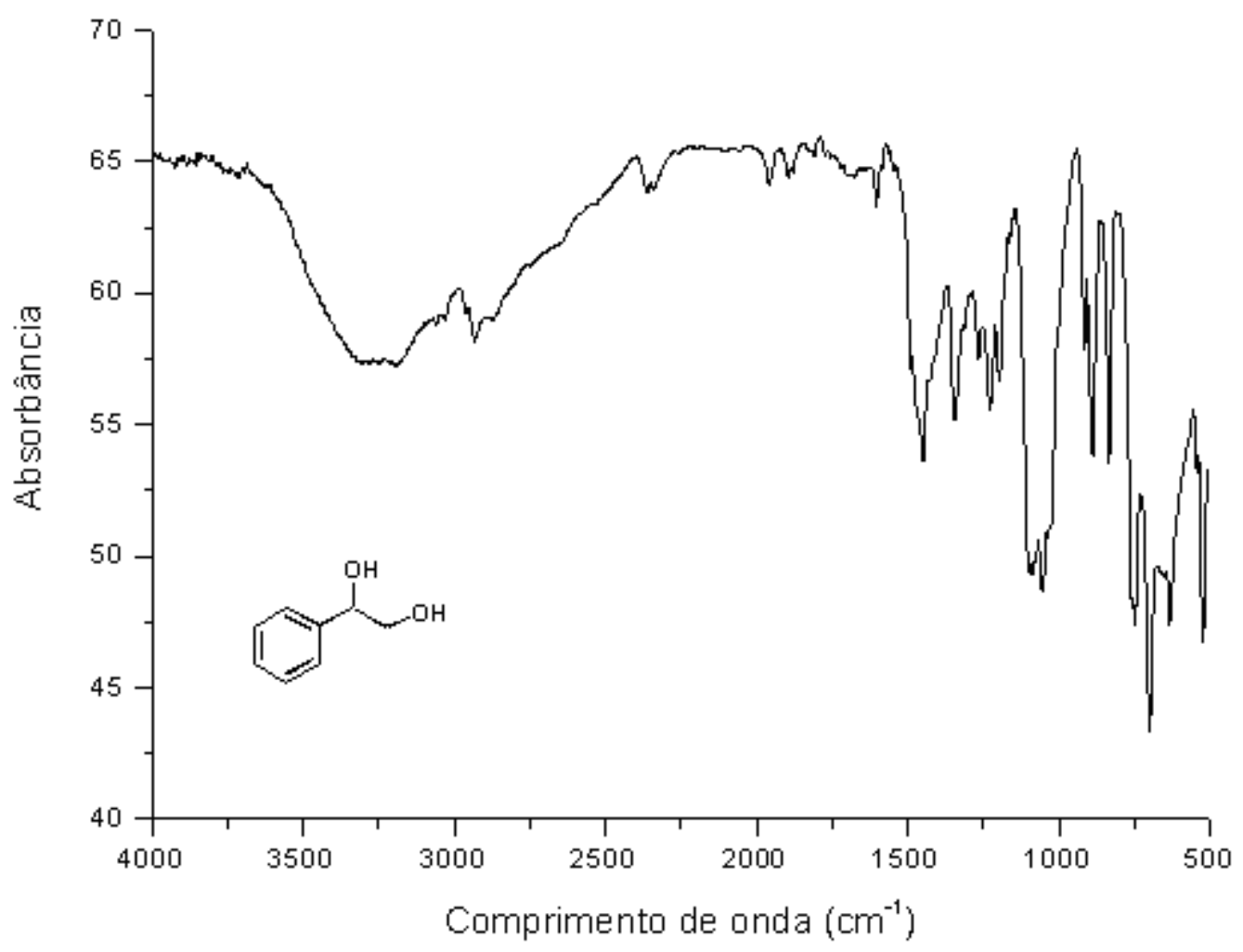

Espectro de IV do composto 1a 


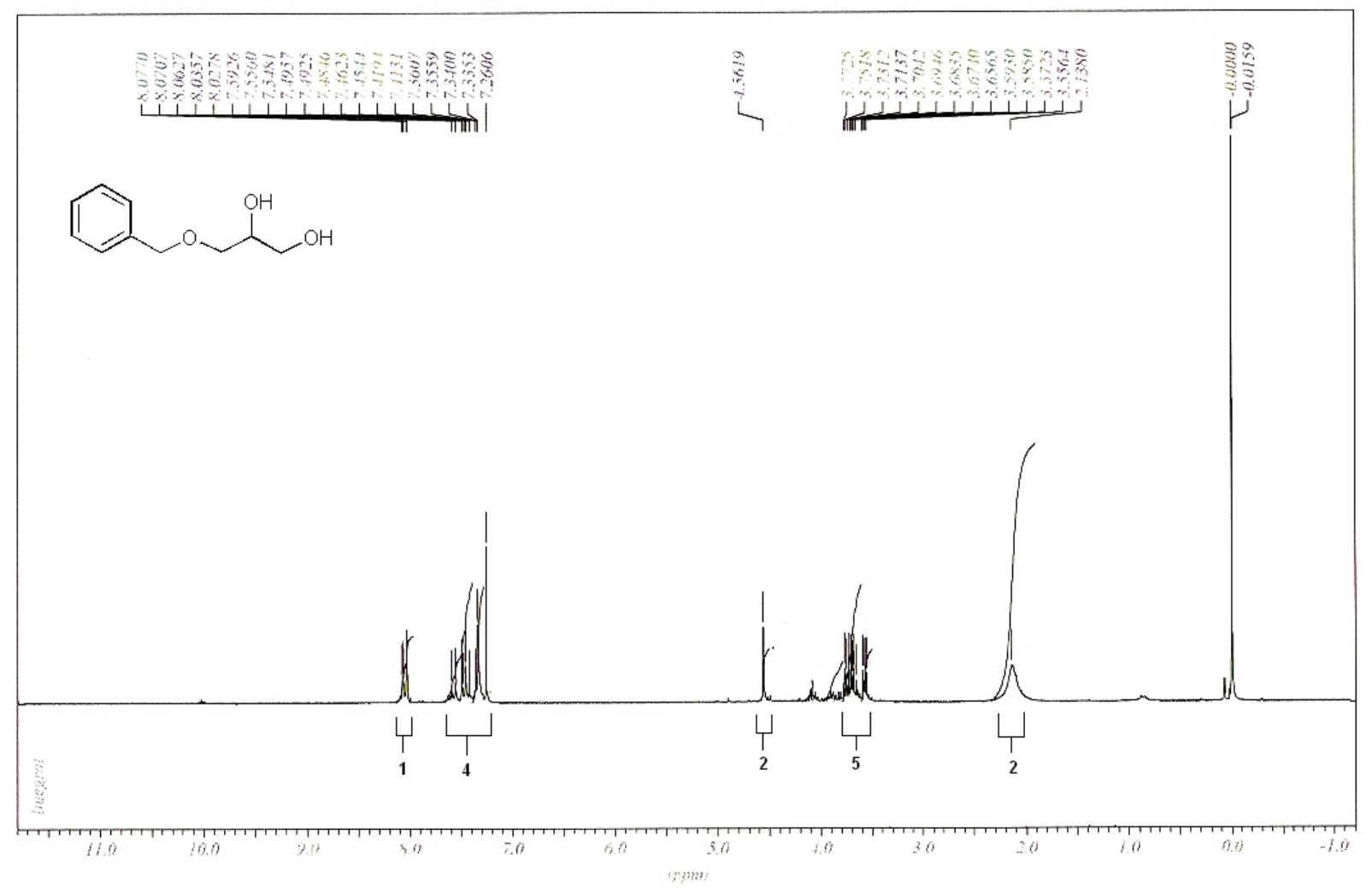

Espectro de RMN ${ }^{1} \mathrm{H}$ do composto $\mathbf{2 a}$ em $\mathrm{CDCl}_{3}$ a $200 \mathrm{MHz}$

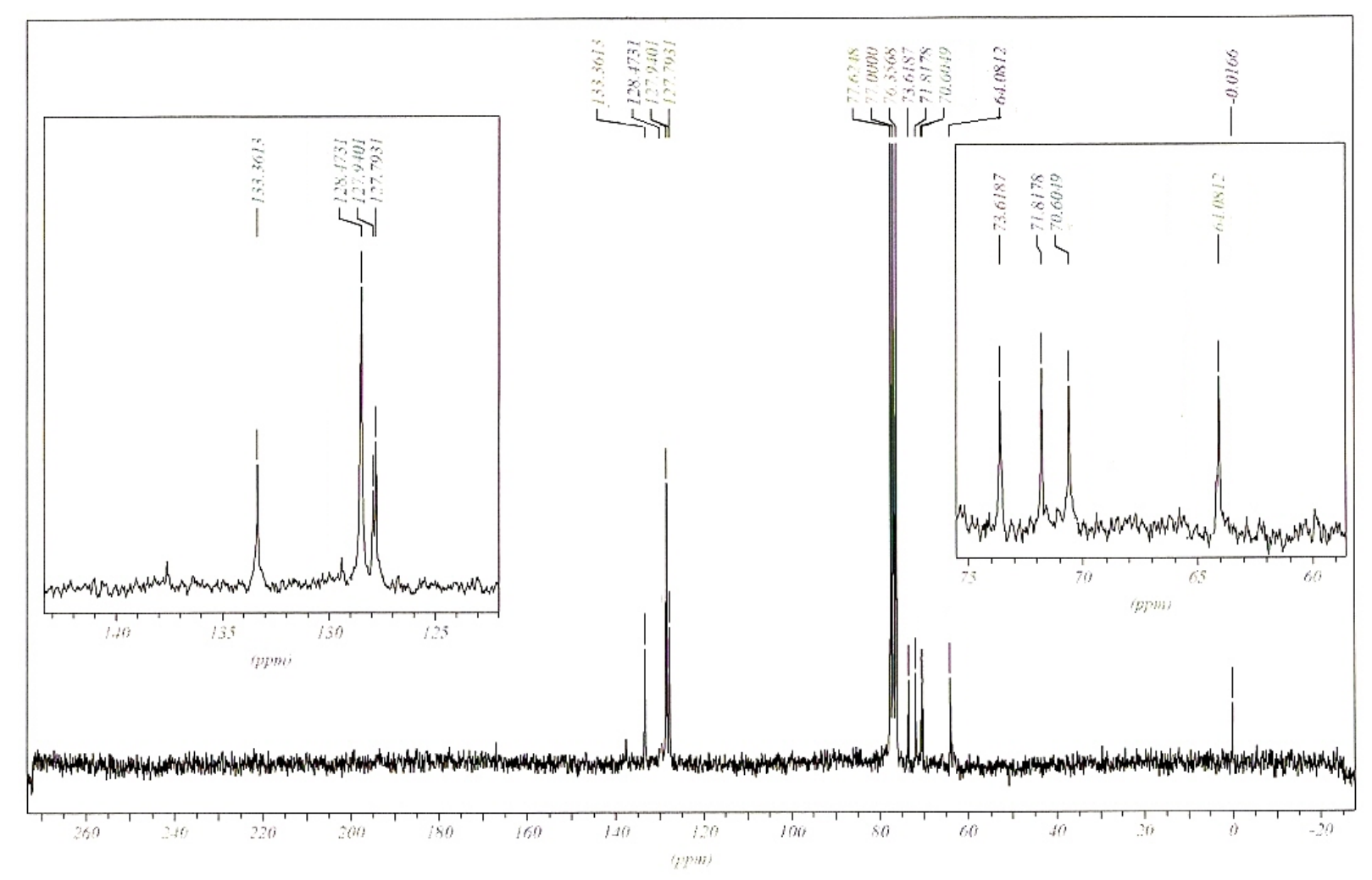

Espectro de RMN ${ }^{13} \mathrm{C}$ do composto $2 \mathbf{a}$ em $\mathrm{CDCl}_{3}$ a $50 \mathrm{MHz}$ 


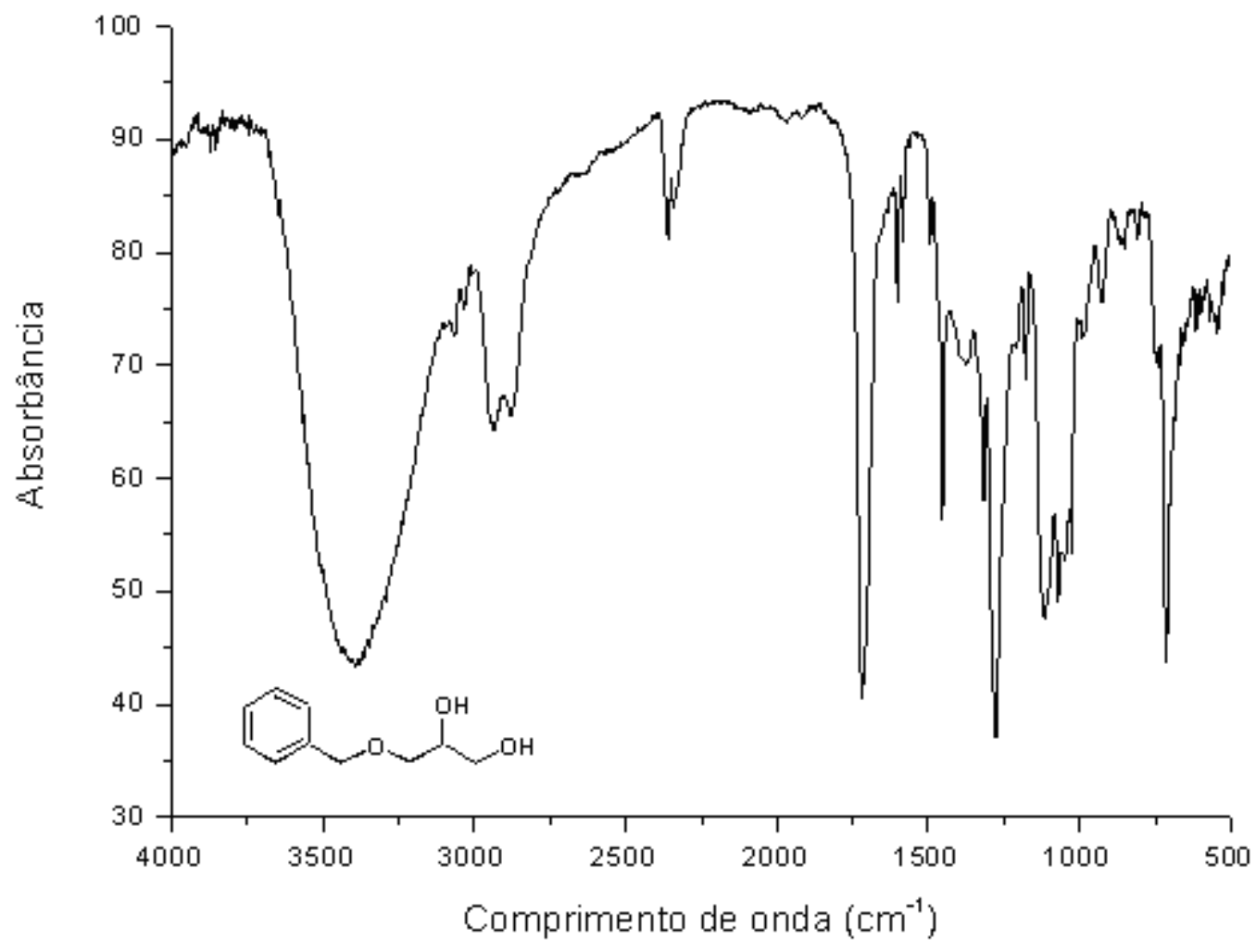

Espectro de IV do composto $\mathbf{2 a}$ 


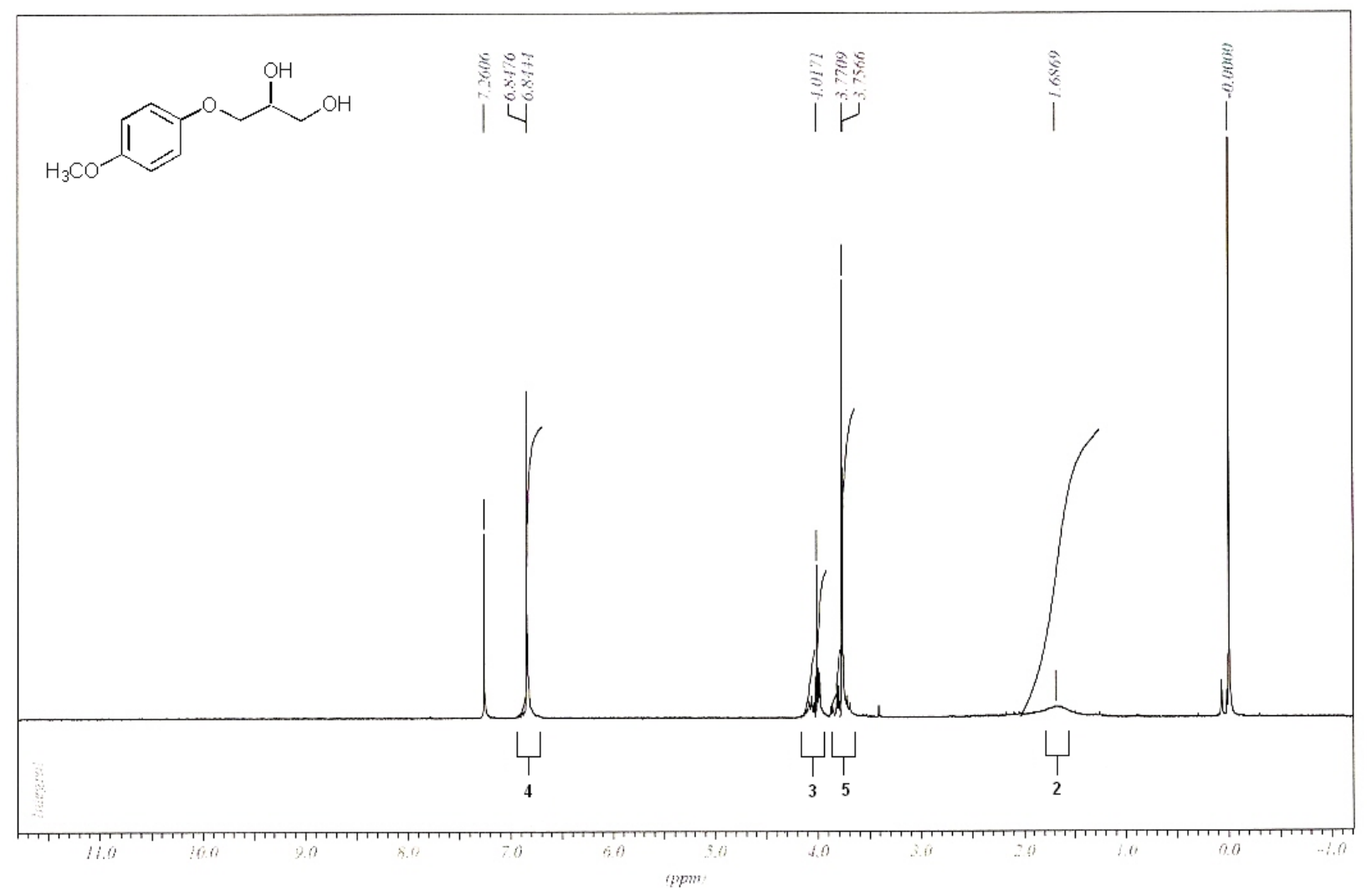

Espectro de RMN ${ }^{1} \mathrm{H}$ do composto $3 \mathbf{a}$ em $\mathrm{CDCl}_{3}$ a $200 \mathrm{MHz}$

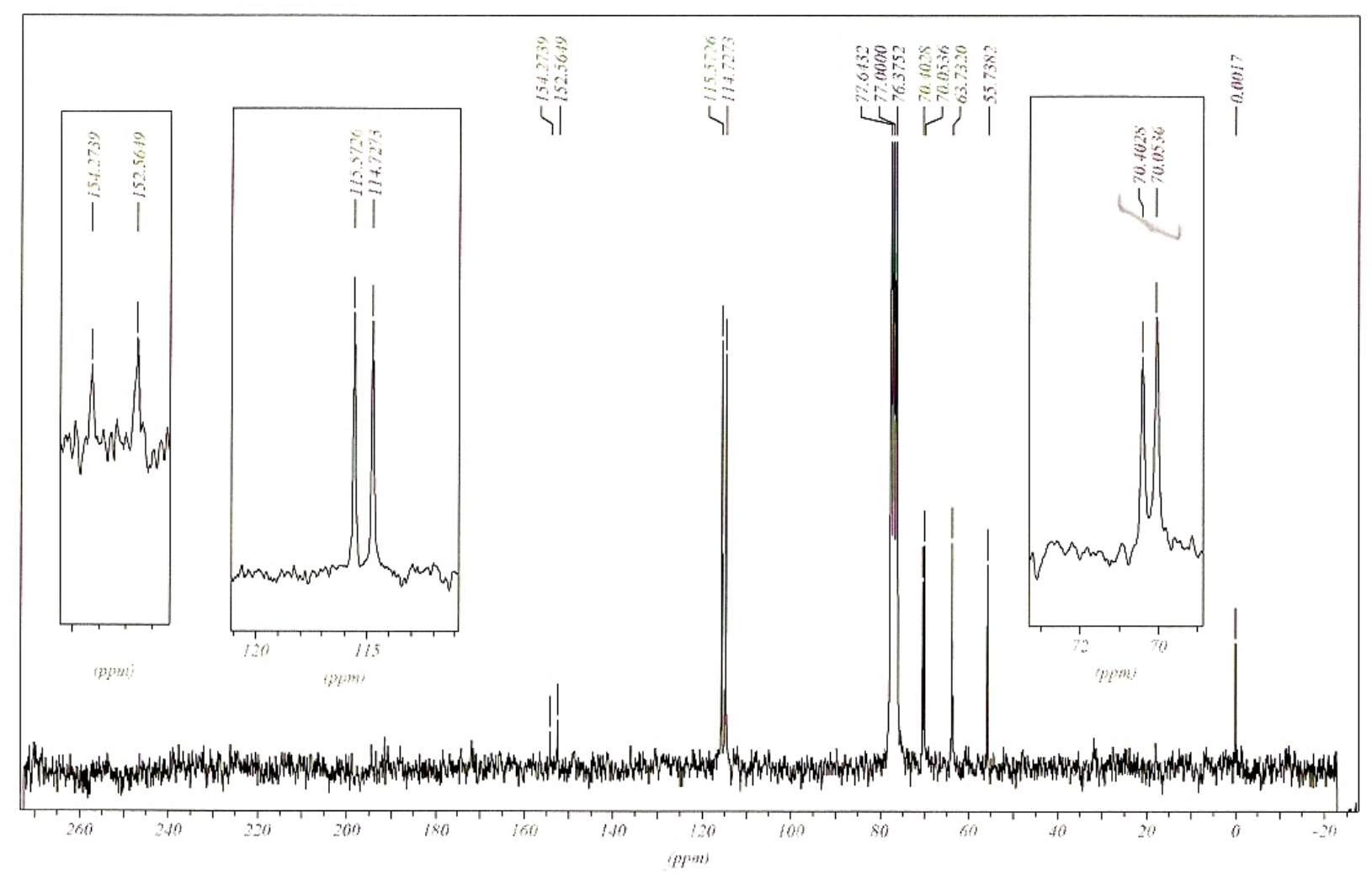

Espectro de RMN ${ }^{13} \mathrm{C}$ do composto $\mathbf{3 a}$ em $\mathrm{CDCl}_{3}$ a $50 \mathrm{MHz}$ 


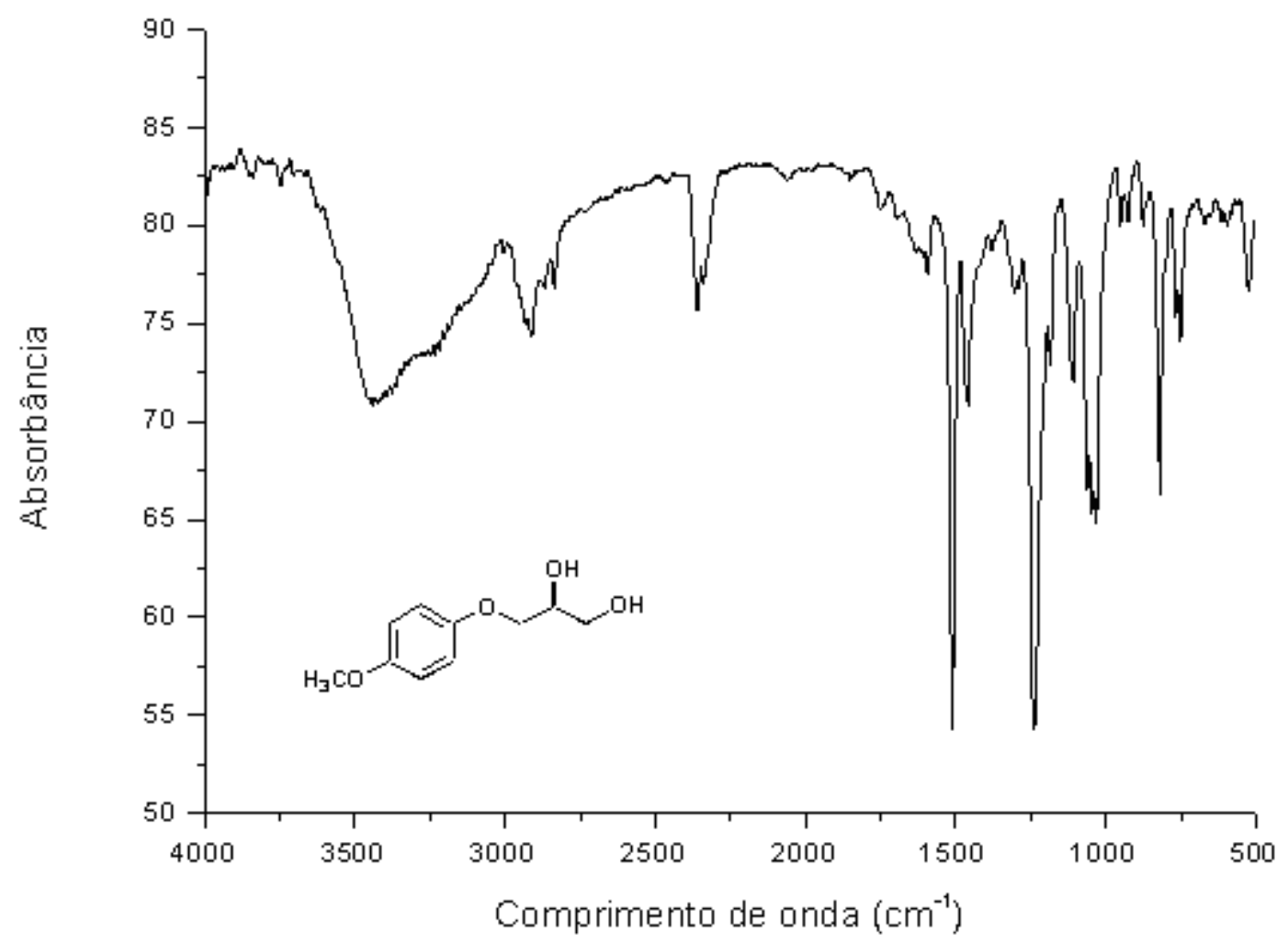

Espectro de IV do composto $\mathbf{3 a}$ 


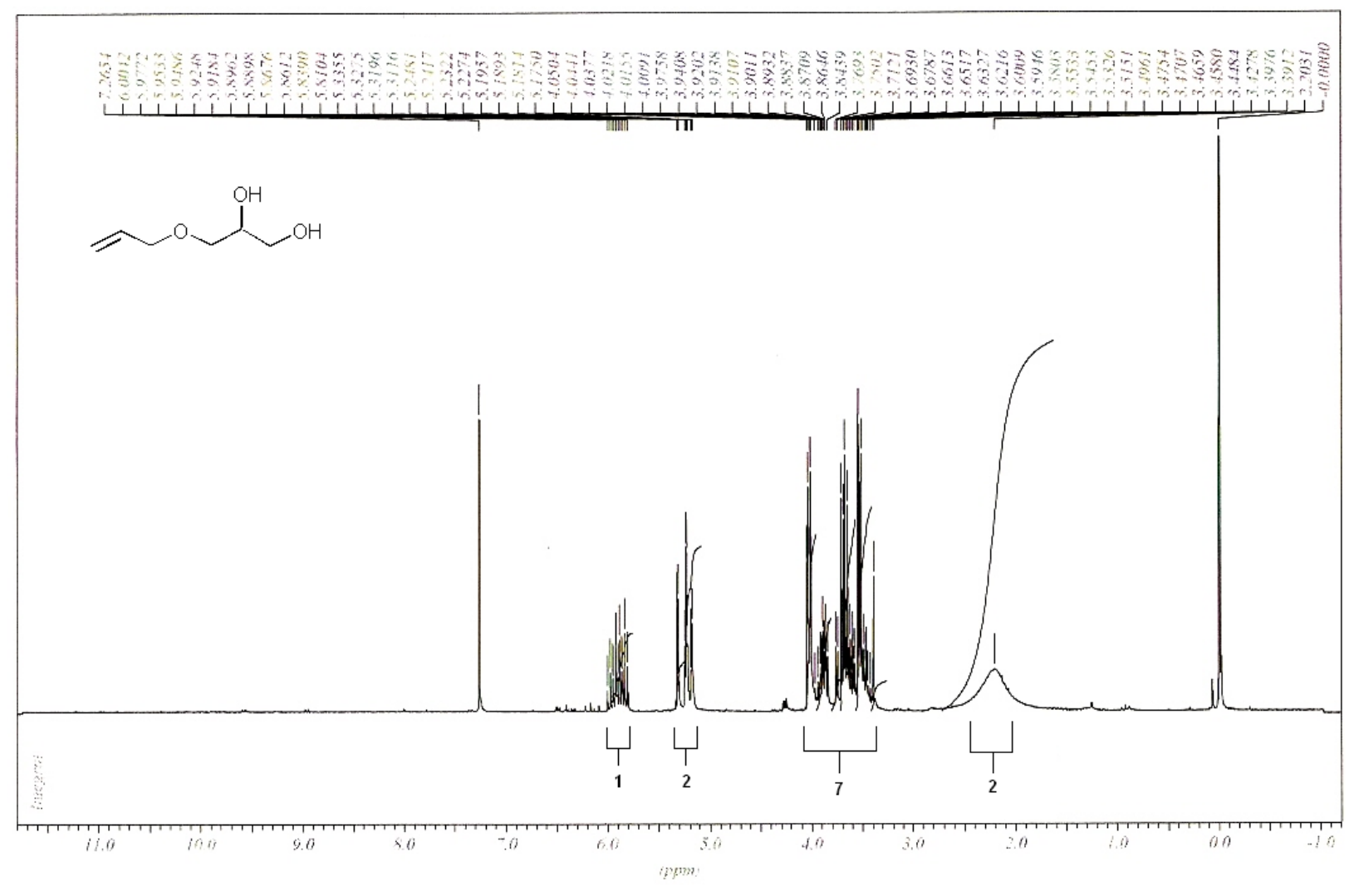

Espectro de RMN ${ }^{1} \mathrm{H}$ do composto $4 \mathrm{a}$ em $\mathrm{CDCl}_{3}$ a $200 \mathrm{MHz}$

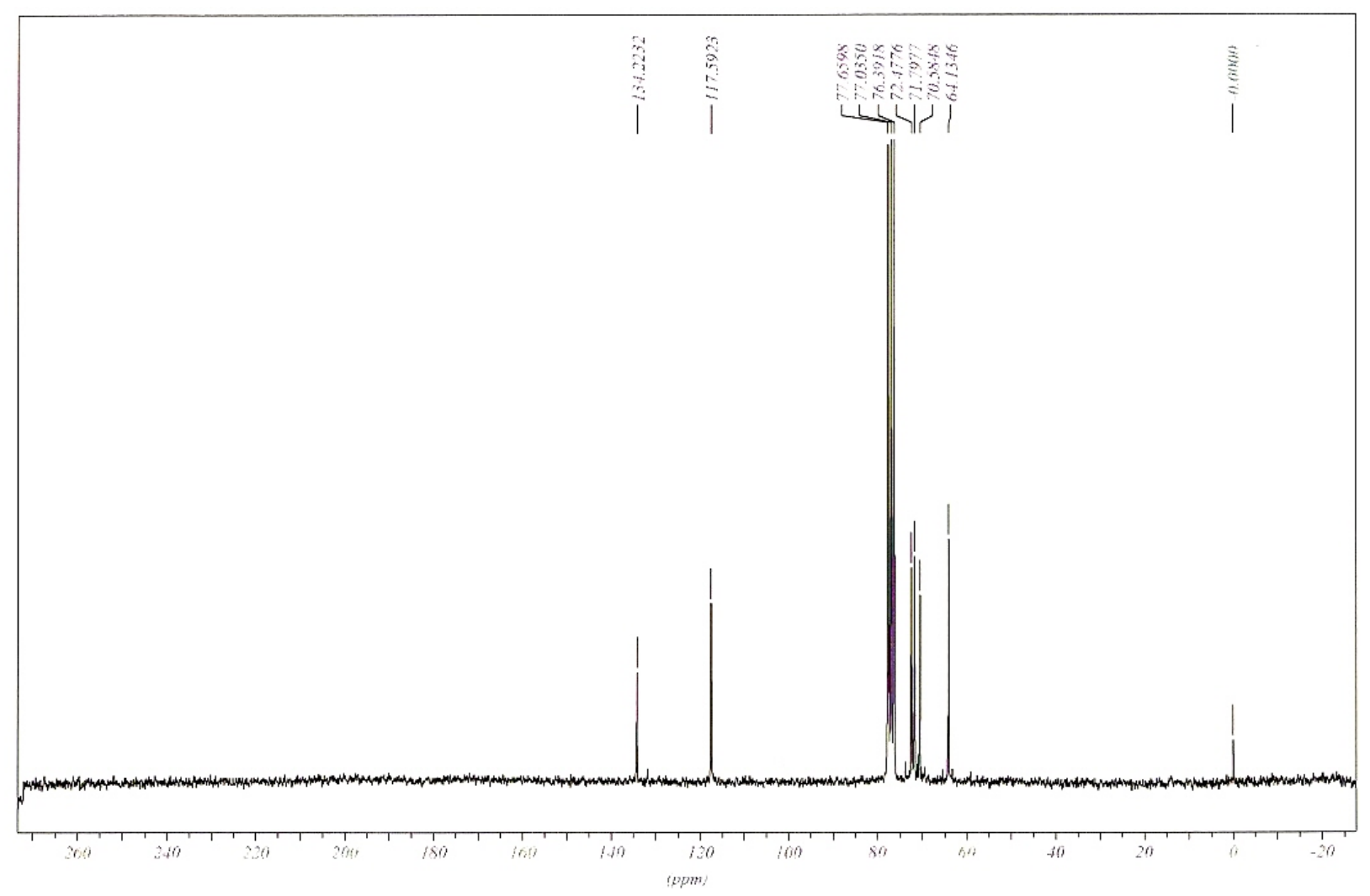

Espectro de RMN ${ }^{13} \mathrm{C}$ do composto $4 a$ em $\mathrm{CDCl}_{3}$ a $50 \mathrm{MHz}$ 


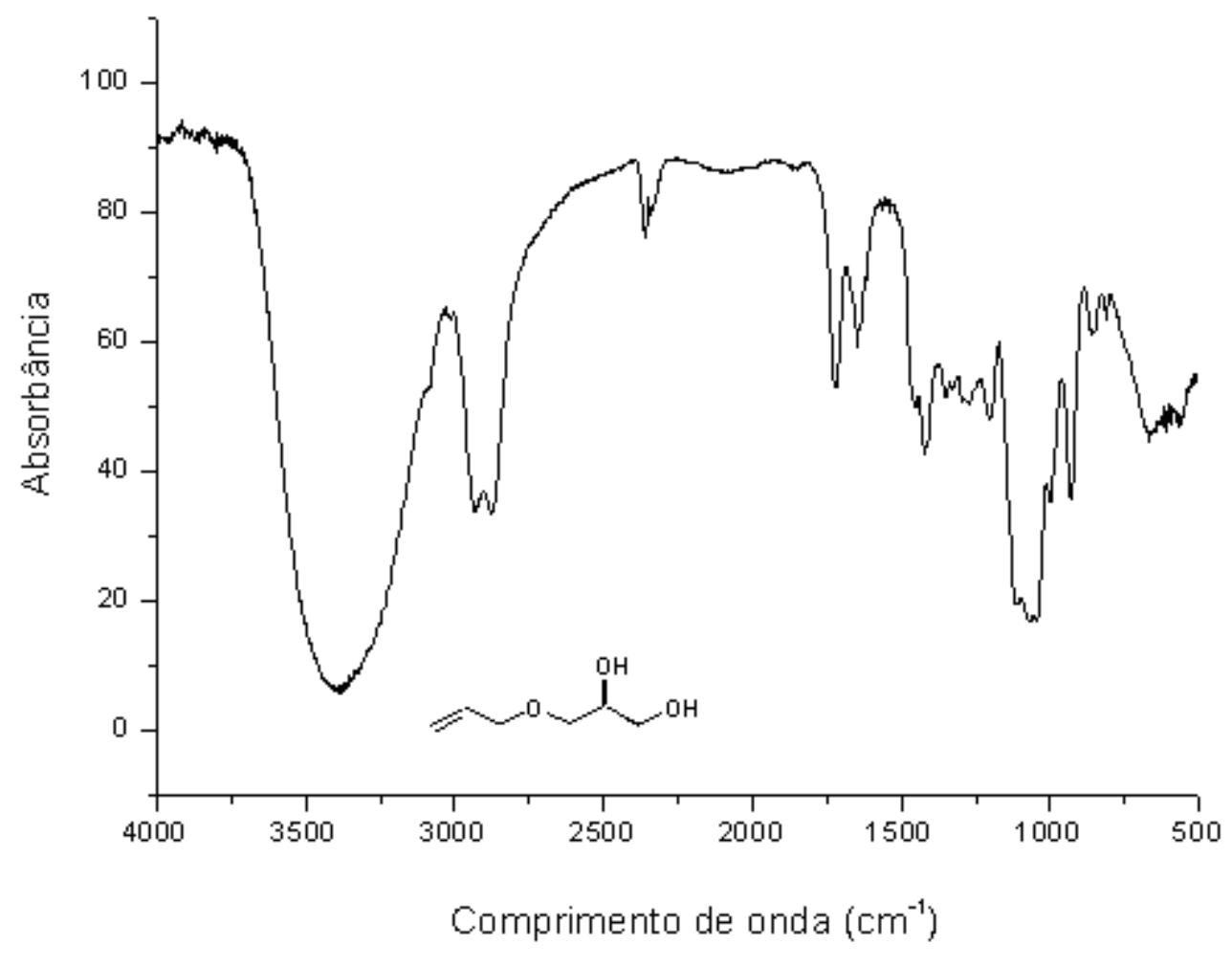

Espectro de IV do composto 4 a 


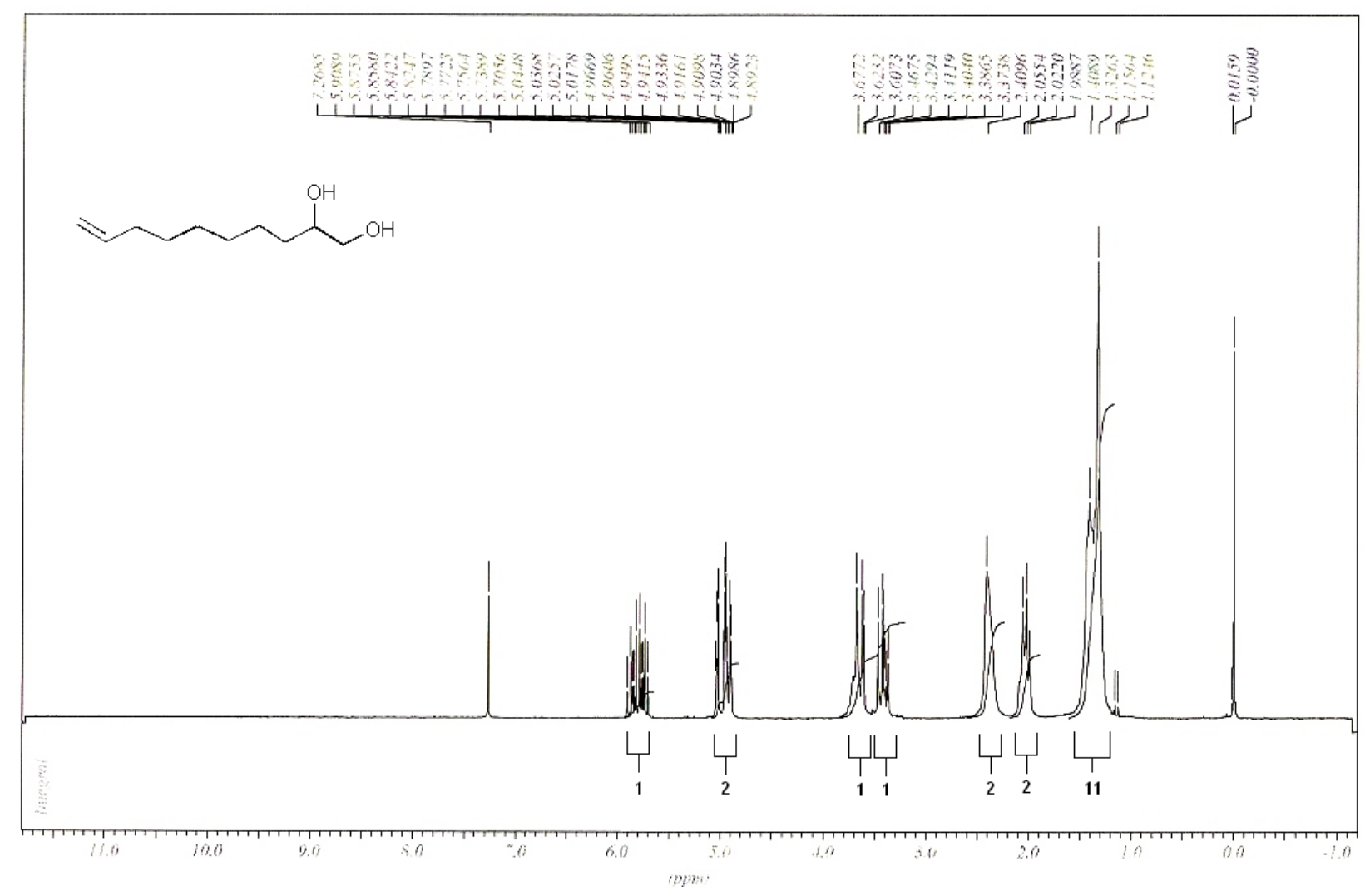

Espectro de RMN ${ }^{1} \mathrm{H}$ do composto $5 \mathrm{a}$ em $\mathrm{CDCl}_{3}$ a $200 \mathrm{MHz}$

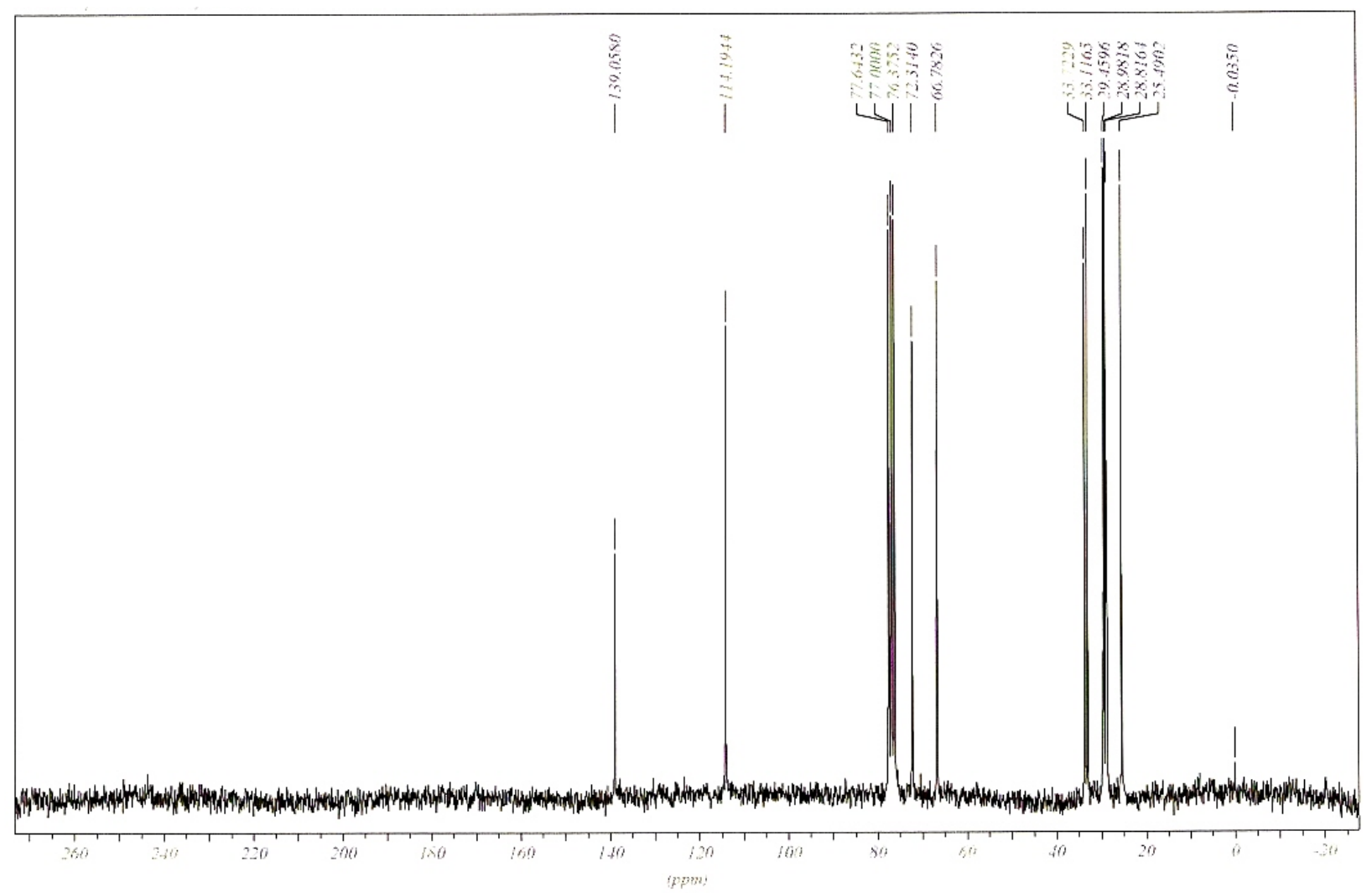

Espectro de RMN ${ }^{13} \mathrm{C}$ do composto $5 \mathrm{a}$ em $\mathrm{CDCl}_{3}$ a $50 \mathrm{MHz}$ 


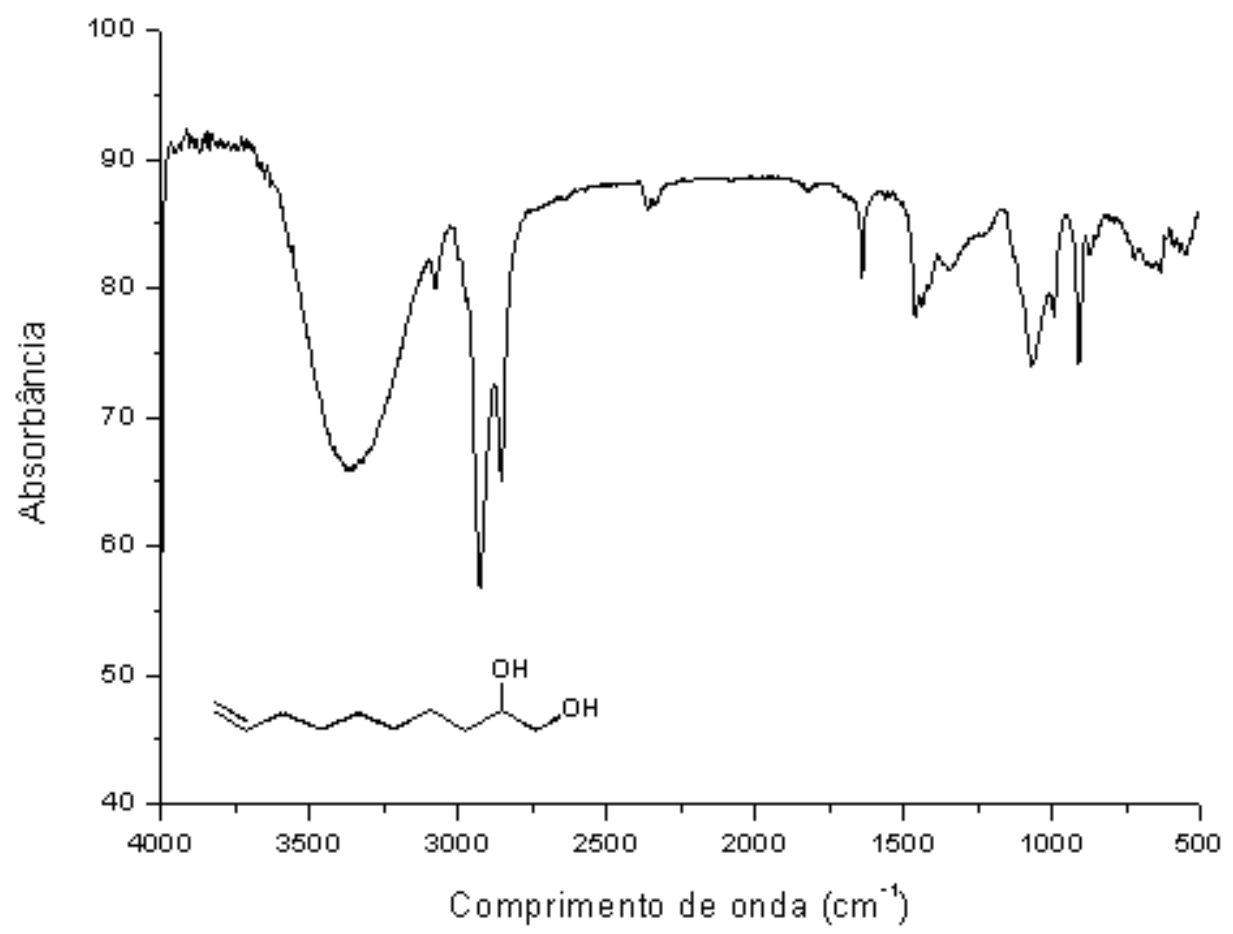

Espectro de IV do composto $\mathbf{5 a}$ 
SEÇÃO B: Espectros de RMN ${ }^{1} \mathrm{H},{ }^{13} \mathrm{C}$ e IV para as cloroidrinas $2 \mathrm{~b}$, 3b e 4b

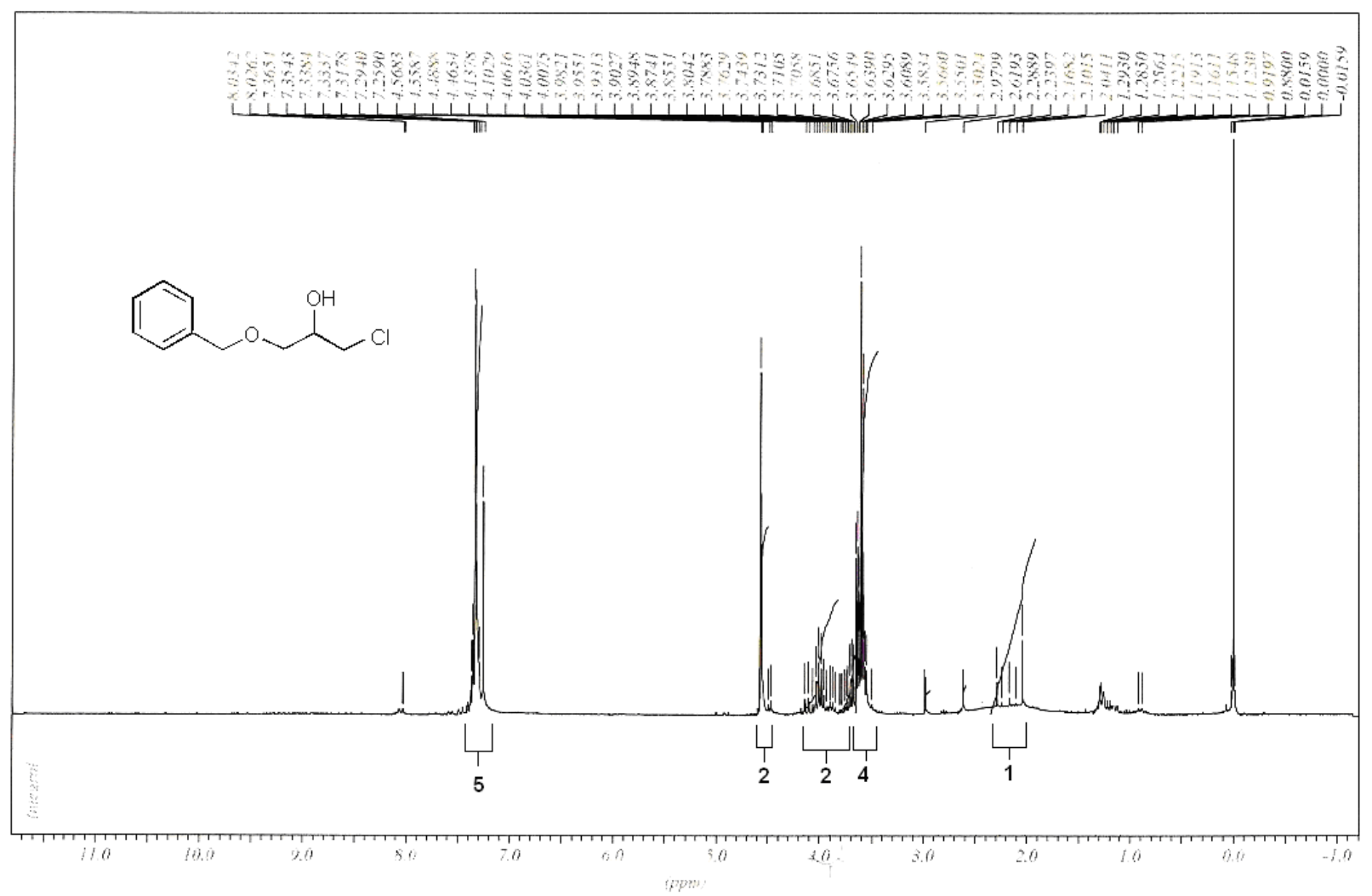

Espectro de RMN ${ }^{1} \mathrm{H}$ do composto $\mathbf{2} \mathbf{b}$ em $\mathrm{CDCl}_{3}$ a $200 \mathrm{MHz}$

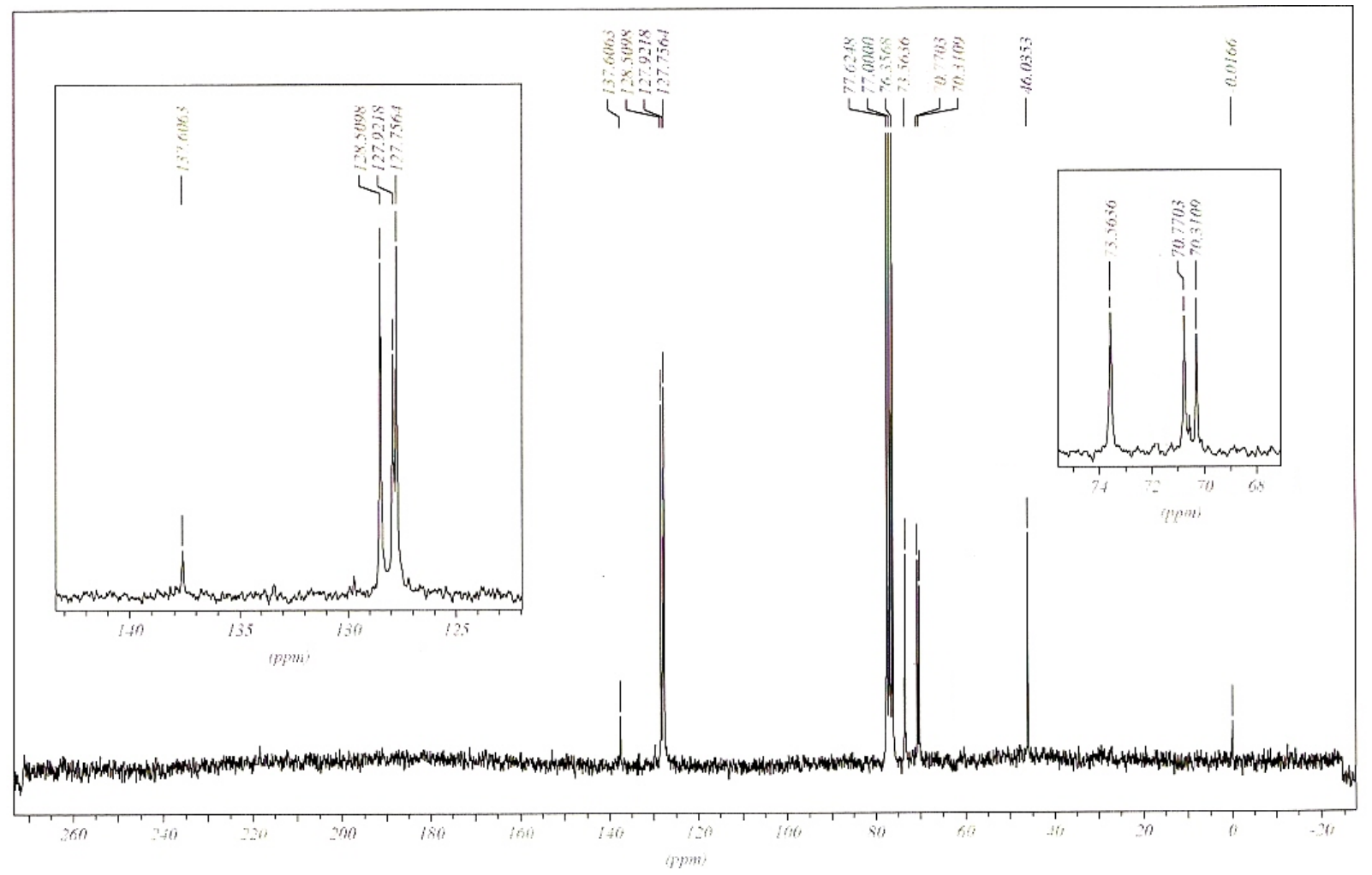

Espectro de RMN ${ }^{13} \mathrm{C}$ do composto $\mathbf{2 b}$ em $\mathrm{CDCl}_{3}$ a $50 \mathrm{MHz}$ 


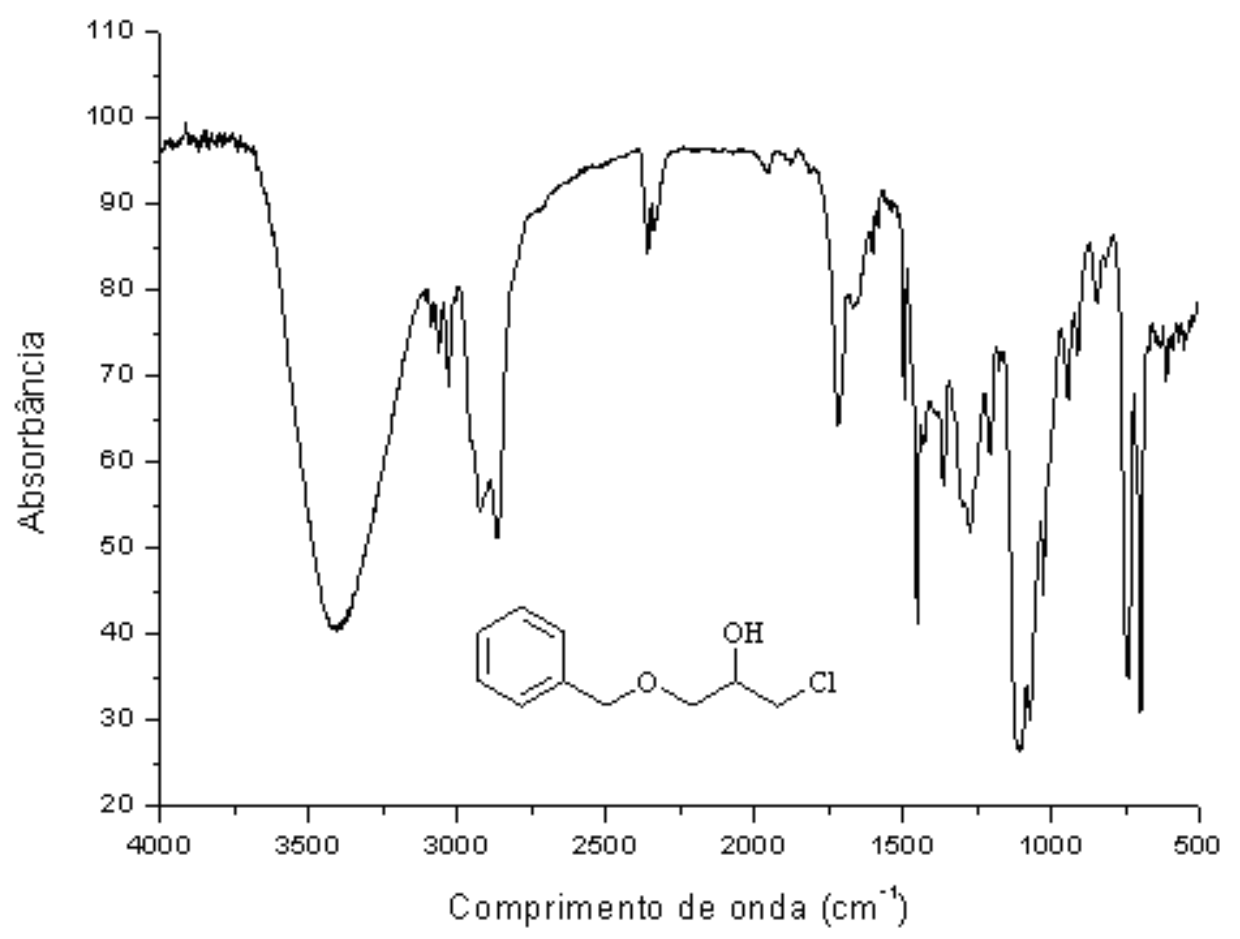

Espectro de IV do composto $\mathbf{2 b}$ 


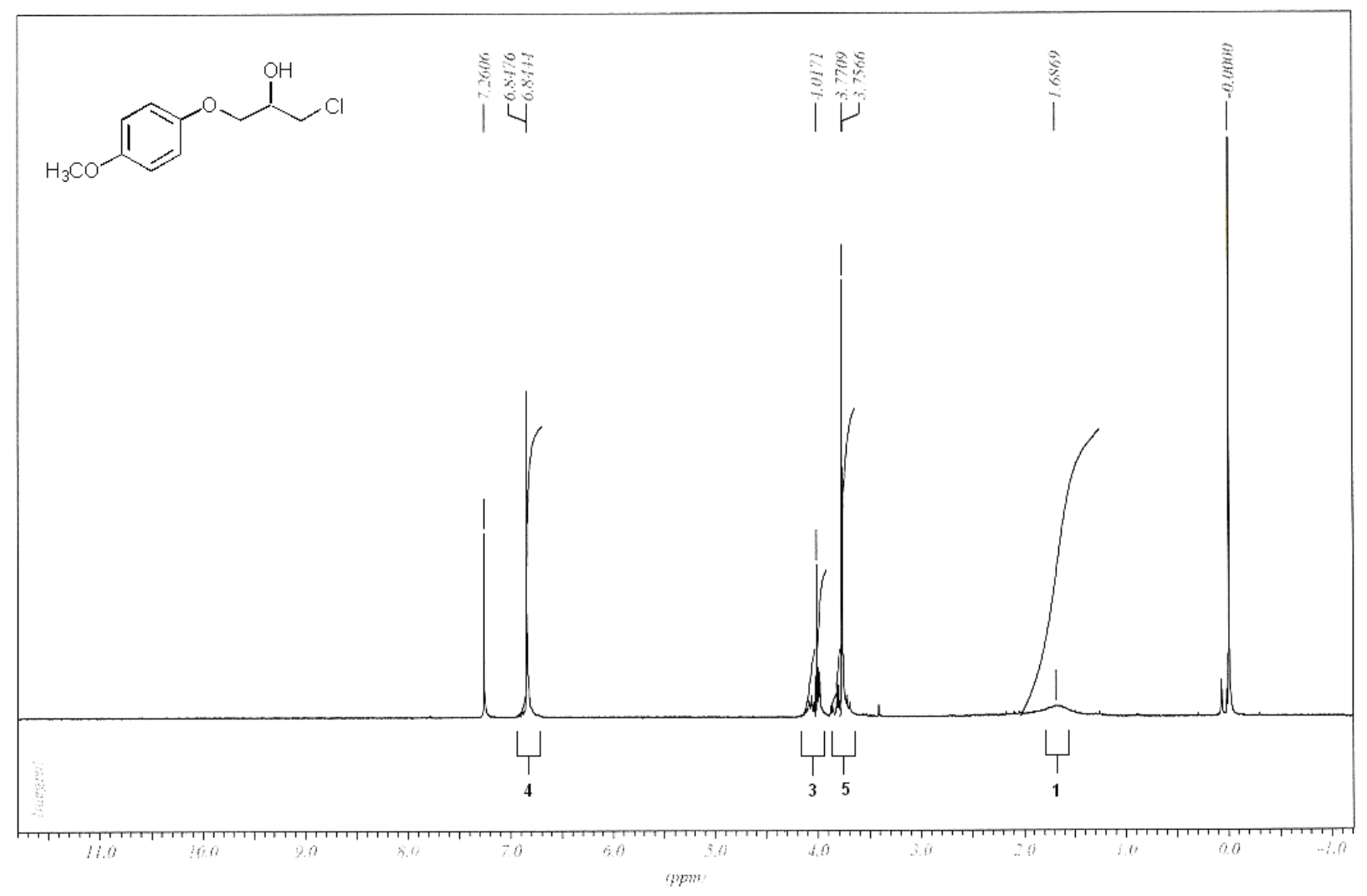

Espectro de RMN ${ }^{1} \mathrm{H}$ do composto $\mathbf{3 b}$ em $\mathrm{CDCl}_{3}$ a $200 \mathrm{MHz}$

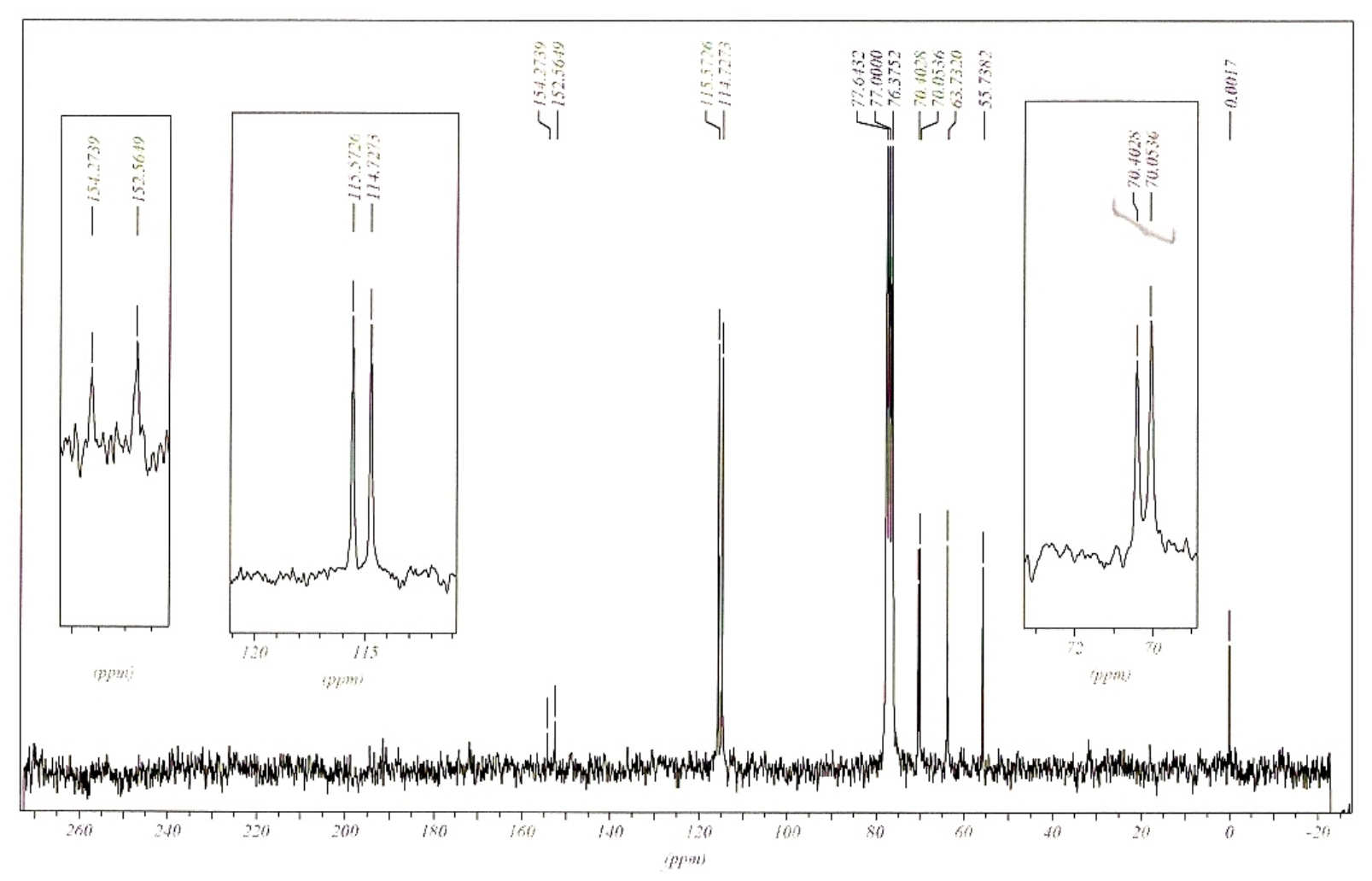

Espectro de $\mathrm{RMN}{ }^{13} \mathrm{C}$ do composto $\mathbf{3 b}$ em $\mathrm{CDCl}_{3}$ a $50 \mathrm{MHz}$ 


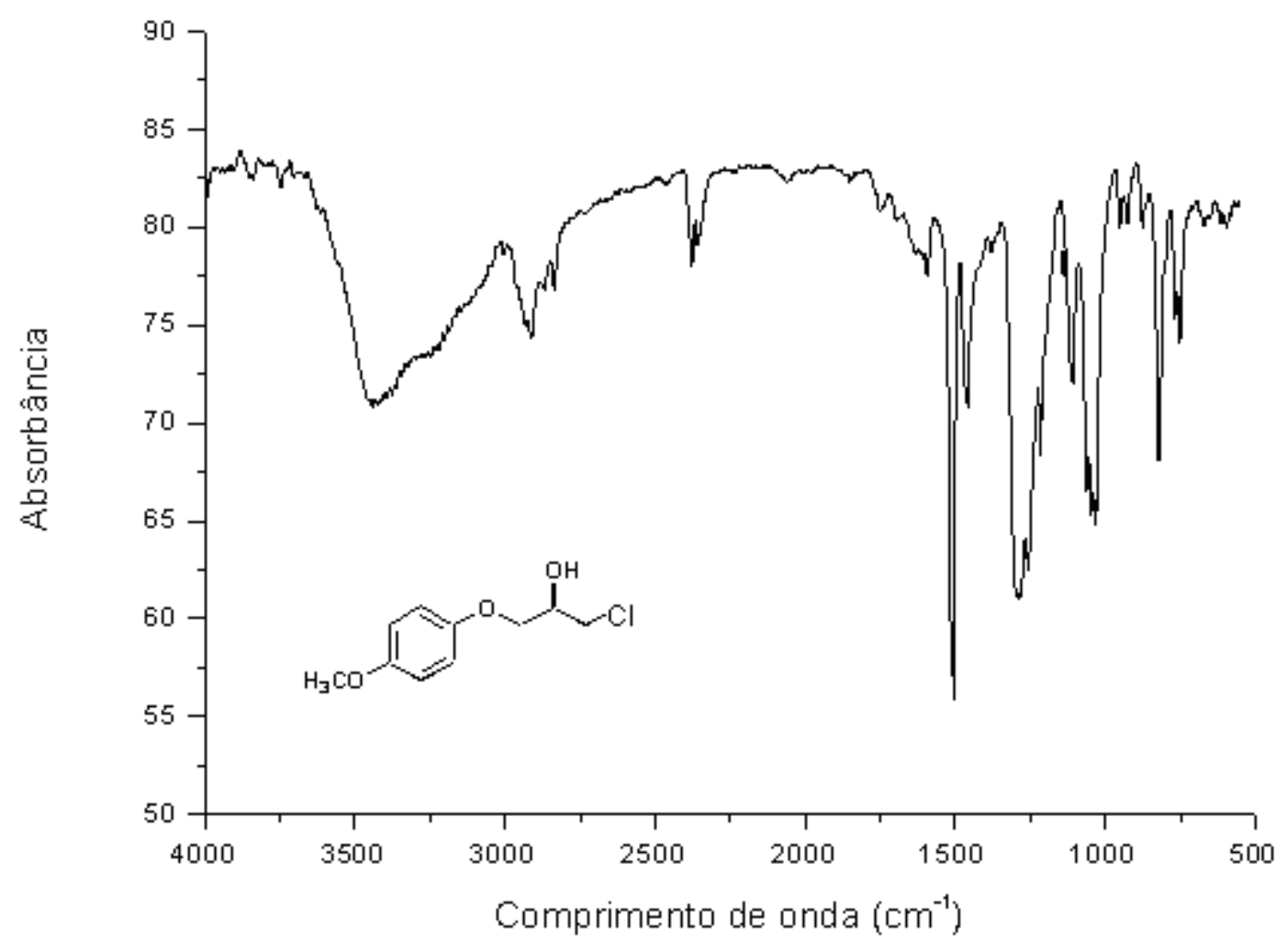

Espectro de IV do composto $\mathbf{3 b}$ 


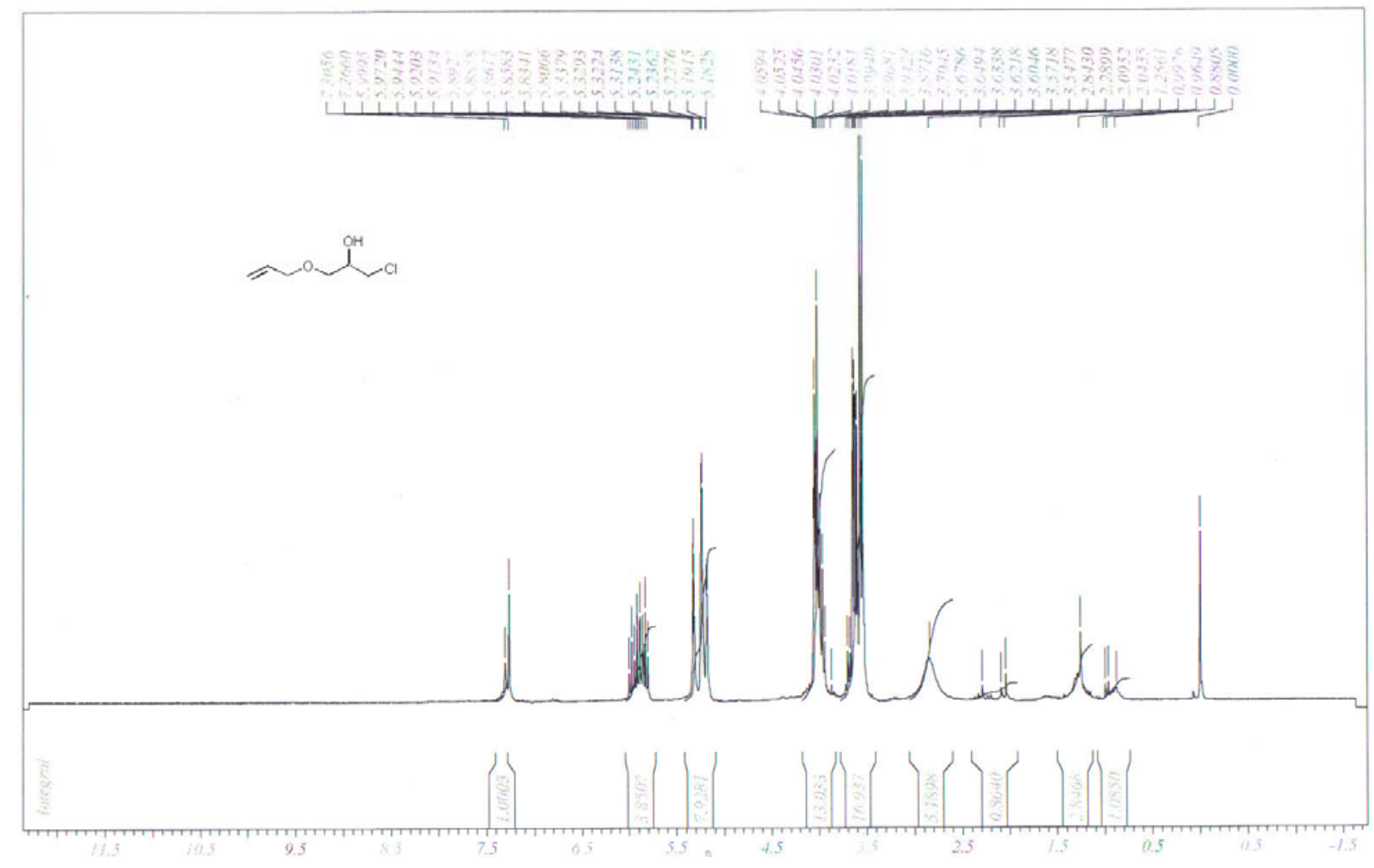

Espectro de RMN ${ }^{1} \mathrm{H}$ do composto $4 \mathbf{b}$ em $\mathrm{CDCl}_{3}$ a $200 \mathrm{MHz}$

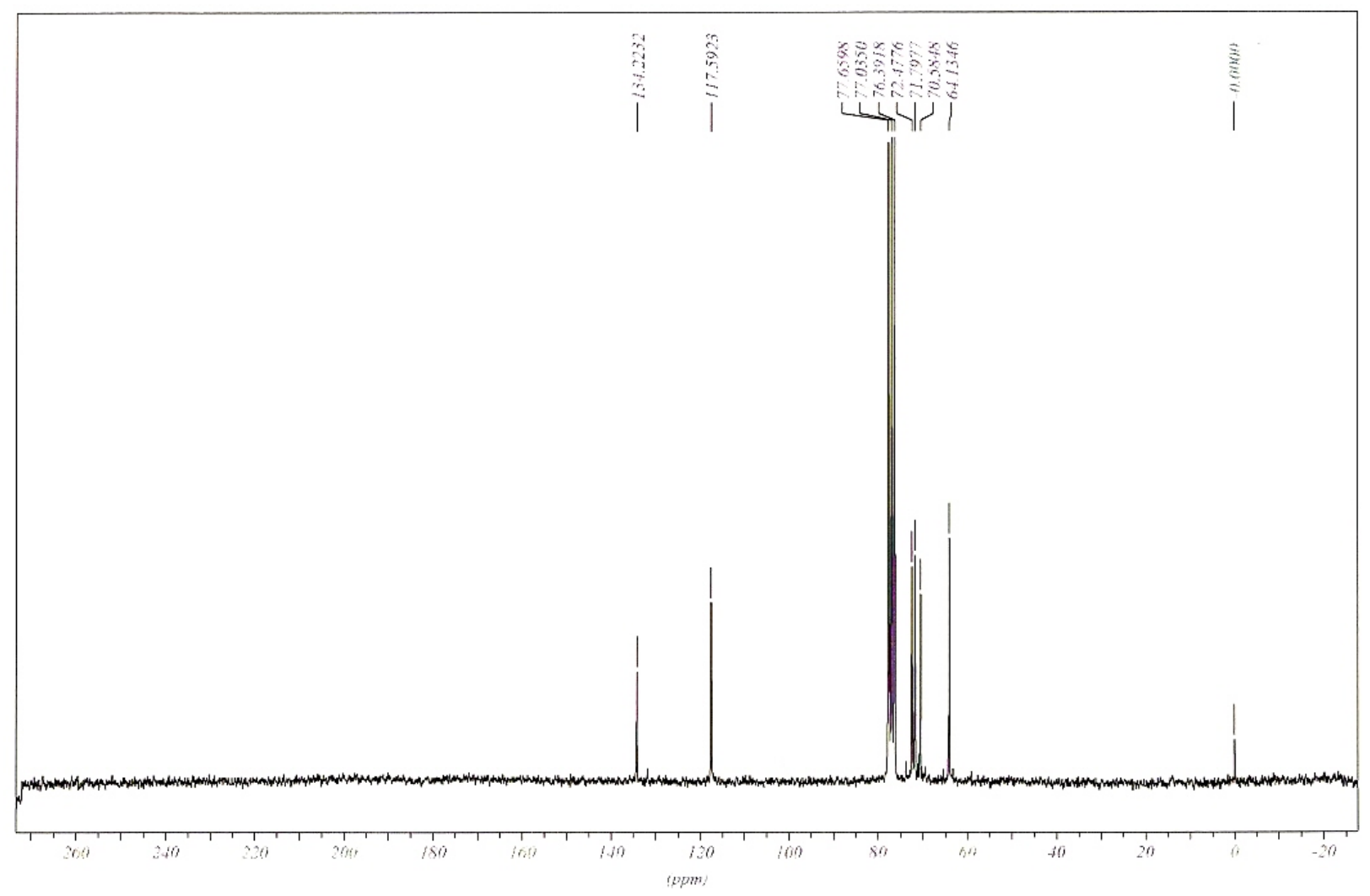

Espectro de $\mathrm{RMN}{ }^{13} \mathrm{C}$ do composto $4 \mathrm{~b}$ em $\mathrm{CDCl}_{3}$ a $50 \mathrm{MHz}$ 


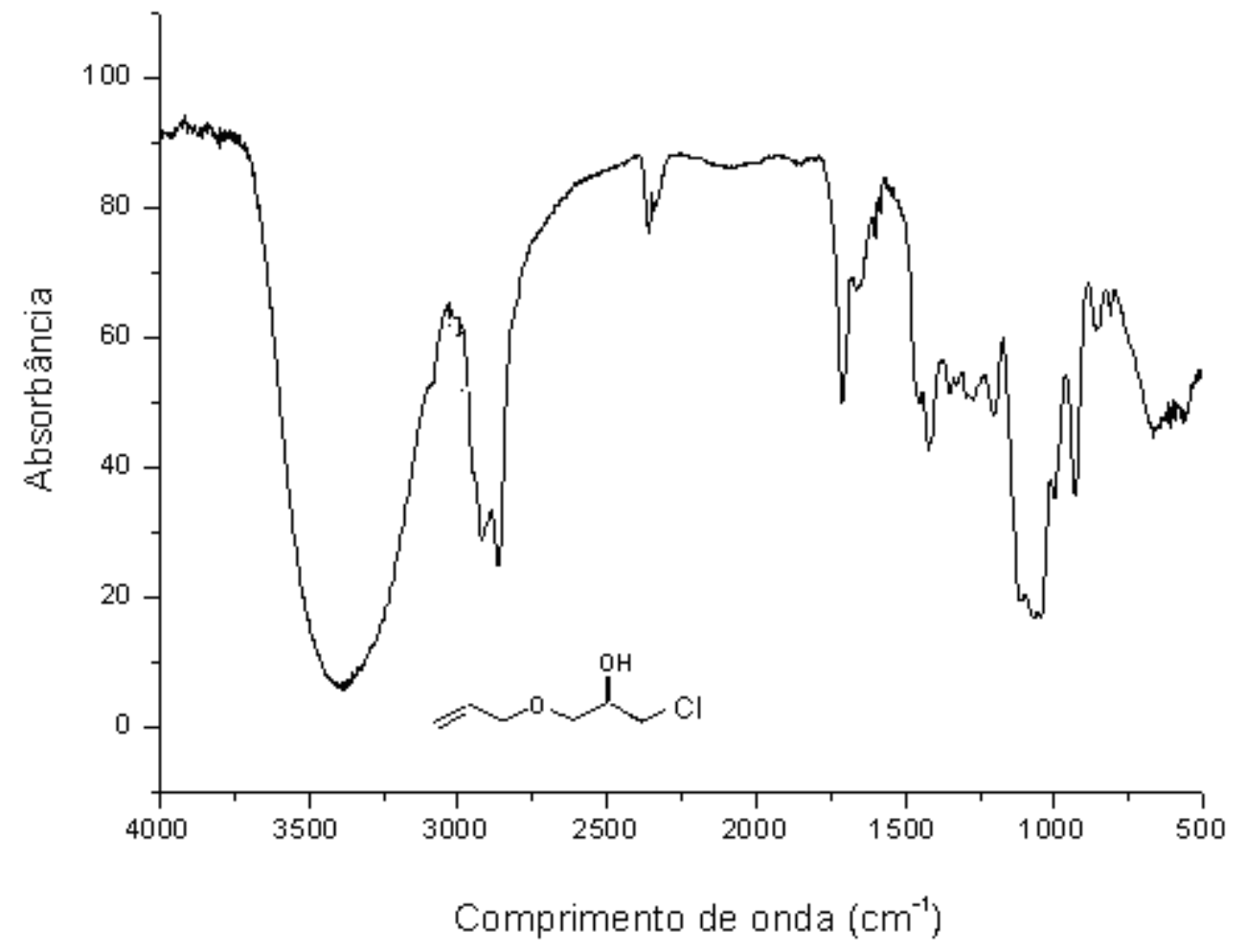

Espectro de IV do composto $4 \mathbf{b}$ 
SEÇÃO C: Espectro de RMN ${ }^{1} \mathrm{H}$ para o acetato 4c

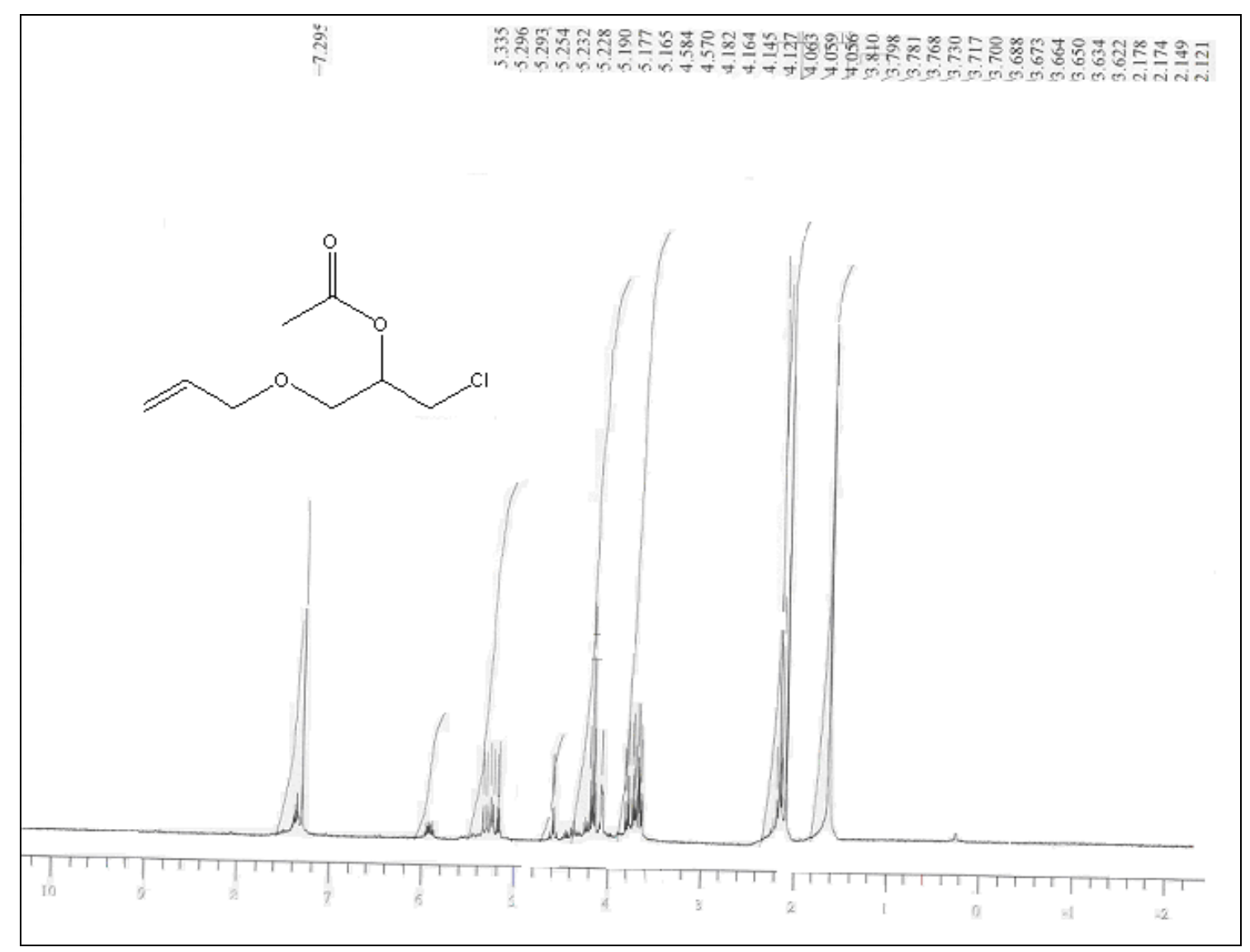

Espectro de RMN ${ }^{1} \mathrm{H}$ do composto $4 \mathrm{c}$ em $\mathrm{CDCl}_{3}$ a $200 \mathrm{MHz}$ 


\section{INTRODUÇÃO}

\section{1- Química verde}

A química tem uma grande participação nos dias atuais com os inúmeros produtos fundamentais à humanidade, desde diversos combustíveis aos mais complexos medicamentos. No entanto, a produção química também gera inúmeros inconvenientes, como a formação de subprodutos tóxicos e a contaminação do ambiente e do próprio homem expostos a esses xenobióticos. A preocupação com esses impasses pode ser claramente observada, nos últimos anos, com o crescimento contínuo da pressão sobre as indústrias químicas, tanto através da sociedade civil, como das autoridades governamentais e acadêmicas, no sentido de aprimorar o desenvolvimento de processos que sejam cada vez menos prejudiciais ao meio ambiente. [1]

Dentro dos princípios de desenvolvimento sustentável, tem-se que a química deve manter e melhorar a qualidade de vida. O grande desafio é a continuidade do desenvolvimento, diminuindo os danos causados ao meio ambiente. Esse novo caminho a ser delineado pela química é denominado como química sustentável ou química verde. Além dos benefícios ambientais, desenvolvendo tecnologias e processos incapazes de causar poluição, a química verde apresenta também um impacto econômico graças à diminuição de gastos com o armazenamento e tratamento de resíduos, à descontaminação e ao pagamento de indenizações. [1]

O primeiro desafio é a conscientização do desenvolvimento de tecnologias limpas no lugar das atuais. As iniciativas da química verde englobam todas as áreas da ciência, sempre considerando os princípios de sustentabilidade, como: i) uso de reagentes alternativos e renováveis, ao invés de reagentes tóxicos e não-biodegradáveis; ii) a mudança de solventes tóxicos por outros alternativos; iii) melhoramento dos processos naturais, como biossínteses e 
biocatálises; iv) desenvolvimento de compostos seguros (com baixa toxicidade); v) desenvolvimento de condições reacionais para se obter maior rendimento e menor geração de subprodutos e, por final, vi) na minimização do consumo de energia. [2]

Uma área de estudo em expansão é a produção de biocatalisadores, devido à sua grande diversidade, à disponibilidade de técnicas modernas para seu aproveitamento e, sobretudo, à sua viabilidade econômica e redução do impacto ambiental, resultante da sua utilização.

\section{2- Biocatalisadores}

O termo biocatálise abrange os processos em que um catalisador biológico (enzima) é utilizado para a conversão de um substrato (composto orgânico) em um produto de interesse, por um número limitado de etapas enzimáticas. [3]

As enzimas são proteínas de grande complexidade estrutural, que atuam como catalisadores de reações químicas do metabolismo celular. São constituídas por resíduos de aminoácidos, unidos por ligações peptídicas e possuem massa molar que varia de milhares a milhões de Daltons (1 Da = g/mol), Figura 1 .

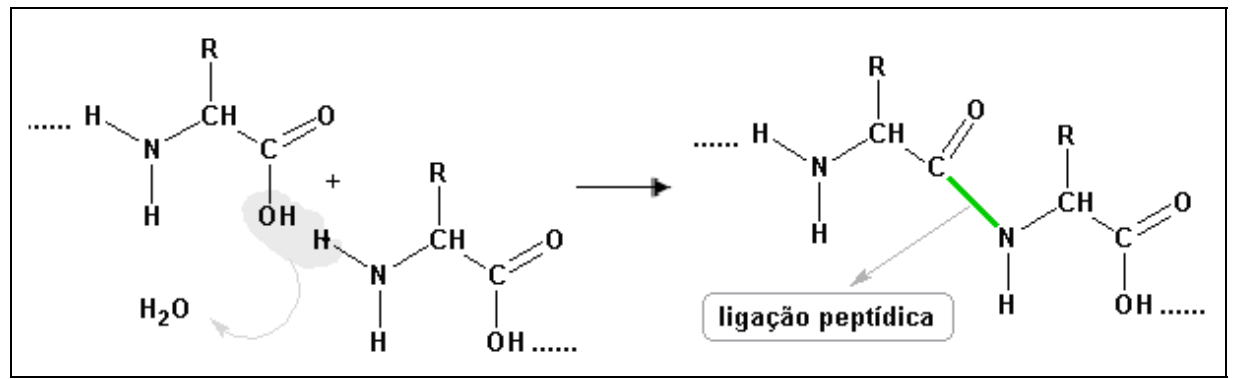

Figura 1. Formação da ligação peptídica entre dois aminoácidos [6] 
A atividade catalítica de uma enzima varia com diversos fatores, sendo o mais importante a concentração do substrato [S]. A atividade enzimática aumenta com o aumento da [S] até uma concentração de saturação, a partir da qual a velocidade da reação é máxima $\left(\mathrm{V}_{\max }\right)$. Todas as enzimas mostram o efeito de saturação, porém esse varia amplamente em relação à [S] necessária para produzi-lo. O gráfico da velocidade da reação enzimática versus concentração do substrato é uma hipérbole para enzimas que obedecem à lei de Michaelis-Menten, e permite determinar a $[\mathrm{S}]$ correspondente à metade de $\mathrm{V}_{\max }$, denominada $K_{\mathrm{m}}$ (constante de MichaelisMenten). Essa constante expressa a afinidade da enzima pelo substrato, ou seja, quanto menor o valor de $K_{\mathrm{m}}$, maior a afinidade da enzima pelo substrato. O gráfico do inverso da velocidade inicial em função de 1/[S] lineariza a curva, facilitando a determinação de $K_{\mathrm{m}}$ (relação de Lineweaver-Burk), Figura 2. [3]
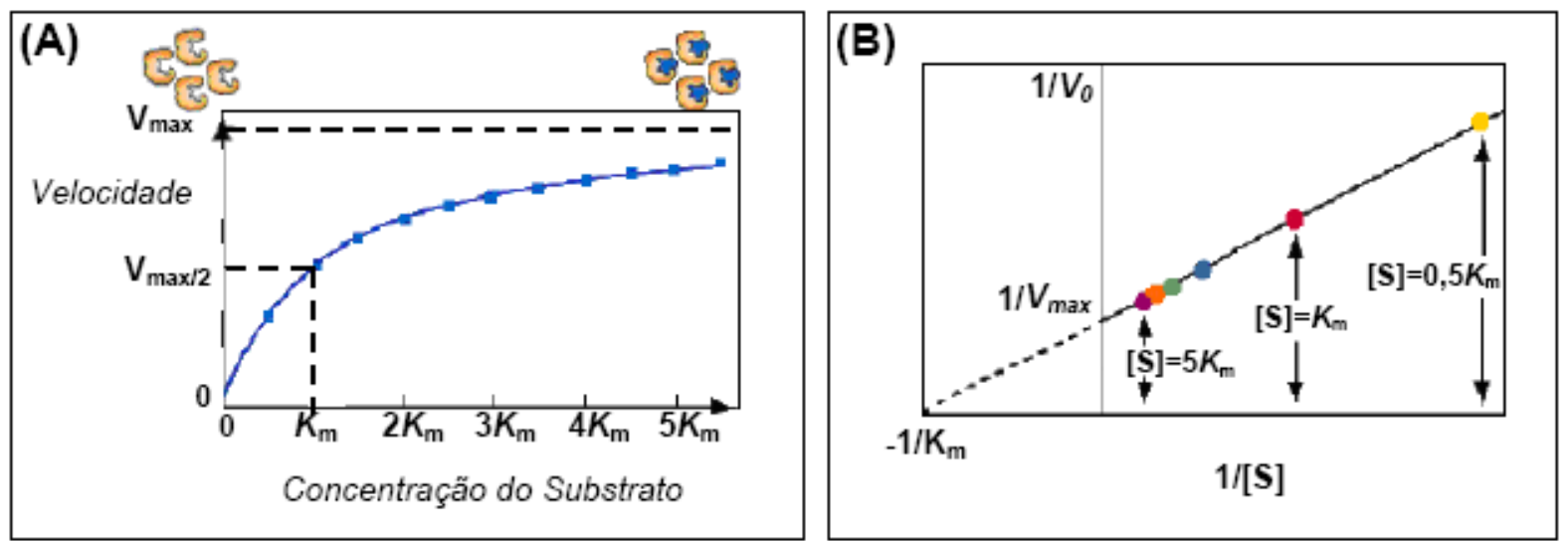

Figura 2. Efeito da concentração de substrato sobre a velocidade inicial da reação catalisada por enzimas. (A) Gráfico da velocidade inicial da reação versus concentração de substrato. (B) Relação de Lineweaver-Burk

As enzimas também têm as atividades alteradas em função do $\mathrm{pH}$, temperatura, força iônica e polaridade do meio, apresentando atividade máxima quando esses parâmetros são ótimos, o que depende da origem do organismo que sintetiza determinada proteína. A atividade de cada enzima na célula está sujeita a muitos mecanismos de regulação. A indução ou inibição 
da produção enzimática vai depender do desempenho das atividades celulares, estimulando ou inibindo a expressão dos genes envolvidos na biossíntese dessas macromoléculas.

Existe uma estreita relação entre estrutura e a função catalítica, uma vez que a estrutura protéica determina as interações entre a enzima e o substrato envolvidos na catálise. O substrato deve ser capaz de se ligar especificamente à enzima a fim de possibilitar sua transformação em produto. Assim, a estrutura do catalisador deve fornecer um conjunto de interações que permitam a ligação do substrato, expondo grupos químicos capazes de interagir entre si formando, transitoriamente, o complexo enzima-substrato. [4]

O substrato liga-se à enzima através do sítio ativo, região que contém resíduos de aminoácidos capazes de interagir com o substrato. É nesse sítio, também, que estão os resíduos de aminoácidos (grupos catalíticos) que diretamente participam da ruptura e do estabelecimento de ligações químicas que resultam na formação do produto. [4]

O sítio ativo da enzima é uma fenda (sulco) tridimensional localizada na sua superfície, formado por grupos provenientes de porções distintas da seqüência polipeptídica. São geralmente resíduos distanciados entre si na seqüência primária da molécula enzimática que adotam um arranjo conformacional que os aproxima como resultado de interações nãocovalentes, propiciando um ambiente favorável à ligação do substrato. [3]

Apesar do sítio ativo ser apenas uma pequena porção da enzima, a participação de outros aminoácidos na catálise enzimática nem por isso deve ser desprezada. Na verdade, em algumas enzimas, os aminoácidos restantes constituem-se em sítios regulatórios, de interação com outras moléculas (protéicas ou não) ou canais de aproximação dos substratos ao sítio ativo da enzima. A integridade da molécula enzimática é por isso necessária à atividade catalítica. [3] 
Em 1894, Emil Fischer propôs o modelo chave - fechadura para explicar a ação enzimática. A enzima (E) se encaixa ao substrato específico (S) no sítio ativo, como uma chave e fechadura: [5]

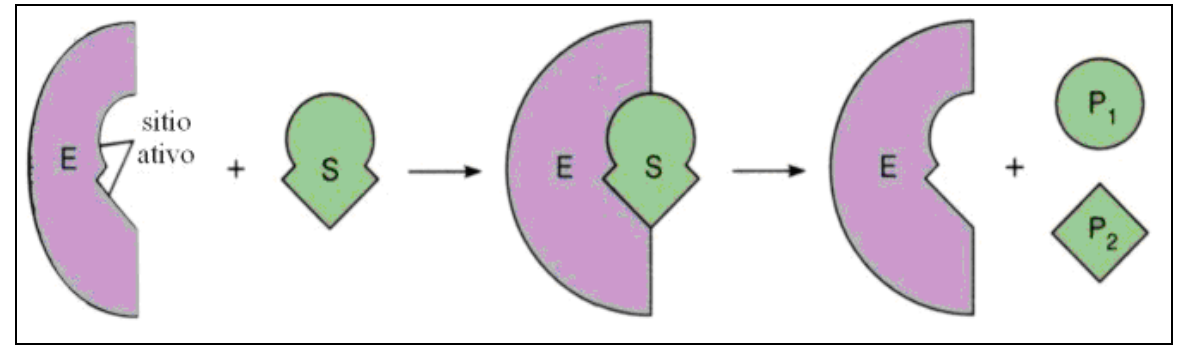

Figura 3. Modelo chave fechadura proposto por Fischer [6]

Em 1958, Koshland propôs o modelo denominado encaixe por indução, no qual tanto a enzima quanto o substrato sofrem conformação para o encaixe. A enzima não aceita simplesmente o substrato; o substrato é distorcido para conformação exata do estado de transição. Ao completar a reação catalítica a enzima libera o produto e retorna a forma original. O processo ocorre em duas etapas: [5]
(1) $\mathrm{S}+\mathrm{E}$
ES* (etapa reversível)
(2) $\mathrm{ES} \longrightarrow \mathrm{E}+\mathrm{P}$ (etapa irreversível)

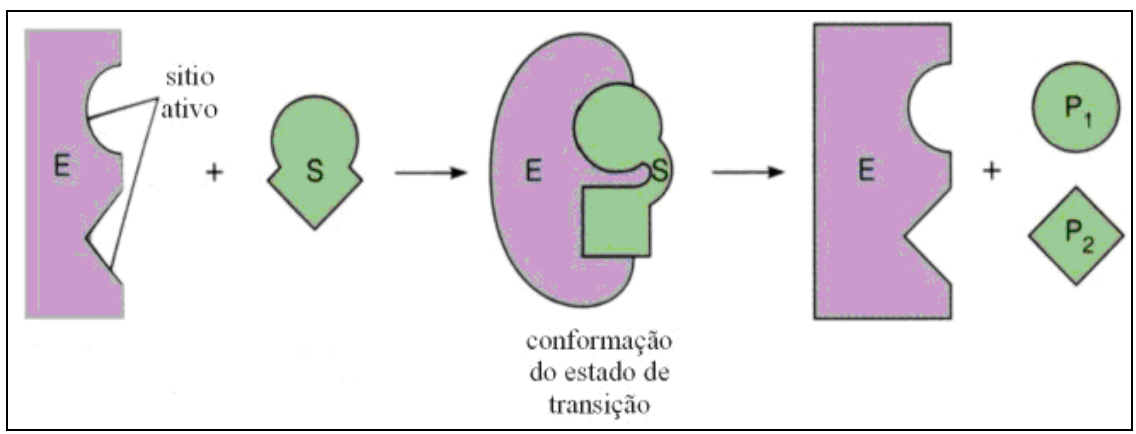

Figura 4. Modelo do ajuste induzido de Koshland [6] 
A União Internacional de Bioquímica e Biologia Molecular (UIBBM) classifica as enzimas em seis grupos e cada uma delas em subgrupos de acordo com o tipo de reações que catalisam. (Tabela 1): [4,5]

Tabela 1. Classificação das enzimas segundo a UIBBM: [4,5]

\begin{tabular}{cccc}
\hline Número & Classes & Tipo de reação catalisada & Subclasse \\
\hline 1 & Oxidorredutases & Transferência de elétrons ou remoção de hidrogênio & $\begin{array}{l}\text { Hidrogenases, oxidades, } \\
\text { peroxidades, redutases }\end{array}$ \\
\hline 2 & Transferases & Reações de transferência de grupos & Transaldolases, transcetolases \\
\hline 3 & Hidrolases & Reações de hidrólise & Esterases, lipases, peptidades, \\
& & fosfatases \\
\hline 4 & Liases & Reações de adição de grupos à ligação dupla ou & Descarboxilases, fosfatases \\
& & formação de ligações duplas por remoção de grupos & \\
\hline 5 & Ligases & Formação e clivagem de ligações C-C, C-S, C-O, C- & Sintetases \\
\hline & & N e ésteres de fosfato & Racemases, epimerases \\
\hline
\end{tabular}

As reações biocatalisadas apresentam vantagens em relação a muitas reações da química orgânica convencional: [2]

- as reações catalisadas por enzimas são realizadas em condições brandas, com temperatura abaixo de $100{ }^{\circ} \mathrm{C}$, sob pressão atmosférica e em um meio de $\mathrm{pH}$ e concentração salina praticamente constantes. Essas condições minimizam problemas de isomerização, racemização e rearranjos, que freqüentemente ocorrem na metodologia tradicional, além de 
apresentarem um excelente balanço energia-eficiência quando comparadas com processos químicos;

- enzimas podem promover reações que dificilmente podem ser simuladas pelas técnicas da síntese orgânica convencional, com velocidades cerca de $10^{6}$ a $10^{14}$ vezes maiores que nas reações não catalisadas;

- enzimas são catalisadores naturais que trazem benefícios comerciais e/ou ambientais;

- normalmente, utiliza-se água como meio reacional, embora isso dificulte uma série de reações orgânicas pela baixa solubilidade dos seus reagentes em água;

- as enzimas apresentam alta quimiosseletividade, regiosseletividade e estereosseletividade, além de possibilitar a geração de produtos com atividade ótica.

- Quimiosseletividade:

Algumas enzimas podem reagir com um único grupo funcional, mesmo na presença de outros grupos químicos reativos.

- Regiosseletividade:

Devido à sua estrutura tridimensional complexa, as enzimas podem distinguir entre grupos funcionais que estão situados em diferentes regiões da mesma molécula de substrato.

- Enantiosseletividade:

Como todas as enzimas são formadas por L-aminoácidos, são catalisadores quirais. Como conseqüência, qualquer tipo de quiralidade presente na molécula do substrato é "reconhecida" na formação do complexo enzima-substrato. Assim, por exemplo, apenas um dos enantiômeros de uma mistura racêmica pode ser convertido no produto desejado.

Contudo, o uso de biocatalisadores apresenta algumas desvantagens tais como: i) dificuldade em sínteses de larga escala, ii) procedimentos de trabalho complicados no caso do uso 
de microrganismos, iii) podem ser necessários grandes espaços para o cultivo das células, iv) longos tempos de reação, v) requerem parâmetros de operação específicos, tais como temperatura e pH e vi) são propensos a sofrer inibição por agentes químicos e físicos. Essas desvantagens têm sido amenizadas nos últimos anos pelo desenvolvimento e aperfeiçoamento de diversas técnicas. Os avanços da bioquímica, química de proteínas, biologia celular e molecular, além da tecnologia de fermentações, têm disponibilizado um número ilimitado de enzimas e culturas microbianas como ferramentas valiosas na transformação de diferentes compostos de interesse. [7]

Os sistemas em biocatálise podem utilizar células íntegras de organismos vivos ou enzimas. As células íntegras têm como vantagens o baixo custo e o fato de conter tanto as enzimas quanto suas coenzimas necessárias. Contudo, por serem um sistema multienzimático, podem ocorrer reações laterais, além de problemas de permeabilidade do substrato pela membrana. Por outro lado, enzimas isoladas oferecem maior controle do processo, boa produtividade e tolerância a altas concentrações de substrato, apesar do custo mais alto pela tecnologia aplicada na sua purificação, com a menor perda de atividade possível. [8]

\section{3- Aplicações industriais das enzimas}

As enzimas encontradas na natureza têm sido utilizadas desde a Antigüidade na produção de alimentos como o queijo, a cerveja, o vinho e o vinagre, e na manufaturação de mercadorias como o couro e o linho. Todos esses processos eram realizados pelo crescimento espontâneo de microrganismos ou pela adição de enzimas presentes em algumas preparações; não havia o uso de enzimas em sua forma pura e bem caracterizada. [9]

O uso de enzimas na indústria, como é conhecido hoje, é resultado de um rápido desenvolvimento, nas quatro últimas décadas, da biotecnologia moderna que revolucionou o 
conhecimento sobre as enzimas, com a sua purificação e possível comercialização favorecendo a produção em escala industrial. [10] Hoje, é bastante diversificado e amplo o campo de aplicação industrial das enzimas, abrangendo áreas tão diversas como a indústria alimentícia, têxtil e de detergentes, como mostrado na Tabela 2. [9]

Tabela 2: Enzimas utilizadas em diferentes segmentos industriais:

\begin{tabular}{|c|c|c|}
\hline Segmento Industrial & Enzima & Aplicações \\
\hline Detergentes & protease, lipase, amilase, celulase & remoção de manchas \\
\hline Álcoois combustíveis & $\begin{array}{l}\text { amilase, amidoglucosidase, glucose } \\
\text { isomerase }\end{array}$ & $\begin{array}{l}\text { liqüefação do amido, sacarificação e } \\
\text { conversão da glicose a frutose }\end{array}$ \\
\hline Alimentos & $\begin{array}{l}\text { protease, amilase, lactase, } \\
\text { transglutaminase, lipoxigenase }\end{array}$ & $\begin{array}{l}\text { coagulação do leite, queijo, remoção da } \\
\text { lactose, branqueamento e amaciamento do } \\
\text { pão }\end{array}$ \\
\hline Bebidas & $\begin{array}{l}\text { amilase, } \beta \text {-glucanase, acetolacto } \\
\text { descarboxilase, lacase }\end{array}$ & tratamento de sucos, mosturação de cervejas \\
\hline Têxteis & celulase, amilase, catalase & $\begin{array}{l}\text { amaciamento das fibras do algodão, } \\
\text { remoção do excesso de tintas }\end{array}$ \\
\hline Cosméticos & $\begin{array}{l}\text { amiloglicosidase, glicose oxidase, } \\
\text { peroxidase }\end{array}$ & atividade antimicrobiana \\
\hline
\end{tabular}

A indústria farmacêutica apresenta interesse particular no uso de enzimas em sínteses assimétricas. Isômeros óticos de fármacos podem apresentar atividades biológicas diferentes e, algumas vezes, incompatíveis, podendo um deles ser tóxico, o que torna impossível o uso terapêutico da mistura racêmica. Através da biocatálise é possível a síntese preferencial de um 
dos enantiômeros com alto grau de pureza, já que é recomendável um excesso enantiomérico mínimo de 98\% para possível comercialização do fármaco. [11]

Um dos casos mais conhecidos é o da talidomida (Figura 5), droga usada nos anos 60, como mistura racêmica, para aliviar sintomas de enxaqueca e náuseas em gestantes. No entanto, quando mulheres grávidas fizeram uso do fármaco, os recém-nascidos revelaram deficiências graves. Descobriu-se depois que só um dos enantiômeros tem efeito analgésico, sendo o outro o responsável pelas deformações teratogênicas causadas em recém-nascidos. [12]

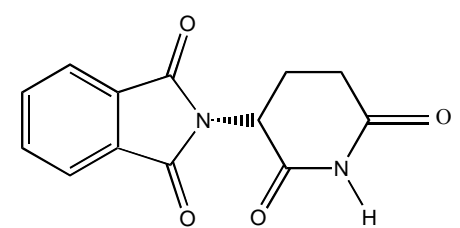

(R) - talidomida (sedativo)<smiles>O=C1CC[C@H](N2C(=O)c3ccccc3C2=O)C(=O)N1</smiles>

(S) - talidomida (teratogênico)

Figura 5. Enantiômeros da talidomida

\section{4- Resolução enzimática}

Quando um substrato racêmico é submetido a uma reação enzimática, este sofre discriminação quiral. Seus enantiômeros interagem com o reagente quiral, gerando dois estados de transição diastereoisoméricos com diferentes energias livre de Gibbs e, portanto, com diferentes constantes de velocidade, Figura 6. [13] O enantiômero que melhor se ajusta ao sítio ativo da enzima sofre reação em uma velocidade mais alta. Para assegurar uma alta seletividade para ambos os enantiômeros, a diferença nas suas velocidades de reação deve ser a maior possível. Em casos ideais, essa diferença é tão extrema que um enantiômero é transformado rapidamente enquanto o outro nem é convertido. Assim, a reação enzimática cessaria com $50 \%$ 
de conversão, quando já não existe mais o enantiômero reativo. Como conseqüência, cada enantiômero pode ser obtido somente com $50 \%$ de rendimento em uma resolução enzimática. [5]

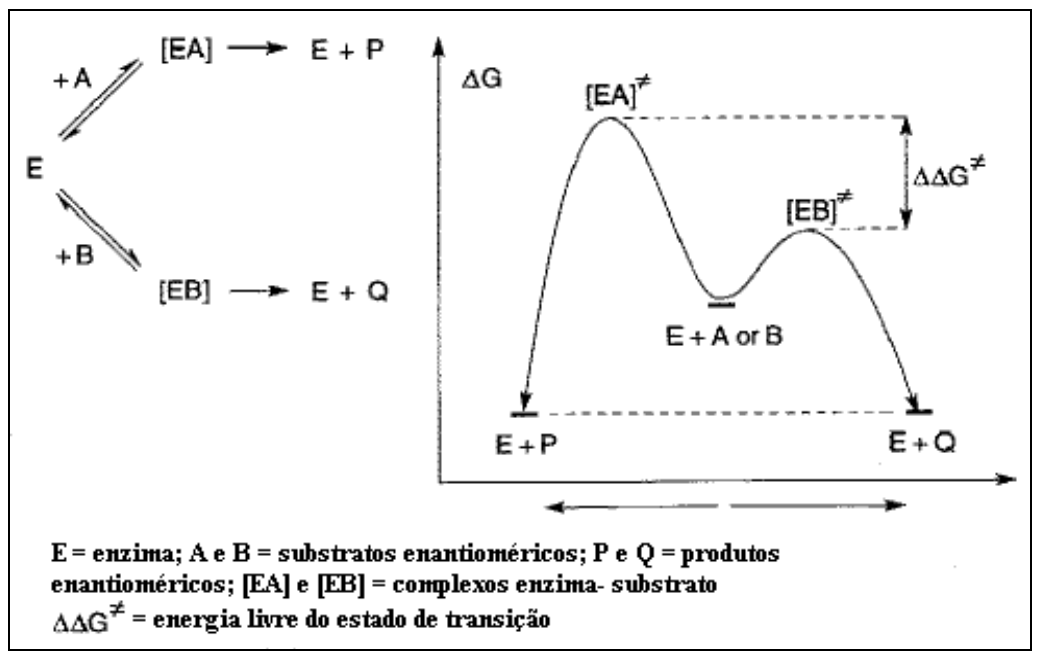

Figura 6. Diagrama de energia para uma reação enantiosseletiva catalisada por enzima

A eficiência da síntese assimétrica ou grau de seletividade na obtenção preferencial de um dos enantiômeros é avaliada em termos de excesso enantiomérico (e.e.) Equação 1. [15]

$$
\mathrm{ee}=\frac{(A-B)}{(A+B)} \times 100
$$

$A$ e $B=$ quantidades relativas dos enantiômeros

Um excesso enantiomérico de $100 \%$ corresponde a um composto enantiomericamente puro, sendo a reação que fornece essa pureza chamada de enantioespecífica. $O$ excesso enantiomérico de $0 \%$ corresponde a uma mistura (1:1) de enantiômeros, conhecida como mistura racêmica ou racemato, denotada pelo prefixo $( \pm)$. [5] 


\section{5- Métodos analíticos para a determinação da pureza enantiomérica}

A separação dos enantiômeros de uma mistura representa um desafio, uma vez que eles apresentam, em geral, propriedades físicas e químicas idênticas. Contudo, os enantiômeros apresentam desvios diferentes da luz polarizada no plano e diferem nas reações com outros compostos oticamente ativos. O desenvolvimento de métodos de análise estereoquímica sensível, especialmente dos cromatográficos de alta resolução para a determinação da pureza enantiomérica, foi fundamental para o desenvolvimento da síntese assimétrica, pois permite a avaliação precisa do grau de seletividade obtido em uma determinada reação. [16]

\subsubsection{Método polarimétrico}

O método clássico para determinar o excesso enantiomérico de uma amostra é medir sua pureza ótica através de um polarímetro (aparelho que mede o desvio, em graus, da luz polarizada no plano ao atravessar uma solução de uma substância oticamente ativa). Determinase assim o ângulo de rotação ótica experimental, sendo esse convertido para a rotação ótica específica $[\alpha]^{\mathrm{T}}$ D, grandeza característica de cada composto, calculada pela Equação 2. [16]

$$
[\alpha]^{T}{ }_{D}=\frac{\alpha}{\text { I.c }} \quad \text { Equação (2) onde: }
$$

\footnotetext{
$\alpha=$ rotação ótica observada

$1=$ comprimento da cela polarimétrica $(\mathrm{dm})$

$\mathrm{D}=$ comprimento de onda da linha de emissão de $\mathrm{Hg}(\lambda=589 \mathrm{~nm})$

$c=$ concentração da solução $\left(\mathrm{g} / \mathrm{cm}^{3}\right)$

$\mathrm{t}=$ temperatura $\left({ }^{\circ} \mathrm{C}\right)$
} 
A medida da rotação ótica de uma amostra deve ser realizada sob condições definidas de temperatura, solvente, concentração e em um dado comprimento de onda de incidência da luz polarizada no plano. A rotação da luz polarizada no plano é igual em magnitude para ambos enantiômeros, mas com sinal contrário. Na literatura encontram-se valores de $[\alpha]$ para vários compostos oticamente ativos. Esse dado não só é utilizado como critério de identificação de uma substância, mas também para avaliar a pureza ótica ou a sua porcentagem em uma mistura. Se a medida for realizada sob condições controladas rigorosamente e calibrações apropriadas, o valor pode ser comparado com o da "pureza enantiomérica". [16]

A porcentagem de pureza enantiomérica é freqüentemente chamada de excesso enantiomérico (ee). Deve-se sempre considerar que o termo pureza ótica é aplicado para um único enantiômero ou mistura de enantiômeros e não deverá ser aplicado para misturas na qual outro composto estiver presente. Pode-se, portanto, definir ee em termos da rotação específica:

\section{ee $=\frac{\text { rotação específica observada }}{\text { rotação específica do enantiômero puro }} \times 100 \quad$ Equação (3)}

Embora este método seja uma técnica geralmente usada para determinar a pureza enantiomérica, apresenta algumas desvantagens. A amostra analisada deve ser homogênea, destituída de traços de impurezas quirais e deve ser isolada de uma mistura reacional sem enriquecimento enantiomérico acidental. [17]

As medidas de rotação ótica são particularmente sensíveis à temperatura e concentração. Dessa forma, os erros nas medidas de rotação desses efeitos combinados são estimados em $\pm 4 \%$. [17] 


\subsubsection{Cromatografia gasosa quiral (CGQ)}

Um método útil para a análise de misturas enantioméricas é o uso da cromatografia gasosa (CG) com fase estacionária quiral (CGQ). Esse método além de sensível não é afetado por traços de impurezas, é rápido e relativamente simples de ser realizado. Está baseado em associações moleculares que podem levar a um reconhecimento quiral suficiente que resulte em uma resolução enantiomérica. A razão dos picos fornece uma medida da composição enantiomérica da amostra precisa e quantitativa. Tais medidas podem ser realizadas com um alto grau de precisão $( \pm 0,05 \%)$. [18]

O método usa uma fase estacionária quiral que contém um agente de resolução auxiliar de alta pureza enantiomérica. Os enantiômeros sofrem interações diastereoisoméricas rápidas e reversíveis com a fase estacionária, sendo eluídos em velocidades diferentes. A amostra deve ser suficientemente volátil e estável termicamente, e ser resolvida quantitativamente sobre a fase quiral. A resolução dos enantiômeros pela cromatografia baseia-se na diferença entre energias livres de formação dos intermediários diastereoisoméricos transitórios formados durante a eluição. [18]

As ciclodextrinas têm sido aplicadas com sucesso na separação de enantiômeros pela cromatografia líquida ou gasosa, através do desenvolvimento de colunas com fases estacionárias quirais. As ciclodextrinas são oligossacarídeos cíclicos contendo 6, 7 ou 8 unidades de glicose, sendo denominadas de $\alpha-, \beta-$ e $\gamma$-ciclodextrina, respectivamente. As unidades de glicose, unidas por ligações $\alpha(1 \rightarrow 4)$, estão espacialmente arranjadas na forma de um cone cortado. A cavidade da ciclodextrina é relativamente apolar e sua superfície polar, devido aos grupos hidroxila que podem sofrer reações químicas, formando derivados. O mecanismo de separação está baseado na formação de complexos de inclusão entre o soluto quiral e a ciclodextrina, devido à inclusão da 
parte hidrofóbica da molécula quiral na cavidade hidrofóbica da ciclodextrina e interação dos grupos hidrofílicos com as hidroxilas ou com os grupos resultantes da sua derivação. [19]

Existem certamente limitações para o método, algumas das quais são peculiares para a cromatografia gasosa. As amostras deverão ser suficientemente voláteis, termicamente estáveis e, é claro, quantitativamente resolvidas pela coluna quiral utilizada. [18]

\subsubsection{Cromatografia líquida de alta eficiência - CLAE}

A separação dos enantiômeros por CLAE, como na CG, requer um agente quiral. O método mais direto é o de induzir interações diastereoisoméricas dos dois enantiômeros com a fase quiral estacionária. Os complexos diastereoisoméricos formados terão estabilidades diferentes e, portanto, eluirão em tempos diferentes. A resolução direta de enantiômeros é possível desde que exista reconhecimento quiral entre a mistura racêmica e o seletor quiral.

Não existe uma fase estacionária quiral universal capaz de solucionar todos os problemas de separação, mas sim diversas fases com diferentes princípios de separação. As mais utilizadas são as fases estacionárias protéicas e as de polímeros helicoidais. Em muitos casos, a única maneira de realizar a resolução do par de enantiômeros é através da seleção de uma coluna apropriada, variando a porcentagem ou o tipo de modificador orgânico para controlar a retenção dos enantiômeros. [20,21] 


\section{6- Epóxidos}

Os epóxidos são éteres cíclicos com anéis de três membros, de grande interesse para os químicos orgânicos, uma vez que são elementos estruturais comuns de diversas macromoléculas biologicamente ativas e também por sofrerem facilmente reações de abertura de anel estereosseletivas e regiosseletivas com uma vasta gama de nucleófilos. Assim, são reagentes de partida e intermediários versáteis para a síntese de compostos que apresentam atividades biológicas interessantes, sendo vantajoso, portanto, que os epóxidos estejam estereoquimicamente puros quando usados, por exemplo, como substrato em sínteses assimétricas. [22,23]

Na Figura 7 estão representados alguns epóxidos biologicamente importantes: [22]

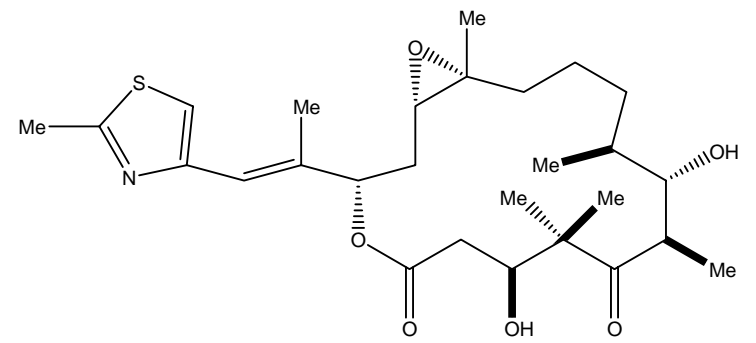

Epotilona A

Agente anti-tumoral<smiles>CCC(=CCCC(C)=CC(C)=O)CC[C@@H]1O[C@@]1(C)C[Na]</smiles>

Hormônio de insetos jovens (JH I)

Regulador do crescimento de insetos

\section{Óxido de etileno}

Desinfetante e fungicida

Figura 7. Exemplos de epóxidos biologicamente importantes

A Figura 8 apresenta um esquema mostrando a abertura de epóxidos, favorecida pela grande reatividade da função oxirano, oriunda da tensão do anel de três membros e da forte polarização da ligação C-O, frente a vários nucleófilos. [24] 

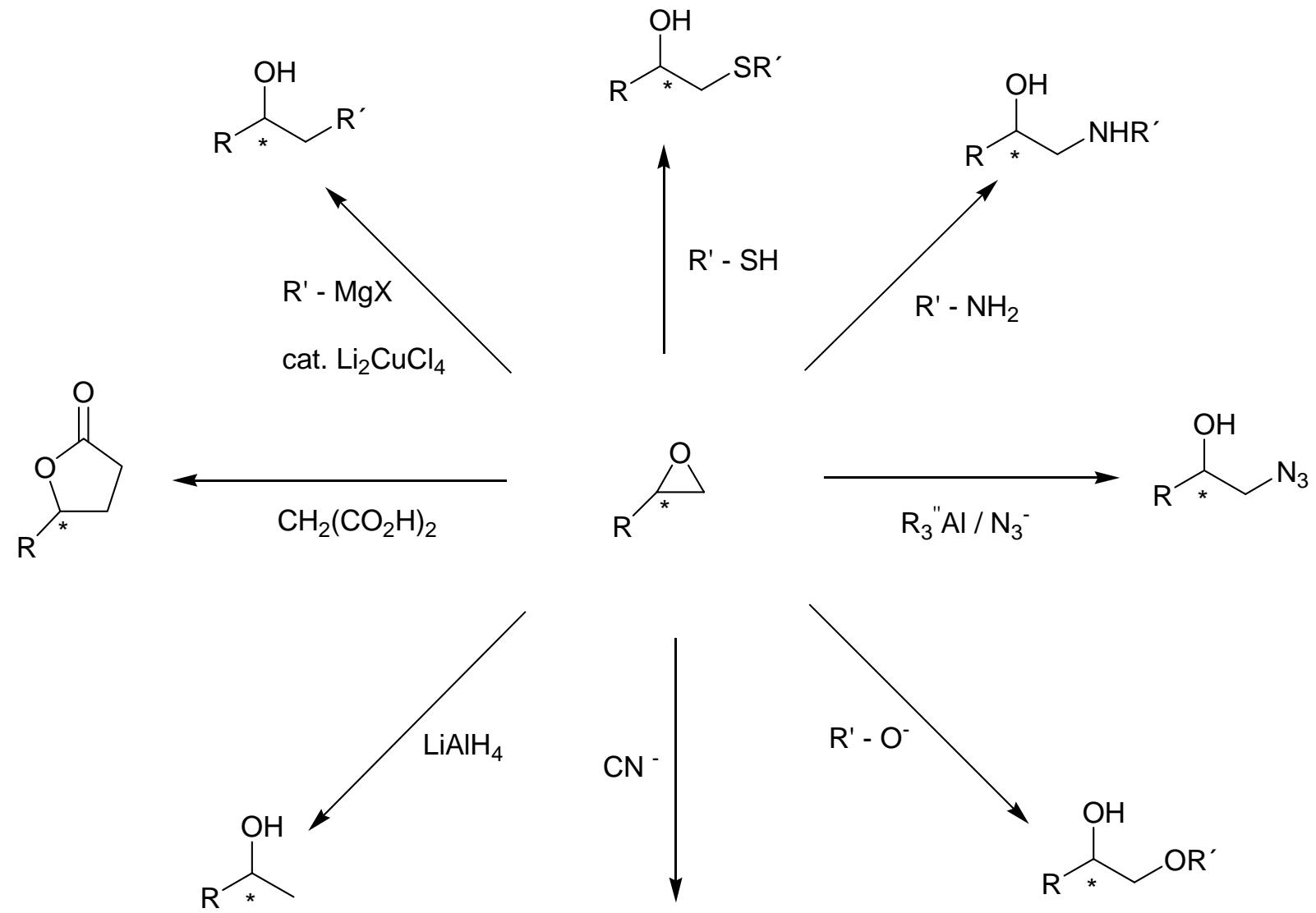<smiles>[R]C(O)CC#N</smiles>

Figura 8. Produtos da abertura de epóxidos com diferentes nucleófilos

Epóxidos são instáveis em condições ácidas ou básicas. Assim, é importante selecionar uma condição apropriada para minimizar sua hidrólise química durante o processo de biotransformação. A abertura do anel epóxido em meio ácido ou básico leva a uma mistura racêmica de dióis, como representado na Figura 9. 


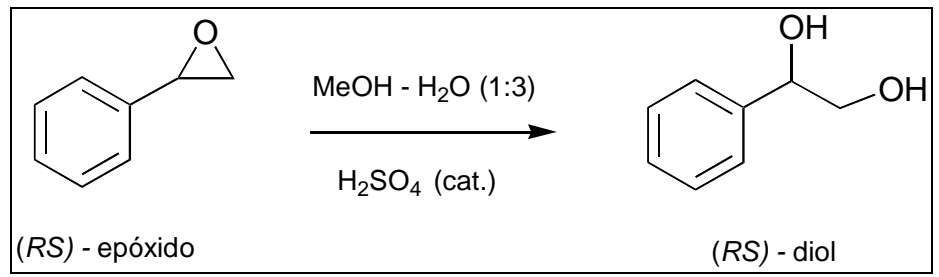

Figura 9: Abertura do epóxido estireno em meio ácido.

As diferentes metodologias para a síntese preferencial de um dos enantiômeros do diol usam tanto catalisadores químicos (baseados em metais de transição) quanto catalisadores biológicos - cada uma apresentando suas vantagens e desvantagens. Uma das estratégias mais promissoras é a resolução enzimática da hidrólise dos epóxidos racêmicos com a utilização de enzimas conhecidas como epóxido hidrolases (EHs). [22]

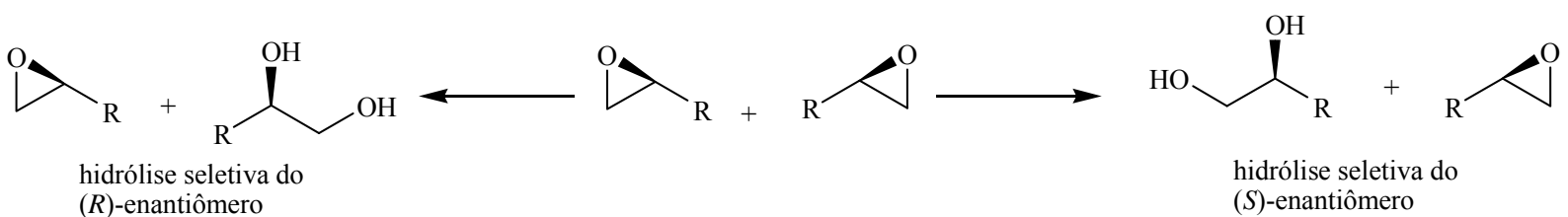

Figura 10. Esquema da resolução enzimática de um alquil-epóxido [22]

\section{7- Epóxido hidrolases}

As epóxido hidrolases (EHs) catalisam a adição de uma molécula de água ao anel oxirano para formar o correspondente diol. Sua importância é justificada, primeiramente, por serem enzimas independentes de cofatores, fáceis de usar e estáveis, tendo, portanto, um grande potencial em aplicações industriais.

As EHs são onipresentes na natureza, podendo ser encontradas em bactérias, leveduras, fungos, plantas, insetos e até nos mamíferos. Apesar de algumas epóxido hidrolases apresentarem funções regulatórias bem específicas (como a enzima responsável pela hidrólise do hormônio de insetos jovens I), a maioria das EHs é responsável pela desintoxicação xenobiótica, 
diminuindo a toxicidade de reações que utilizam epóxidos como intermediários, convertendo-os em metabólitos mais polares e hidrossolúveis (dióis), sendo assim mais fáceis de serem eliminados. [22]

Por apresentarem diversas fontes microbianas possíveis e estarem disponíveis em grandes quantidades, EHs microbianas têm sido amplamente exploradas em sínteses orgânicas e no uso em larga escala (depois de sua clonagem e expressão em hospedeiro apropriado). Em muitos casos, elas se apresentam em altos níveis mesmo quando os microrganismos crescem em condições não otimizadas, e dependendo do substrato apresentam altas enantiosseletividade e atividade. [25]

No entanto, pouquíssimas EHs foram relatadas de microrganismos marinhos. Assim, é de enorme interesse isolar-se novas EHs, com novas características quanto a enantiosseletividade e/ou regiosseletividade, vindas de microrganismos marinhos, para expandir o uso potencial das EHs na biocatálise industrial. [25]

Um mecanismo geral para a hidrólise enzimática de epóxidos é mostrado na Figura 10. A maioria dos estudos sobre o mecanismo das epóxido hidrolases tem sido realizada com enzimas de mamíferos, mas devido às similaridades qualitativas existentes entre as epóxido hidrolases de diferentes espécies, acredita-se que todas funcionam de maneira similar. [22]

A família das epóxido hidrolases apresenta uma tríade catalítica formada por um nucleófilo (como os aminoácidos Ser, Cys ou Asp) que participa da formação de um intermediário acil ou aril com a enzima, por uma base (geralmente His) e por um ácido (Tyr, Asp ou Glu) que promove a hidrólise do intermediário. [26]

Inicialmente, o epóxido sofre o ataque nucleofílico do íon carboxilato do resíduo do aminoácido aspartato, levando à formação do intermediário acil glicol. Numa segunda etapa, o intermediário acil glicol é hidrolisado pelo ataque do $\mathrm{OH}^{-}$da água, formado pela perda de um 
próton da molécula de água para a base histidina, e libera então o diol como produto, recuperando o íon aspartato e a enzima, Figura 11. [27]

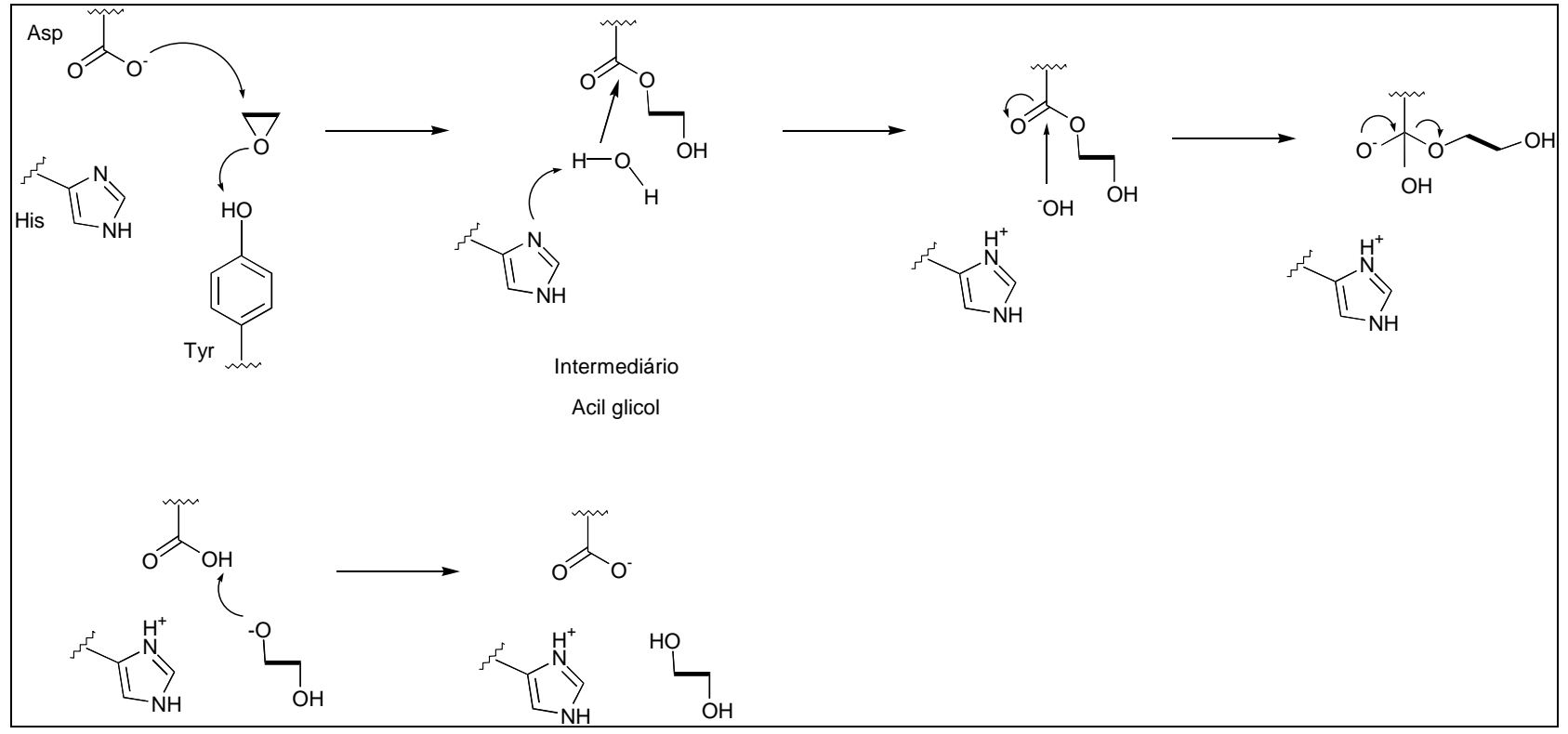

Figura 11. Mecanismo da hidrólise enzimática do epóxido [5]

O mecanismo anteriormente proposto implica em importantes conseqüências estereoquímicas na resolução enzimática de epóxidos não simetricamente substituídos. Como o mecanismo envolve o ataque nucleofílico de uma hidroxila em um átomo de carbono do oxirano, sua configuração absoluta pode ser mantida ou invertida, dependendo do padrão de substituição do átomo de carbono que sofreu o ataque e da regiosseletividade da enzima. [27] A hidrólise enzimática pode ocorrer através de dois caminhos, Figura 12:

- Ataque no carbono menos substituído do epóxido, resultando na retenção da configuração;

- Ataque no centro estereogênico, resultando na inversão da configuração. 


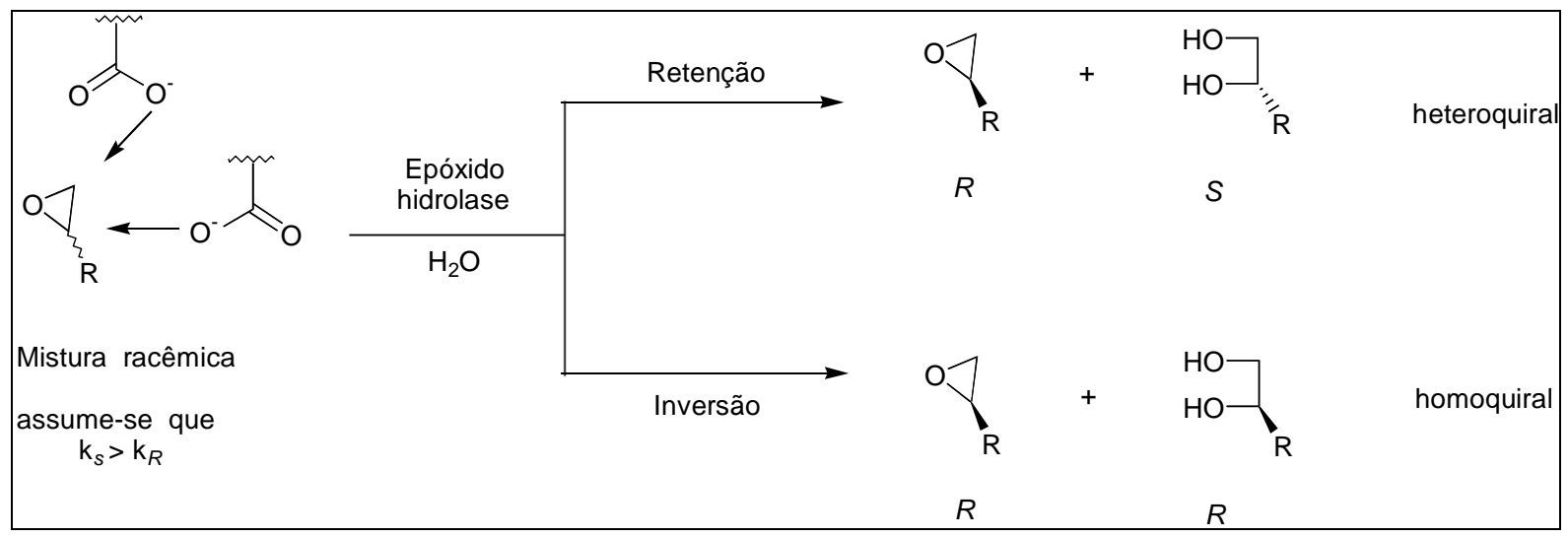

Figura 12. Hidrólise enzimática de epóxidos com retenção e inversão de configuração

Embora a retenção de configuração pareça o caminho mais comum, é necessário que se conheça a configuração dos substratos e dos produtos, provenientes da resolução enzimática, para que se possa determinar o caminho estereoquímico preferencial realizado por diferentes epóxido hidrolases. [5]

\section{8- Revisão bibliográfica para EHs}

As enzimas foram usadas por milhares de anos na forma de preparações brutas de origem animal, vegetal ou microbiana, sem que suas estruturas e propriedades fossem conhecidas. Os egípcios já utilizavam enzimas presentes em microrganismos no processo de fermentação do suco de uva para obtenção de vinho, fabricação de queijo e pão. [13]

Van Helmont, no século XVII, considerava a transformação dos alimentos um processo químico mediado por "fermentos". A experiência de Spallanzani (1729-1799) demonstrou que o suco gástrico continha um "princípio" capaz de liquefazer a carne. [28]

Em 1814, Kirchoff demonstrou a conversão do amido em açúcar por um extrato de trigo. Quase vinte anos depois (1833), outro marco no conhecimento da enzimologia foi a 
demonstração da conversão do malte em extrato etanólico por Payen e Persoz. Eles nomearam de diastase o fenômeno da conversão de amido em açúcar. Atividade semelhante foi observada, posteriormente, na saliva. [28]

Pasteur, em 1860, demonstrou através de uma série de experimentos que a fermentação alcoólica só ocorria em presença de células vivas de levedura. Na mesma época, Liebig defendia que os processos fermentativos eram reações químicas. Daí originou-se a denominação ENZIMA, que vem do grego e significa "na levedura", proposta por Kuhne em 1878, o qual acreditava que catalisadores desse tipo só atuavam dentro das células vivas. [28]

A polêmica Pasteur-Liebig foi resolvida, em 1897, pelo trabalho dos irmãos Büchner, que maceraram a levedura para obter um extrato inteiramente livre de células, o qual era capaz de fermentar o açúcar do mesmo modo que as células de levedura. Isso significava que o extrato continha os catalisadores da fermentação alcoólica, o que tornava possível estudar "in vitro" as reações químicas da fermentação. A partir daí o progresso no conhecimento no modo de ação dos catalisadores foi rápido, pois as reações catalisadas poderiam ser estudadas isoladamente e sob condições controladas. [28]

No entanto, a natureza química das enzimas ainda não era conhecida e isso só se tornou possível mais tarde, após um número de enzimas terem sido cristalizadas e caracterizadas como sendo proteínas. A primeira enzima a ser cristalizada (em 1926 por Summer) foi a urease, isolada do feijão. [28]

O desenvolvimento da ultracentrifugação por Svedberg (por volta de 1920) permitiu a criação de centrífugas capazes de sedimentar macromoléculas. Esses estudos mostraram que proteínas em solução geralmente consistiam de moléculas homogêneas, com massa molecular variando entre $10^{4}$ e $10^{7} \mathrm{Da}$. Assim, a descrição da estrutura enzimática em termos químicos tornou-se uma possibilidade real. Isso foi realizado em 1960, quando a seqüência de aminoácidos 
da ribonuclease (enzima que catalisa a hidrólise do ácido ribonucléico) foi deduzida. Em 1965, a estrutura tridimensional da lisosima (enzima que cliva a parede celular de certas bactérias) foi determinada por uma técnica de cristalografia e o primeiro mecanismo de ação pôde ser postulado em termos estruturais. A evolução no estudo das enzimas, acompanhada por avanços tecnológicos, possibilitou o isolamento e a identificação de suas propriedades. [28]

O primeiro relato do uso da enzima epóxido hidrolase é de 1972, por Suzuki e Marumo, utilizando o microrganismo Heminthosporum sativum na hidrólise do 10,11epoxifarnesol, levando ao (S)-diol correspondente com excesso enantiomérico de 73\%. [29]

A primeira hidrólise de epóxidos em escala preparativa foi relatada por Furstoss, com o uso do fungo Aspergillus niger na conversão enantiosseletiva do geraniol- $N$-fenilcarbamato no seu (S)-epóxido com alta pureza ótica [30]; esse, mais adiante, foi convertido no composto de Bower, um análogo do hormônio de insetos jovens. Furstoss utilizou inicialmente o micélio do fungo, passando a utilizar a enzima liofilizada. Alguns substratos hidrolisados com alta enantiosseletividade por Aspergillus niger são mostrados na Figura 13.
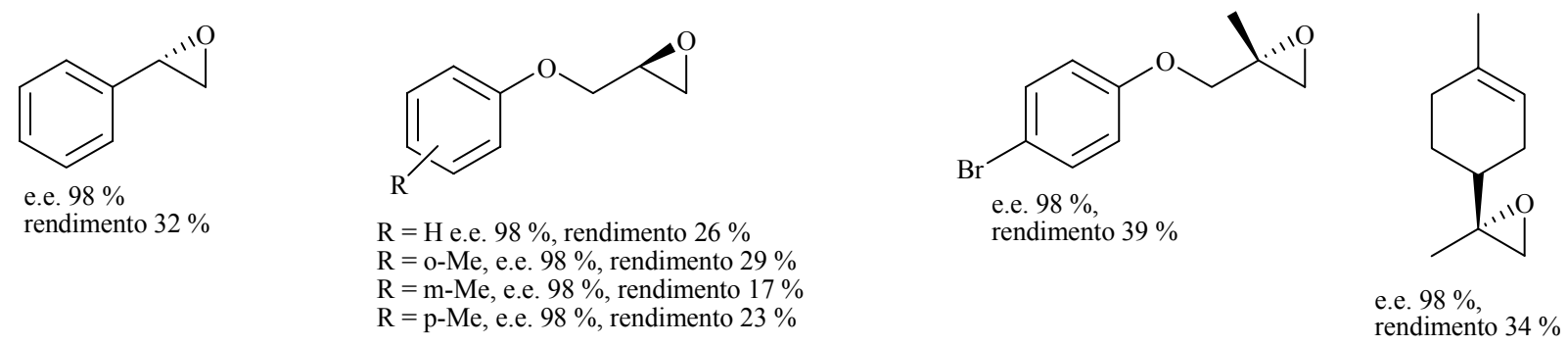

Figura 13. Resolução de epóxidos usando EHs de Aspergillus niger

Mais recentemente, Monfort descreveu com alto rendimento a síntese de um composto antifúngico utilizando uma versão recombinante de EH de Aspergillus niger (expressada em E.coli). [31] A atividade enzimática da epóxido hidrolase foi também detectada 
em Beauveria sulfurescens ATCC 7159, que converteu o óxido de estireno e outros epóxidos ligados a anéis de dois membros, com altas enantiosseletividades, Figura 14. [32]

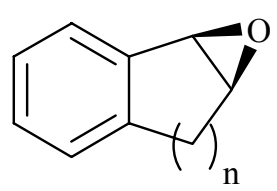

$\mathrm{n}=0$, e.e. $98 \%$, rendimento $20 \%$ $\mathrm{n}=1$, e.e. $98 \%$, renidmento $38 \%$<smiles>c1ccc([C@@H]2CO2)cc1</smiles>

e.e. $98 \%$ rendimento $34 \%$

Figura 14. Resolução de epóxidos usando EH de Beauveria sp

Na busca por uma EH enantiosseletiva capaz de resolver o óxido de indeno, precursor para um fármaco contra o vírus HIV, pesquisadores da Merck encontraram em cerca de 80 fungos investigados, que Diploida gossipina ATCC 116391 e Lasiodiploida theobromae MF5215 apresentavam excelentes enantiosseletividades conduzindo exclusivamente ao enantiômero desejado (1S, 2R), Figura 15. [33]

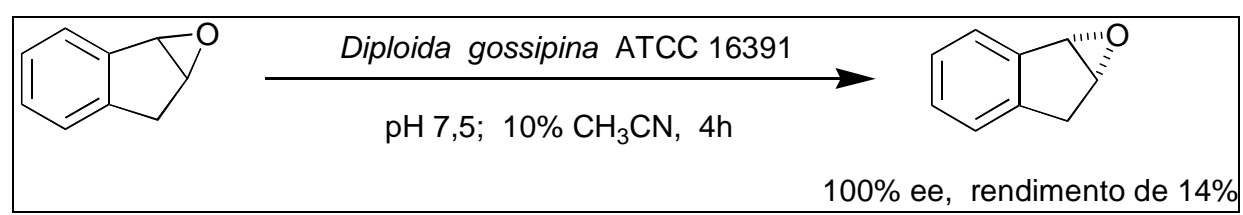

Figura 15: Resolução do óxido de indeno catalisada por EH de Diploida gossipina.

A importância desses biocatalisadores estimulou também o registro de patentes, como a preparação de dióis monoméricos ou poliméricos úteis como lubrificantes aditivos anticorrosivos ou agentes quelantes. Os dióis foram preparados a partir do tratamento dos epóxidos com as hidrolases isoladas das espécies Aspergillus. [34] 


\section{9- Haloidrinas}

Haloidrinas são intermediários sintéticos úteis e de amplas aplicações em química orgânica. Os reagentes convencionais para a abertura do anel oxirano convertendo-o em haloidrina são os haletos de hidrogênio. Contudo, essa conversão apresenta a desvantagem da intolerância à acidez do meio e a formação de subprodutos indesejáveis. Uma variedade de outros reagentes, como haletos de amônio na presença de sais metálicos e particularmente haletos de $\mathrm{P}$, $\mathrm{Al}, \mathrm{Fe}, \mathrm{Cu}$ e Li estão também disponíveis para essa transformação, apesar de apresentarem baixos rendimentos. Assim, existe um interesse contínuo no desenvolvimento de metodologias mais eficientes e de baixo impacto ambiental para a conversão de epóxidos em haloidrinas. [35]

A aplicação de epóxidos e haloidrinas como precursores de fármacos necessita que esses estejam disponíveis nas suas formas enantioméricas puras, com um excesso enantiomérico superior a 99\%. Para as haloidrinas, isso pode ser obtido através de sua resolução enzimática utilizando-se desalogenases ou mesmo lipases. [36]

\subsection{0- Lipases}

As lipases são certamente as enzimas de maior interesse prático devido aceitarem uma grande variedade de substratos, possuírem uma estabilidade relativamente alta, não necessitarem de cofatores dispendiosos e de poderem ser facilmente obtidas comercialmente e com produtividade elevada a partir de microrganismos, nomeadamente fungos e bactérias. [37]

As lipases são empregadas em reações de esterificação, interesterificação e hidrólise de ésteres, além de possuírem inúmeras aplicações industriais, onde se destacam as indústrias de detergentes, alimentícias, de papel, cosmética, farmacêutica, agroquímica, etc. [38] 
A lipase B de Candida antarctica (CALB) é, dentre várias enzimas, uma das mais utilizadas em biocatálise. Vários estudos têm demonstrado que essa enzima é particularmente útil na síntese de ésteres e aminas. A CALB mostra uma alta seletividade do substrato em relação à regiosseletividade e enantiosseletividade, sendo altamente regiosseletiva na síntese de monoésteres de hidratos de carbono e enantiosseletiva na resolução de inúmeros compostos como aminas, álcoois e ácidos. [39]

Sua estrutura foi determinada em 1994. Essa lipase é constituída por 317 aminoácidos, com um peso molecular de cerca de $30 \mathrm{kDa}$, Figura 16. Seu sítio ativo é constituído pela tríade catalítica Ser 105 - His 224 - Asp 187. Ao contrário da maioria das lipases, a CALB não apresenta ativação interfacial, sendo o acesso ao seu sítio ativo feito por um canal estreito, com a particularidade da existência de uma pequena hélice de elevada mobilidade perto desse sítio. [40]

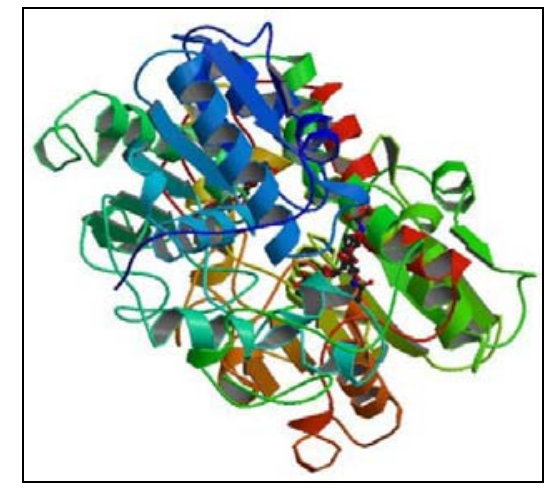

Figura 16. Estrutura tridimensional da lipase B de Candida antarctica (CALB).

A CALB encontra-se disponível no mercado, sob vários tipos de preparações, na forma livre ou imobilizada através de ligação iônica. Essa última apresenta uma elevada estabilidade durante longos períodos de tempo, na gama de temperaturas de $60-80{ }^{\circ} \mathrm{C}$. [41] 


\section{OBJETIVOS}

\section{Objetivo Geral}

Os objetivos deste trabalho foram realizar reações de biotransformação em epóxidos rcêmicos com microrganismos de origem marinha e sintetizar cloroidrinas.

\section{Etapas realizadas}

Neste trabalho atingiram-se as seguintes etapas:

- Sintetizaram os dióis racêmicos 1a-5a por métodos químicos para serem utilizados como padrões nas análises de cromatografia a gás com fase estacionária quiral de $\beta$-ciclodextrina.

- Realizou-se uma triagem com 4 fungos de origem marinha (Penicillium miczynskii Gc5, Trichoderma sp. Gc1, Aspergillus sydowii Gc12 e Penicillium raistrickii Ce16) nas reações de hidrólise epóxidos.

- Selecionou-se o fungo Trichoderma sp. Gc1 como sendo o melhor biocatalisador, pois as enzimas epóxido-hidrolases deste fungo catalisaram as reações de abertura de epóxidos.

- Otimizou as reações de biocatálise, determinando-se as melhores condições (o melhor biocalisador, a melhor quantidade de massa do biocatalisador, tempo de reação) a fim de se obter epóxidos e dióis enantiomericamente puros ou enriquecidos.

- Sintetizou as cloroidrinas $\mathbf{2 b} \mathbf{b} \mathbf{4 b}$ a partir da abertura dos epóxidos racêmicos 2-4 em solução de água do mar artificial ( $\left.1,5 \mathrm{~g} \mathrm{NaCl} / 10 \mathrm{~mL} \mathrm{H} \mathrm{H}_{2} \mathrm{O}\right)$.

- Realizou a resolução enzimática da cloridrina racêmica 4b com a lipase de Candida antarctica obtendo-se como produtos a cloroidrina $\mathbf{4 b}$ e seu respectivo acetato $\mathbf{4 c}$ com boa pureza enantiomérica. 


\section{PARTE EXPERIMENTAL}

\section{1 - Biotransformação de epóxidos racêmicos por microrganismos de origem marinha}

\subsection{1 - Síntese de dióis por método químico}

Em um balão de $125 \mathrm{~mL}$ contendo $10 \mathrm{~mL}$ de uma mistura de metanol:água $-1: 3$, adicionaram-se $200 \mathrm{mg}$ dos epóxidos comerciais (1 - 5) (Aldrich), Figura 17. A mistura foi levada para agitação à temperatura ambiente e posteriormente adicionou-se 1-2 gotas de ácido sulfúrico concentrado. A reação foi acompanhada por cromatografia em camada delgada, utilizando-se como eluente uma mistura de éter de petróleo: acetato de etila-1:1. Após 48 horas, observou-se que o material de partida foi consumido e em seguida neutralizou-se a reação com uma solução de KOH 1M. Após evaporação do metanol sob vácuo no rotaevaporador, extraiu-se a reação com acetato de etila. Os dióis 1a - 5a foram purificados por cromatografia em coluna utilizando-se como eluente uma mistura éter de petróleo: acetato de etila - 1:1.

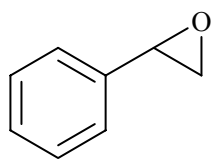

(RS)-1,2-epoxietilbenzeno (1)

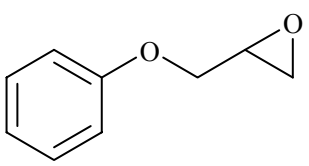

(RS)-2-(benziloximetil)oxirano (2)

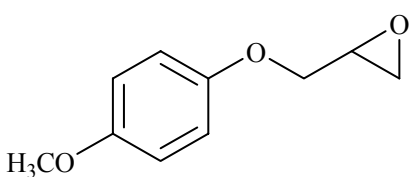

(RS)-2-[(4-metoxifenoxi)metil]oxirano (3)

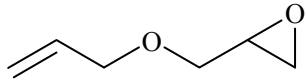

(RS)-2-(propeniloxi)oxirano (4)

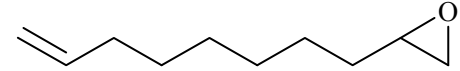

(RS)-1,2-epóxi-9-deceno (5)

Figura 17. Epóxidos racêmicos utilizados na síntese de dióis em meio ácido 
3.1.2 - Caracterização dos dióis racêmicos por métodos espectroscópicos (RMN ${ }^{1} \mathrm{H}, \mathrm{RMN}$ $\left.{ }^{13} \mathrm{C}, \mathrm{IV}\right)$

Os espectros obtidos para os dióis sintetizados a partir dos epóxidos racêmicos encontram-se na Seção A - Anexos. Os dióis 1a-5a apresentaram as seguintes caracterizações:

(RS)- 1-fenil-1,2-etanodiol (1a)<smiles>OCC(O)c1ccccc1</smiles>

$$
\begin{aligned}
& \text { Rendimento:79 \%. Sólido branco. p.f. }=39{ }^{\circ} \mathrm{C} \text {. } \\
& \text { RMN }{ }^{1} \mathrm{H}\left(\mathrm{CDCl}_{3}, 200 \mathrm{MHz}\right): \delta(\mathrm{ppm})=7,39- \\
& 7,26(\mathrm{~s}, 5 \mathrm{H}) ; 4,85-4,79(\mathrm{~m}, 1 \mathrm{H}) ; 3,75-
\end{aligned}
$$
$3,67(\mathrm{~m}, 2 \mathrm{H}) ; 3,71(\mathrm{sl}, 2 \mathrm{H}) . \mathrm{RMN}{ }^{13} \mathrm{C}\left(\mathrm{CDCl}_{3}, 50 \mathrm{MHz}\right): 140,53 ; 128,53(2 \mathrm{C}) ; 127,99 ; 126,05$ (2C); 74,66; 68,07. IV (pastilha KBr): $v\left(\mathrm{~cm}^{-1}\right)=3250,2930,2350,1460,1346,1237,1070,69$.

(RS)- 1,2-propanodiol- 3-fenilmetóxi (2a)<smiles>OCC(O)COCc1ccccc1</smiles>

Rendimento: $85 \%$. Líquido incolor. $\mathrm{RMN}{ }^{1} \mathrm{H}$ $\left(\mathrm{CDCl}_{3}, 200 \mathrm{MHz}\right): \delta=8,08-8,02(\mathrm{~m}, 1 \mathrm{H})$ $7,59-7,33 \quad(\mathrm{~m}, \quad 4 \mathrm{H}) ; 4,56 \quad(\mathrm{~s}, \quad 2 \mathrm{H})$

$3,77-3,55(\mathrm{~m}, 5 \mathrm{H}) ; 2,14(\mathrm{sl}, 2 \mathrm{H}) . \mathrm{RMN}{ }^{13} \mathrm{C}\left(\mathrm{CDCl}_{3}, 50 \mathrm{MHz}\right): 133,36 ; 128,47$ (2C); 127,94; 127,79 (2C); 73,62; 71,82; 70,60; 64,08. IV (filme líquido): $v\left(\mathrm{~cm}^{-1}\right)=3400,2900,2360,1720$, $1270,1090,710$. 
(RS)- 1,2-propanodiol- 3-(4-metoxifenóxi) (3a)<smiles>COc1ccc(OCC(O)CO)cc1</smiles>

Rendimento: $89 \%$. Sólido branco. p. $\mathrm{f}=119^{\circ} \mathrm{C}$ $\mathrm{RMN}{ }^{1} \mathrm{H}\left(\mathrm{CDCl}_{3}, 200 \mathrm{MHz}\right): \delta=6,85-6,84(\mathrm{~s}$, $4 \mathrm{H}) ; \quad 4,02-3,77 \quad(\mathrm{~m}, 3 \mathrm{H}) ; 3,77-3,76$ (m, 2H); 3,77 (s, 3H); 1,69 (sl, 2H). $\mathrm{RMN}^{13} \mathrm{C}\left(\mathrm{CDCl}_{3}, 50 \mathrm{MHz}\right): 154,27 ; 152,56 ; 115,57$ (2C); 114,73 (2C); 70,40; 70,05; 63,73; 55,74. IV (pastilha de KBr): $v\left(\mathrm{~cm}^{-1}\right)=3400,2900,2360,1500$, $1250,1030,810$.

(RS)- 1-alilóxi-2,3-propanodiol (4a)<smiles>C=CCOCC(O)CO</smiles>
Rendimento: $68 \%$. Líquido incolor. $\mathrm{RMN}{ }^{1} \mathrm{H}$ $\left(\mathrm{CDCl}_{3}, 200 \mathrm{MHz}\right): \delta=6,00-5,81(\mathrm{~m}, 1 \mathrm{H})$; $5,33-5,17 \quad(\mathrm{~m}, \quad 2 \mathrm{H}) ; \quad 4,05 \quad-\quad 3,39$ (m, 7H); 2,20 (sl, 2H). RMN ${ }^{13} \mathrm{C}\left(\mathrm{CDCl}_{3}, 50 \mathrm{MHz}\right): 134,22 ; 117,59 ; 72,48 ; 71,80 ; 70,58 ; 64,13$. IV (filme líquido): $v\left(\mathrm{~cm}^{-1}\right)=3390,2900,2350,1730,1650,1415,1070$.

(RS)- 9-deceno-1,2-diol (5a)<smiles>C=CCCCCCCC(O)CO</smiles>

Rendimento: $73 \%$. Líquido incolor. $\mathrm{RMN}{ }^{1} \mathrm{H}$ $\left(\mathrm{CDCl}_{3}, 200 \mathrm{MHz}\right): \delta=5,91-5,70(\mathrm{~m}, 1 \mathrm{H})$; $5,05-4,89 \quad(\mathrm{~m}, \quad 2 \mathrm{H}) ; \quad 3,67 \quad-3,60$ $(\mathrm{m}, 1 \mathrm{H}) ; 3,46-3,37(\mathrm{~m}, 1 \mathrm{H}) ; 2,41(\mathrm{~m}, 2 \mathrm{H}) ; 2,05-1,99(\mathrm{~m}, 2 \mathrm{H}) ; 1,41-1,12(\mathrm{~m}, 11 \mathrm{H}) . \mathrm{RMN}{ }^{13} \mathrm{C}$ $\left(\mathrm{CDCl}_{3}, 50 \mathrm{MHz}\right): 139,06 ; 114,19 ; 72,31 ; 66,78 ; 33,72 ; 33,12 ; 29,46,28,98 ; 28,81 ; 25,49$. IV (filme líquido): $v\left(\mathrm{~cm}^{-1}\right)=3360,2925,2850,2355,1630,1460,1070,910 \mathrm{~cm}^{-1}$. 


\subsection{3 - Reações enzimáticas}

\subsubsection{1 - Crescimento dos fungos}

Os fungos utilizados neste trabalho foram fungos de origem marinha, isolados das esponjas Chelonaplysilla erecta e Geodia corticostylifera, coletadas no Litoral Norte do Estado de São Paulo, em São Sebastião. Esses fungos fazem parte da coleção do Prof. Dr. Roberto G. de S. Berlinck (IQSC). Seu isolamento foi realizado pelo grupo da Profa. Dra Mirna H. R. Seleghim (UFSCar) e as cepas encontram-se depositadas no laboratório de Microbiologia da Universidade Federal de São Carlos. A identificação foi realizada pela Dra. Lara Durães Sette (curadora do CBMAI/CBQBA/UNICAMP).

Os microrganismos selecionados para as reações foram os fungos Penicillium miczynskii Gc5, Trichoderma sp. Gc1, Aspergillus sydowii Gc12 e Penicillium raistrickii Ce16.

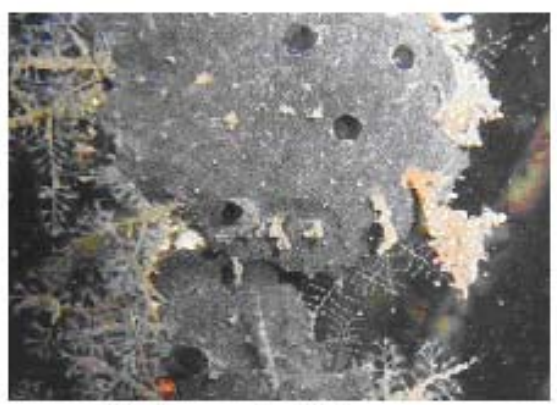

Chelonaplysilla enecta

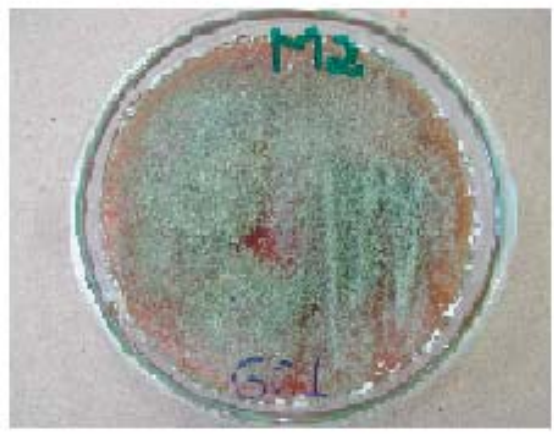

Trichoderma sp.

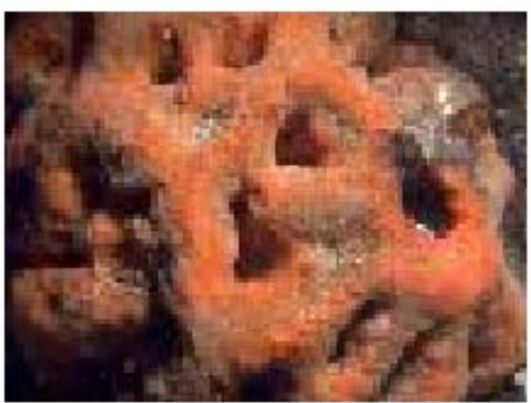

Geodia corticostylifent

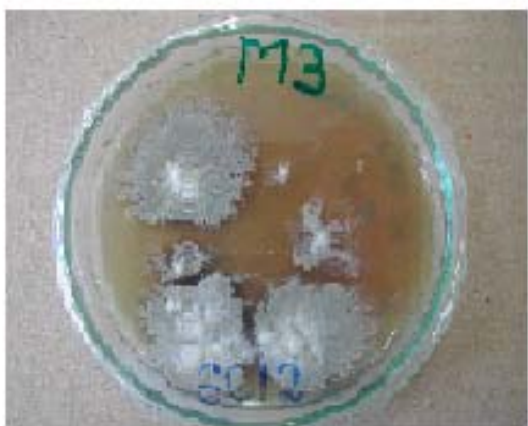

Aspergillus sydowii

Figura 18: Fotos das esponjas das quais os microrganismos foram isolados e dos fungos em meio de cultura sólido utilizados 
Preparou-se o meio de cultura para o cultivo dos fungos misturando-se em um Erlenmeyer de $2 \mathrm{~L}$ a água do mar artificial $(1 \mathrm{~L})$, o extrato de malte $(30 \mathrm{~g})$ e a peptona $(10 \mathrm{~g})$. A água do mar artificial foi preparada de acordo com os protocolos estabelecidos pelo grupo da Profa. Dra. Mirna H. R. Seleghim, misturando-se a um 1 L de água destilada, os seguintes sais: 1,36 g de cloreto de cálcio diidratado; 9,68 g de cloreto de magnésio hexaidratado; 0,61 g de cloreto de potássio; 30,0 g de cloreto de sódio; $0,14 \mathrm{mg}$ de fosfato de sódio bifásico anidro; 3,47 $\mathrm{g}$ de sulfato de sódio anidro; $0,17 \mathrm{~g}$ de bicarbonato de sódio; $0,1 \mathrm{~g}$ de brometo de potássio; $0,04 \mathrm{~g}$ de cloreto de estrôncio hexaidratado e $0,03 \mathrm{~g}$ de ácido bórico.

Esterilizou-se o meio de cultura líquido em autoclave por 15 minutos a $120{ }^{\circ} \mathrm{C}$ e em seguida resfriou-se à temperatura ambiente. O inóculo dos fungos em meio líquido foi realizado em uma capela de fluxo laminar. Os fungos foram previamente cultivados em meio sólido. Par 1 L de meio adicionou-se: $15 \mathrm{~g}$ de agar, $30 \mathrm{~g}$ extrato de malte e $3 \mathrm{~g}$ de peptona.

\subsubsection{2 - Síntese de dióis por biocatálise}

Após o crescimento dos microrganismos em meio líquido, as células foram filtradas em funil de Büchner e pesadas. Tanto as células quanto o caldo resultante da filtração foram utilizados nas reações de biocatálise.

\section{a) Reações com as células}

Em um Erlenmeyer de $250 \mathrm{~mL}$ adicionaram-se $100 \mathrm{~mL}$ de solução tampão fostato $\left(\mathrm{Na}_{2} \mathrm{HPO}_{4}\right.$ e $\left.\mathrm{KH}_{2} \mathrm{PO}_{4}\right) \mathrm{pH}=7$ e $5 \mathrm{~g}$ de células úmidas dos fungos. Em seguida, adicionaram-se 100 $\mu \mathrm{L}$ dos epóxidos 1-5 previamente dissolvidos em $400 \mu \mathrm{L}$ de dimetilsulfóxido (DMSO). 


\section{b) Reações com o caldo (meio de cultura)}

Em um Erlenmeyer de $250 \mathrm{~mL}$ adicionaram-se $100 \mathrm{~mL}$ do filtrado (caldo) e $100 \mu \mathrm{L}$ dos epóxidos 1-5 previamente dissolvidos em 400 $\mu \mathrm{L}$ de DMSO.

\section{c) Biotransformações no agitador rotativo}

Após o preparo das reações realizou-se as biotransformações em um agitador orbital $\left(32{ }^{\circ} \mathrm{C}, 150 \mathrm{rpm}\right) . \mathrm{O}$ monitoramento das reações foi realizado retirando-se alíquotas de $1 \mathrm{~mL}$, extraindo-se com acetato de etila e analisando-se por cromatografia gasosa.

\section{d) Hidrólise espontânea (branco)}

Em um Erlenmeyer de $250 \mathrm{~mL}$ adicionaram-se $100 \mathrm{~mL}$ de a- água destilada; b- água do mar artificial; c- solução malte $3 \%(\mathrm{~m} / \mathrm{v})$; d- solução tampão fosfato $(\mathrm{pH}=7)$ e $100 \mu \mathrm{L}$ de epóxido dissolvido em $400 \mu \mathrm{L}$ de DMSO. As reações foram realizadas em agitador orbital e analisadas por cromatografia a gás.

\section{e) Extração das reações}

Os produtos obtidos foram extraídos com acetato de etila. No caso das reações com as células dos fungos, essas foram filtradas em funil de Büchner antes da extração. À fase orgânica adicionou-se o sulfato de magnésio e posteriormente filtrou-se e o solvente foi removido no rotaevaporador. Os produtos obtidos foram purificados por cromatografia em coluna utilizandose sílica gel flash como fase estacionária e uma mistura éter de petróleo: acetato de etila - 1:1 como eluente. 


\section{2 - Síntese e resolução enzimática de cloroidrinas}

\subsection{1 - Síntese de cloroidrinas a partir de epóxidos racêmicos}

Em um Erlenmeyer de $250 \mathrm{~mL}$ adicionou-se $100 \mathrm{~mL}$ de água destilada, $1 \mathrm{~g}$ dos epóxidos (epóxidos 2-4, Figura 17) previamente dissolvidos em 2 mL de DMSO. Posteriormente, adicionaram-se $15 \mathrm{~g}$ de $\mathrm{NaCl}$. A reação foi mantida sob agitação à temperatura ambiente, sendo acompanhada por cromatografia em camada delgada, utilizando-se como eluente uma mistura de éter de petróleo-acetato de etila (1:1). Após o término da reação (5 dias), os produtos obtidos foram extraídos com acetato de etila. À fase orgânica foi adicionado sulfato de magnésio, em seguida filtrou-se e o solvente foi removido no rotaevaporador. Os produtos obtidos foram purificados por cromatografia em coluna, utilizando-se sílica gel flash como fase estacionária e uma mistura éter de petróleo: acetato de etila - 1:1 como eluente.

\subsection{2 - Síntese de acetatos por método químico}

Em um balão de fundo redondo de $50 \mathrm{~mL}$ foram adicionados $300 \mu \mathrm{L}$ de substrato (diol 2a, cloroidrina $4 \mathbf{b}$ ), $300 \mu \mathrm{L}$ de anidrido acético e $300 \mu \mathrm{L}$ de piridina. A reação foi mantida sob agitação à temperatura ambiente por $24 \mathrm{~h}$. Após seu término, adicionaram-se $10 \mathrm{~mL}$ de solução de $\mathrm{HCl} 10$ \% e extraiu-se com 10 mL de acetato de etila, sendo então o pH ajustado para 7 com solução de $\mathrm{KOH}$ 0,1 M. Adicionou-se sulfato de magnésio, posteriormente filtrou-se e em seguida removeu-se o solvente no rotaevaporador. Os acetatos foram purificados por cromatografia em coluna utilizando-se sílica gel flash como fase estacionária e uma mistura éter de petróleo: acetato de etila - 9:1 como eluente. 
As reações em menor escala foram realizadas sob as memsas condições, entretanto utilizaram-se 1,5 g NaCl, $10 \mathrm{~mL}$ de água , $100 \mu \mathrm{L}$ dos epóxidos 1-5 e $300 \mu \mathrm{L}$ de DMSO.

\subsection{3 - Caracterização das cloroidrinas e do acetato 4c por métodos espectroscópicos}

Os espectros obtidos para as cloroidrinas $\mathbf{2 b}, \mathbf{3 b}$ e $\mathbf{4 b}$ e para o acetato $\mathbf{4 c}$ encontram-se na Seção B, Anexos. Os compostos obtidos apresentaram as seguintes caracterizações:

(RS)- 1-cloro-2-propanol- 3-fenilmetóxi (2b)<smiles>ClCC(Cl)COCc1ccccc1</smiles>

Rendimento: $84 \%$. Líquido incolor. $\mathrm{RMN}^{1} \mathrm{H}$ $\left(\mathrm{CDCl}_{3}, 200 \mathrm{MHz}\right): \delta=7,59-7,33(\mathrm{~m}, 5 \mathrm{H})$; $4,65 \quad(\mathrm{~s}, \quad 2 \mathrm{H}) ; \quad 3,79-3,55 \quad(\mathrm{~m}, \quad 5 \mathrm{H})$ 2,14 (sl, 1H). $\mathrm{RMN}^{13} \mathrm{C}\left(\mathrm{CDCl}_{3}, 50 \mathrm{MHz}\right): 133,36 ; 128,47$ (2C); 127,94; 127,79 (2C); 73,62; 71,83; 70,62; 64,08. IV (filme líquido): $v\left(\mathrm{~cm}^{-1}\right)=3400,2900,2360,1720,1270,1090,710$.

(RS)- 1-cloro-2-propanol- 3-(4-metoxifenóxi) (3b)<smiles>COc1ccc(COCC(O)CCl)cc1</smiles>

Rendimento: $52 \%$. Sólido branco. p.f $=88{ }^{\circ} \mathrm{C}$ $\mathrm{RMN}{ }^{1} \mathrm{H}\left(\mathrm{CDCl}_{3}, 200 \mathrm{MHz}\right): \delta=6,85-6,84(\mathrm{~s}$, $4 \mathrm{H}) ; \quad 4,02-3,79 \quad(\mathrm{~m}, \quad 3 \mathrm{H}) ; \quad 3,77 \quad-\quad 3,76$ (m, 2H); 3,67 (s, 3H); 1,68 (sl, 1H). RMN ${ }^{13} \mathrm{C}\left(\mathrm{CDCl}_{3}, 50 \mathrm{MHz}\right): 154,37 ; 152,56 ; 115,58$ (2C); 114,72 (2C); 70,40; 70,05; 63,76; 55,74. IV (pastilha de KBr): $v\left(\mathrm{~cm}^{-1}\right)=3400,2910,2360,1500$, $1250,1032,809$. 
(RS)- 1-alilóxi-3-cloro-2-propanol (4b)<smiles>C=CCOCC(O)CCl</smiles>

Rendimento: 96\%. Líquido incolor. $\mathrm{RMN}{ }^{1} \mathrm{H}$ $\left(\mathrm{CDCl}_{3}, 200 \mathrm{MHz}\right): \delta=6,00-5,81(\mathrm{~m}, 1 \mathrm{H})$; $5,33-5,17 \quad(\mathrm{~m}, 2 \mathrm{H}) ; \quad 4,05-3,39$ (m, 7H); 2,20 (sl, 1H). RMN ${ }^{13} \mathrm{C}\left(\mathrm{CDCl}_{3}, 50 \mathrm{MHz}\right): 134,32 ; 117,69 ; 72,68 ; 71,80 ; 70,58 ; 64,53$. IV (filme líquido): $v\left(\mathrm{~cm}^{-1}\right)=3390,2900,2350,1730,1650,1415,1070$.

(RS)- 1-alilóxi-3-cloro-propan-2-il acetato (4c)

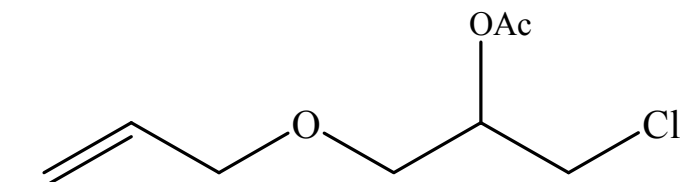

Rendimento: 68 \%. Líquido incolor. RMN ${ }^{1} \mathrm{H}\left(\mathrm{CDCl}_{3}, 200 \mathrm{MHz}\right): \delta=6,00-5,90(\mathrm{~m}$, $1 \mathrm{H}) ; 5,40-5,01(\mathrm{~m}, 2 \mathrm{H}) ; 4,60-4,40$ $(\mathrm{m}, \quad 1 \mathrm{H}) ; \quad 4,40 \quad-\quad 4,00 \quad(\mathrm{~m}, \quad 2 \quad \mathrm{H}) ; \quad 3,80-\quad 3,56 \quad(\mathrm{~m}, \quad 4 \quad \mathrm{H}) ; \quad 2,20 \quad(\mathrm{~s}, \quad 1 \mathrm{H})$.

\subsection{4 - Reações enzimáticas}

\section{a) Síntese do 1-alilóxi-3-cloro-propan-2-il acetato por biocatálise}

Em um Erlenmeyer de $50 \mathrm{~mL}$ foram adicionados $5 \mathrm{~mL}$ de hexano, $0,5 \mathrm{~mL}$ de acetato de vinila, $40 \mathrm{mg}$ da lipase comercial de Candida antartica B (Novozym ${ }^{\circledR}$ 435) e $40 \mu \mathrm{L}$ de 1 alilóxi-3-cloro-2-propanol (4a). A reação foi levada ao agitador orbital $\left(150 \mathrm{rpm}, 32{ }^{\circ} \mathrm{C}\right)$. O acompanhamento foi realizado retirando-se pequenas alíquotas e analisando-as por CG. Ao término da reação, evaporou-se o solvente no rotaevaporador. Os produtos obtidos foram purificados por cromatografia em coluna, utilizando-se sílica gel flash como fase estacionária e uma mistura de éter de petróleo:acetato de etila na proporção de 9,5:0,5 como eluente. 


\section{3 - Materiais e equipamentos utilizados}

\subsection{1 - Reagentes e solventes}

Os reagentes e solventes empregados foram obtidos de fontes comerciais (Aldrich e Fluka) e utilizados sem prévia purificação. Os sais utilizados também foram obtidos comercialmente (Synth, Merck e Vertec)

\subsection{2 - Cromatografia em coluna}

As cromatografias em coluna (CC) foram realizadas utilizando-se sílica gel flash 60 230-400 da Across e cromatofolhas de sílica gel $60 \quad \mathrm{~F}_{254}$ da Sorbent Technologies na cromatografia em camada delgada (CCD). As cromatofolhas foram reveladas com soluções de anisaldeído (100 mL de ácido acético, $1 \mathrm{~mL}$ de anisaldeído e $1 \mathrm{~mL}$ de ácido sulfúrico) ou de

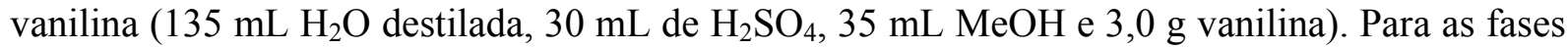
móveis foram determinadas as misturas de solventes mais adequadas em cada situação.

\subsection{3 - Espectroscopia de infravermelho (IV)}

Os espectros de absorção na região do infravermelho (IV) foram obtidos em um espectrofotômetro de infravermelho com transformada de Fourier Bomem/MB-102 e calibração interna. As amostras foram preparadas na forma de filmes (produtos líquidos) e em pastilhas de $\mathrm{KBr}$ (produtos sólidos) e as freqüências de absorção foram expressas em $\mathrm{cm}^{-1}$. 


\subsubsection{Espectroscopia de ressonância magnética nuclear (RMN)}

Os espectros de $\mathrm{RMN}^{1} \mathrm{H}$ e $\mathrm{RMN}{ }^{13} \mathrm{C}$ foram obtidos em espectrômetro Bruker/AC-200, que opera na freqüência de $200 \mathrm{MHz}$ e $50 \mathrm{MHz}$, respectivamente. O solvente utilizado foi clorofórmio deuterado $\left(\mathrm{CDCl}_{3}\right)$ e os deslocamentos químicos $(\delta)$ são expressos em parte por milhão (ppm) em relação ao padrão interno tetrametilsilano (TMS). A multiplicidade dos sinais observados está indicada pelas seguintes abreviaturas: $\mathrm{s}=$ singleto, $\mathrm{d}=$ dupleto, $\mathrm{t}=$ tripleto, $\mathrm{m}=$ multipleto, $\mathrm{dd}=$ duplo dupleto, $\mathrm{dt}=$ duplo tripleto. $\mathrm{O}$ número de hidrogênios foi deduzido pela integral relativa e a constante de acoplamento (J) é expressa em Hertz (Hz).

As análises de IV, $\mathrm{RMN}$ de ${ }^{1} \mathrm{H}$ e $\mathrm{RMN}{ }^{13} \mathrm{C}$ foram realizadas junto à Central Analítica do Instituto de Química de São Carlos (CAQI).

\subsection{5 - Polarímetro}

As medidas de rotação ótica foram realizadas no DQ-UFSCar em um Polarímetro Perkin-Elmer modelo 241 (Waltham MA, USA) equipado com lâmpada de $\mathrm{Na}(\lambda=589 \mathrm{~nm})$. As amostras foram diluídas em $1 \mathrm{~mL}$ de $\mathrm{CHCl}_{3}$ grau espectroscópico e os experimentos realizados a $25^{\circ} \mathrm{C}$. As análises foram realizadas no laboratório do Prof. Dr. Alcindo A. dos Santos.

\subsection{6 - Cromatografia a gás}

Os cromatogramas foram obtidos em um cromatógrafo a gás Heweltt Packard/5890. As colunas quirais utilizadas foram VARIAN WCOT Fused Sílica $25 \mathrm{~m}$ x 0,25 mm x 0,39 $\mu \mathrm{m}$, fase estacionária CP-Chirasil-Dex CB e VARIAN WCOT Fused Sílica $25 \mathrm{~m}$ x 0,25 mm x 0,39 $\mu \mathrm{m}$, fase estacionária CP-Ciclodextrina. $\mathrm{O}$ gás de arraste foi o hidrogênio. 
As condições de análise foram determinadas para cada composto. Primeiramente, os padrões racêmicos foram submetidos à CG para a determinação das melhores condições de separação dos seus enantiômeros. A programação utilizada para os diferentes substratos e produtos está descrita na Tabela 3.

Tabela 3. Programas utilizados no cromatógrafo a gás para a coluna quiral de ciclodextrinas

\begin{tabular}{ccccccc}
\hline Composto & $\mathbf{T}_{\mathbf{i}}\left({ }^{\circ} \mathbf{C}\right)$ & $\mathbf{t}_{\mathbf{i}}(\mathbf{m i n})$ & $\mathbf{T}_{\mathbf{f}}\left({ }^{\circ} \mathbf{C}\right)$ & $\mathbf{t}_{\mathbf{f}}(\mathbf{m i n})$ & $\mathbf{r}\left({ }^{\circ} \mathbf{C} / \mathbf{m i n}\right)$ & $\mathbf{t}_{\mathbf{r}}(\mathbf{m i n})$ \\
\hline $\mathbf{1}$ & 100 & 2 & 180 & 5 & 2 & $14,4 \mathrm{e} 14,6$ \\
$\mathbf{1 a}$ & 100 & 2 & 180 & 5 & 2 & 28,8 \\
$\mathbf{1 b}$ & 100 & 2 & 180 & 5 & 2 & $24,4 \mathrm{e} 24,6$ \\
$\mathbf{2}$ & 100 & 2 & 180 & 5 & 2 & $16,6 \mathrm{e} 16,8$ \\
$\mathbf{2 a}$ & 100 & 2 & 180 & 5 & 2 & 35 \\
$\mathbf{2 b}$ & 100 & 2 & 180 & 5 & 2 & 30 \\
$\mathbf{3}$ & 100 & 2 & 180 & 5 & 2 & 26 \\
$\mathbf{3 a}$ & 100 & 2 & 180 & 5 & 2 & 38 \\
$\mathbf{3 b}$ & 100 & 2 & 180 & 5 & 2 & 35 \\
$\mathbf{4}$ & 60 & 2 & 180 & 5 & 2 & $8,2 \mathrm{e} 8,4$ \\
$\mathbf{4 a}$ & 60 & 2 & 180 & 5 & 2 & 30,1 \\
$\mathbf{4 b}$ & 60 & 2 & 180 & 5 & 2 & $23,1 \mathrm{e} 23,3$ \\
$\mathbf{4 b}$ & 90 & 2 & 150 & 5 & 1 & $11,2 \mathrm{e} 11,4$ \\
$\mathbf{4 c}$ & 90 & 2 & 150 & 5 & 1 & $12,4 \mathrm{e} 13,7$ \\
$\mathbf{5}$ & 80 & 2 & 180 & 5 & 2 & $17,4 \mathrm{e} 17,5$ \\
$\mathbf{5 a}$ & 80 & 2 & 180 & 5 & 2 & 29,8 \\
\hline
\end{tabular}




\subsection{7 - Evaporadores rotativos}

Para a remoção dos solventes das soluções orgânicas foram utilizados os rota evaporadores Fisaton e Tecnal T - 210, ambos equipados com bomba de vácuo TE - 058 e refrigeração Tecnal Modelo TE - 2005.

\subsection{8 - Centrífuga}

As alíquotas retiradas das reações de biocatálise foram centrifugadas a $6000 \mathrm{rpm}$ e duração de 6 min em uma centrífuga modelo Hermle.

\subsection{9 - Agitador orbital rotativo termostatizado}

O crescimento dos fungos e as reações de biocatálise foram realizadas em agitador rotativo modelo Tecnal TE-421 ou Superohn.

\subsubsection{0 - Outros equipamentos utilizados}

Balança analítica modelo AY 220 - Suimadzu, capela de fluxo laminar marca Veco, autoclaves verticais modelo Phoenix e medidor de $\mathrm{pH}$ modelo 8010 da marca Qualxtron. 


\section{RESULTADOS E DISCUSSÕES}

\section{1 - Biotransformação de epóxidos racêmicos por microrganismos de origem marinha}

\subsection{1 - Síntese dos dióis racêmicos obtidos por método químico}

Os dióis racêmicos 1a-5a foram preparados a partir dos epóxidos racêmicos 1-5, conforme descrito anteriormente (Seção 3.1.1). As reações de abertura dos epóxidos foram facilmente realizadas e permitiram as sínteses dos dióis 1a-5a em bons rendimentos, Figura 19.

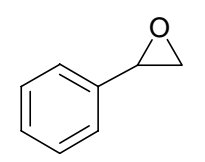

(RS) - 1<smiles>c1ccc(COCC2CO2)cc1</smiles>

$(R S)$ - 2<smiles>COc1ccc(OCC2CO2)cc1</smiles>

(RS) - 3

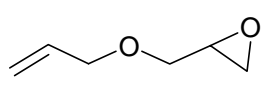

$(R S)-4$

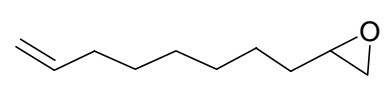

(RS) - 5

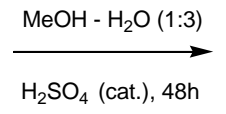

$\mathrm{H}_{2} \mathrm{SO}_{4}$ (cat.), $48 \mathrm{~h}$

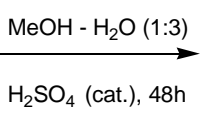

$\mathrm{H}_{2} \mathrm{SO}_{4}$ (cat.), $48 \mathrm{~h}$

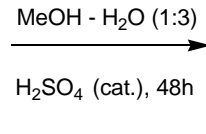

$\underset{\mathrm{H}_{2} \mathrm{SO}_{4} \text { (cat.), 48h }}{\stackrel{\mathrm{MeOH}-\mathrm{H}_{2} \mathrm{O}(1: 3)}{\longrightarrow}}$

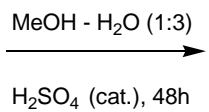<smiles>OCC(O)c1ccccc1</smiles>

(RS) - 1a

rendimento $79 \%$

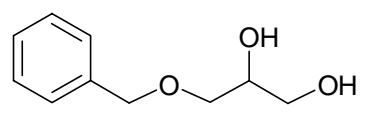

(RS) - $\mathbf{2 a}$

rendimento $85 \%$<smiles>COc1ccc(OCC(O)CO)cc1</smiles>

(RS) - $\mathbf{3 a}$

rendimento $89 \%$

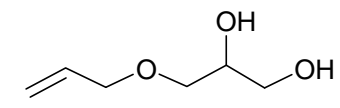

(RS) - $\mathbf{4 a}$

rendimento $68 \%$

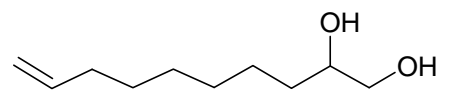

(RS) - $5 \mathbf{a}$

Figura 19. Dióis obtidos a partir da abertura de epóxidos em meio ácido 


\subsection{2 - Análise cromatográfica dos epóxidos e dos dióis racêmicos}

Os epóxidos comerciais foram analisados na coluna VARIAN WCOT Fused Sílica $25 \mathrm{~m} \times 0,25 \mathrm{~mm} \times 0,39 \mu \mathrm{m}$, fase estacionária CP-Chirasil-Dex CB. Os cromatogramas obtidos estão apresentados na Figura 20.

Pode-se observar que os enantiômeros dos epóxidos 1, 2, 4 e 5 foram resolvidos, pois existem dois picos correspondentes à separação enantiomérica. Os enantiômeros do epóxido 3, contudo, não foram resolvidos, pois há apenas um sinal para a mistura racêmica $(R S)$-3.

Os dióis 1a-5a foram analisados nas duas colunas quirais disponíveis no laboratório, mas nenhum apresentou a separação dos enantiômeros. Assim, métodos de derivatização, como a acetilação, foram empregados durante a realização deste trabalho para alguns compostos, pois os respectivos acetatos apresentaram uma boa resolução de seus enantiômeros em coluna quiral de $\beta$-ciclodextrina. Por exemplo, a reação de acetilação do diol 2a forneceu o produto diacetilado 2c e a cloroidrina $\mathbf{4 b}$ produziu o acetato 4c. Em ambos os casos os produtos acetilados 2c e 4c apresentaram discriminação de seus enantiômeros em coluna quiral (Figuras 30 e 39). 


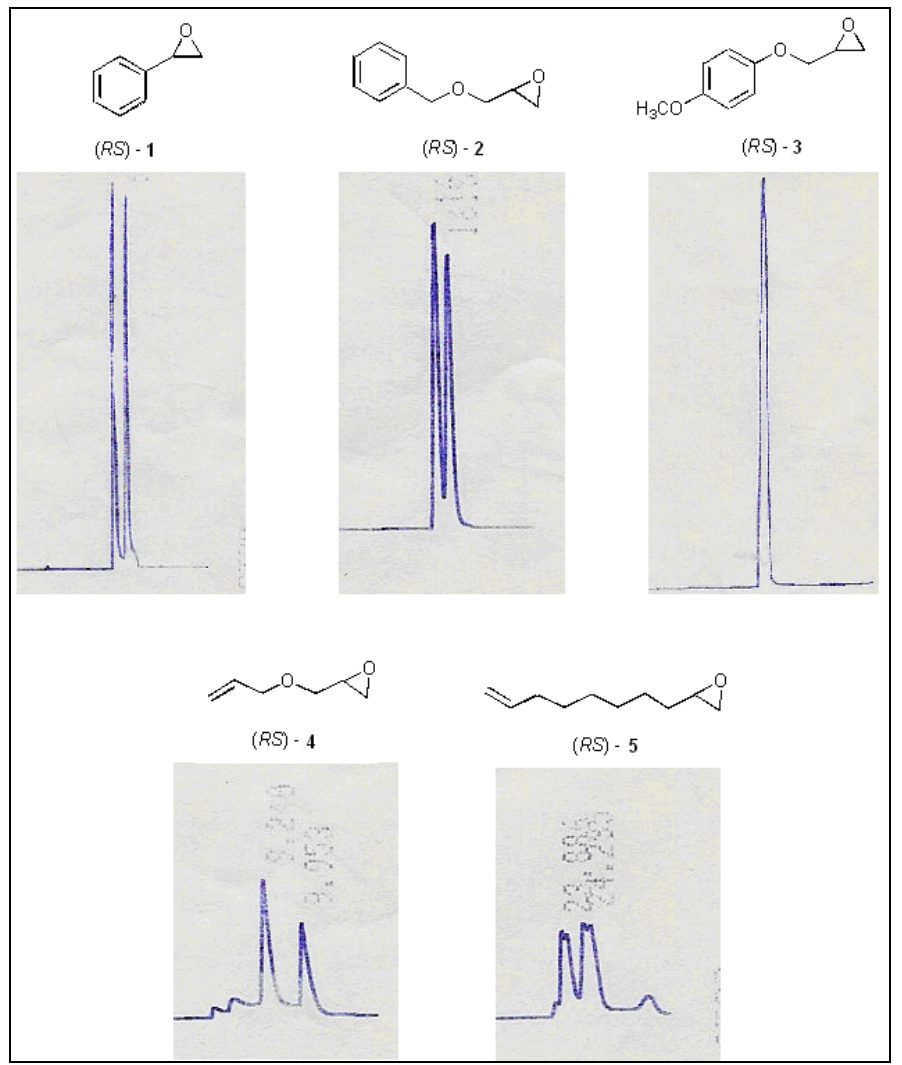

Figura 20. Cromatogramas dos epóxidos racêmicos comerciais

Como o (RS)-2-(benziloximetil)oxirano (2) apresentou uma boa resolução enantiomérica na coluna quiral de $\beta$-ciclodextrina, esse foi selecionado para a triagem com os fungos nas reações de biocatálise. Inicialmente, realizou-se a análise do respectivo diol (RS)-2a, obtido por método químico para verificar seu tempo de retenção no cromatograma (Figura 21).

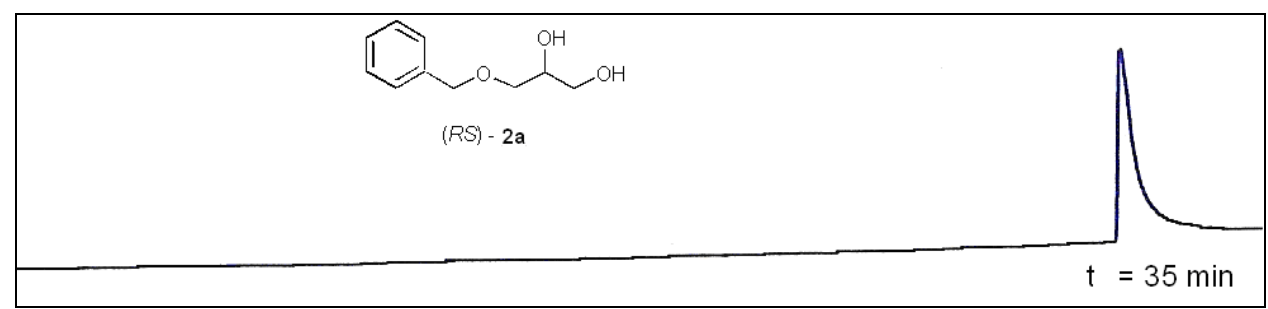

Figura 21. Cromatograma do diol $(R S)$-2a obtido por método químico 
Realizaram-se também os brancos das reações do epóxido 2 em i- água destilada; iiágua do mar artificial; iii- água destilada + malte $(3 \% \mathrm{~m} / \mathrm{v})$ e iv- solução tampão fosfato $(\mathrm{pH}=$ 7) a fim de observar o comportamento do epóxido (RS)-2 nos diferentes meios empregados nas reações biocatalisadas. Para os sistemas i, iii e iv não se observou a abertura espontânea do epóxido (RS)-2 o qual apresentou um tempo de retenção entre 16,7-16,9 minutos (Figura 22). Contudo, em água do mar artificial observou-se a formação de um produto com tempo de retenção em 30 minutos, portanto foi distinto do epóxido (RS)-2 e do seu respectivo diol (RS)-2a (Figura 23).

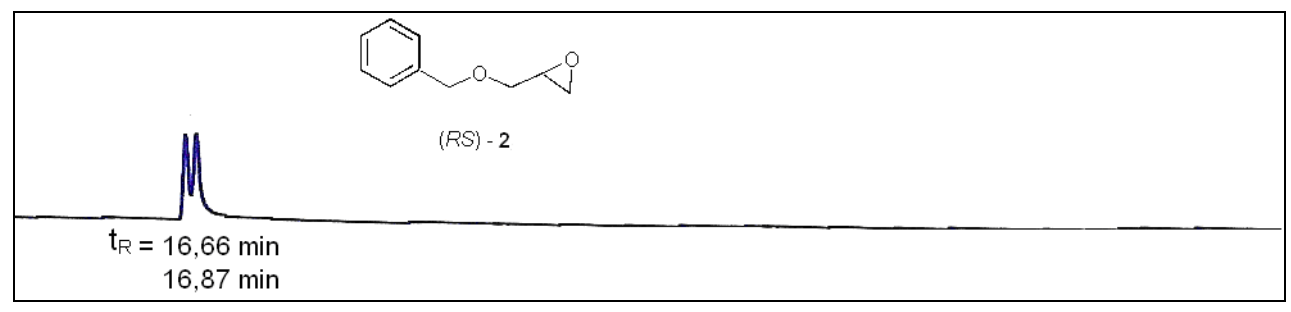

Figura 22. Cromatograma do epóxido $(R S)-2$ em água destilada; água destilada + malte; tampão fosfato $(\mathrm{pH}=7)$

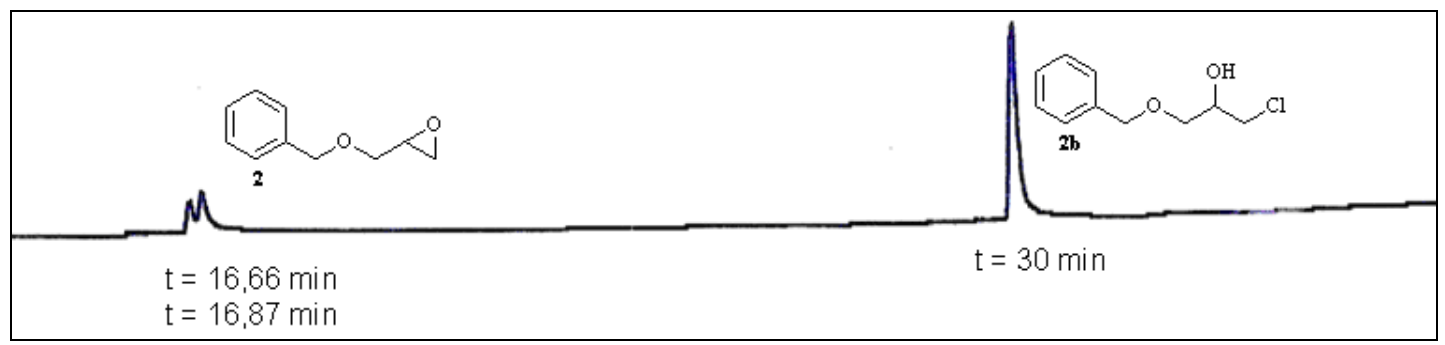

Figura 23. Cromatograma da cloroidrina $(R S)$-2b obtida em água do mar artificial a partir do epóxido $(R S)-2$

A reação em água do mar foi realizada em triplicata para se isolar e caracterizar o produto formado (Figura 24). Após análise dos espectros por $\mathrm{RMN}{ }^{1} \mathrm{H}$ e ${ }^{13} \mathrm{C}$ concluiu-se que o produto obtido foi a cloroidrina $(R S)-2 \mathbf{b}$, com rendimento de $84 \%$ após purificação por cromatografia em coluna. 


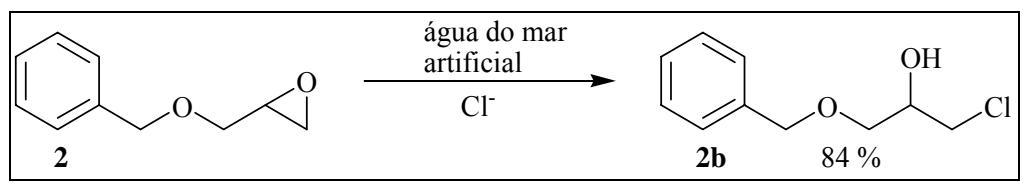

Figura 24. Síntese de cloroidrina $\mathbf{2 b}$ via água do mar artificial

Portanto, concluiu-se que seria inviável realizar a reação de hidrólise do epóxido (RS)-2 com o caldo dos fungos cultivados em água do mar artificial, devido à formação espontânea da cloroidrina (RS)-2b. Assim, decidiu-se por realizar as reações de biocatálise utilizando-se apenas as células íntegras dos microrganismos.

A formação da cloroidrina (RS)-2b a partir da abertura do epóxido (RS)-2 na água do mar demonstrou ser uma reação interessante para a obtenção de cloroidrinas a partir de epóxidos, apresentando inclusive um bom rendimento. Vale ressalvar a simplicidade da metodologia empregada, como o uso de reagente e solvente (sais de $\mathrm{Cl}^{-}$e água) de baixo custo e toxicidade. Assim, otimizaram-se as condições reacionais para a formação de cloroidrinas $\mathbf{1 b}-\mathbf{5 b}$ a partir dos epóxidos racêmicos 1-5 a fim de sintetizar as cloroidrinas.

\subsection{3 - Triagem dos microrganismos}

Foram selecionados quatro fungos para serem utilizados nas reações de biocatálise: Penicillium miczynskii Gc5, Trichoderma sp. Gc1, Aspergillus sydowii Gc12 e Penicillium raistrickii Ce16. As reações foram realizadas como descrito na Seção 3.1.3.2, utilizando-se o epóxido $(R S)$-2 na presença das células totais dos fungos cultivados em água do mar.

Para as reações com os fungos Penicillium miczynskii Gc5 e Penicillium raistrickii Ce16, não foi observada nenhuma transformação biocatalisada, indicando que esses fungos não devem conter epóxido hidrolases capazes de converter o epóxido(RS)- 2 em seu respectivo diol 
(RS)-2a. Enquanto os fungos Trichoderma sp. Gc1 e Aspergillus sydowii Gc12 catalisaram a formação do diol 2a com tempo de retenção de 35 minutos (Figuras 25 e 26).

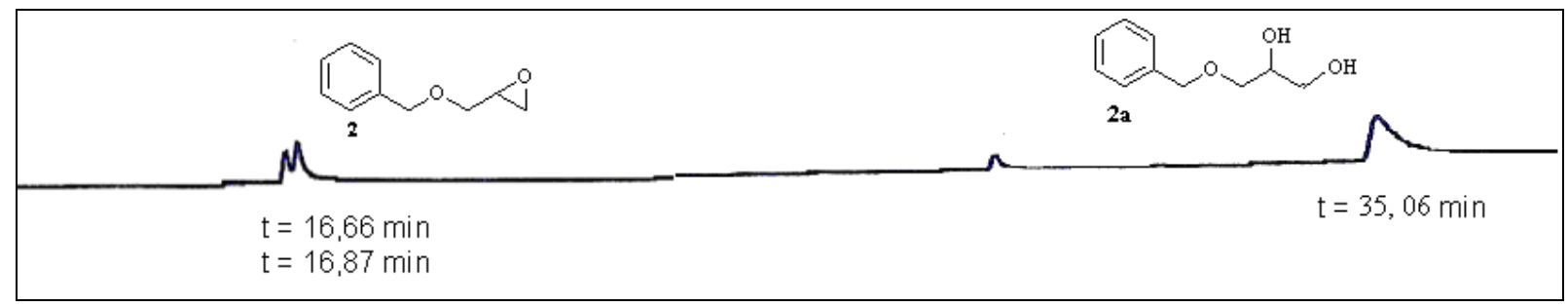

Figura 25. Cromatograma para a reação do epóxido 2 com o fungo Aspergillus sydowii Gc12 (5 dias)

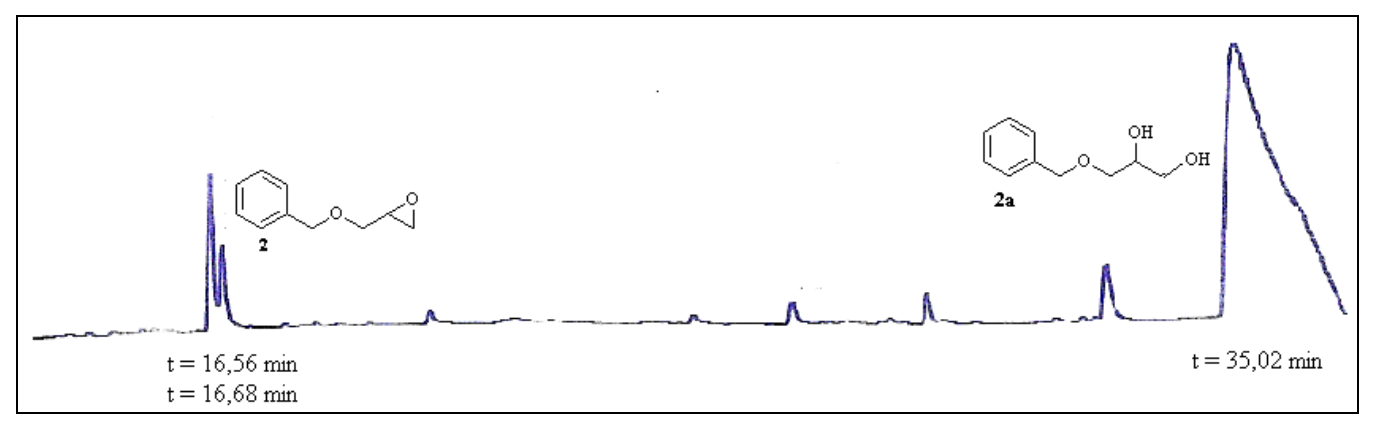

Figura 26. Cromatograma para a reação do epóxido 2 com o fungo Trichoderma sp. Gc1 (5 dias)

Reações de hidrólise do epóxido 2 com o fungo Aspergillus sydowii Gc12

Pode-se observar pelas análises dos cromatogramas (Figura 27) que o epóxido (RS)-2 foi parcialmente biotransformado no diol 2a. Após 120 h de reação realizou-se a extração e a purificação dos compostos obtendo-se um rendimento de $32 \%$ para o diol 2a. Neste caso observou-se uma preferência na hidrólise do epóxido $(R)-2$ e o epóxido $(S)-2$ não hidrolisado foi obtido com excesso enantiomérico de $46 \%$ (Tabela 4). 


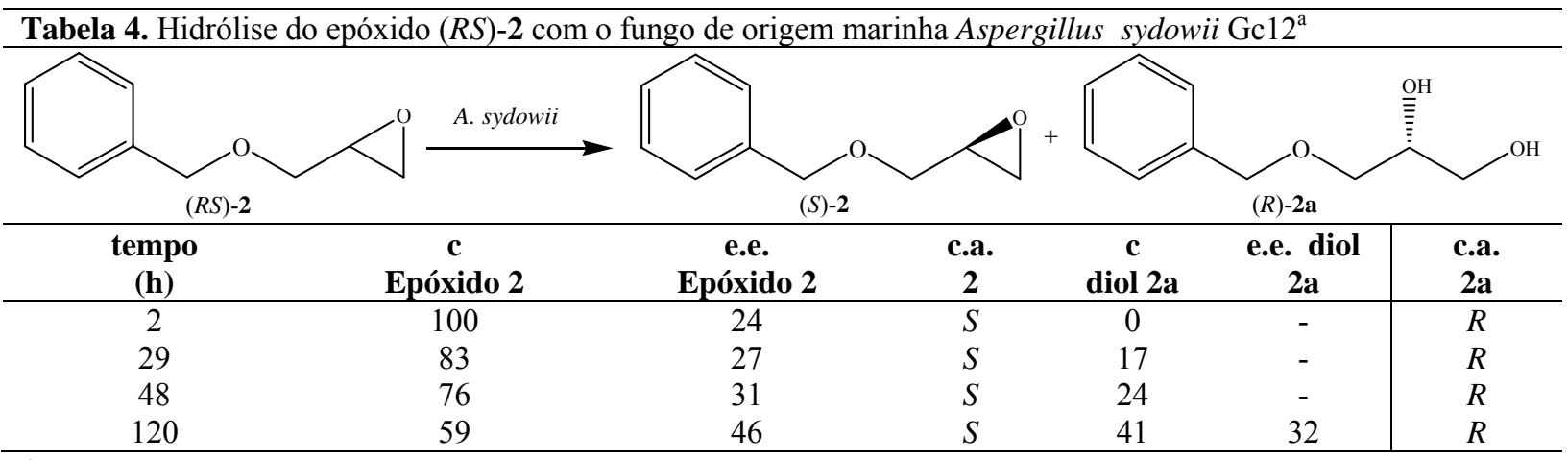

${ }^{\mathrm{a} C}$ Condições de reação: $5 \mathrm{~g}$ de massa celular de fungo; $100 \mathrm{mg}$ de epóxido 2; $400 \mu \mathrm{L}$ de DMSO; $150 \mathrm{rpm}$; $32{ }^{\circ} \mathrm{C}$; c

$(\%)=$ concentração determinada por CG; e.e. $(\%)=$ excesso enantiomérico; c.a. = configuração absoluta

- 2 horas de reação

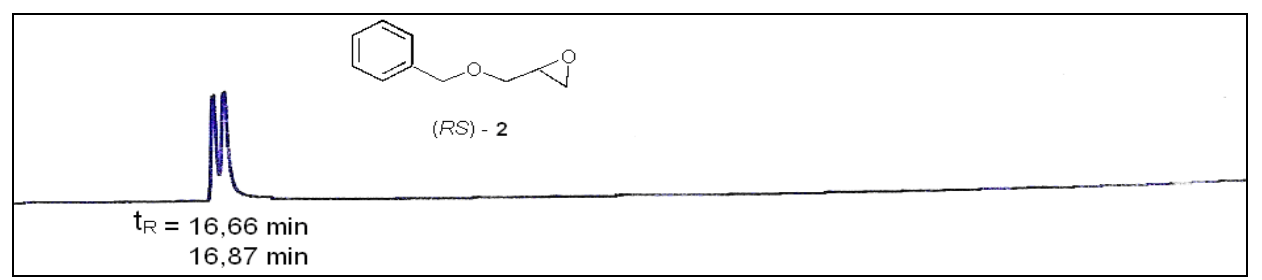

- 29 horas de reação

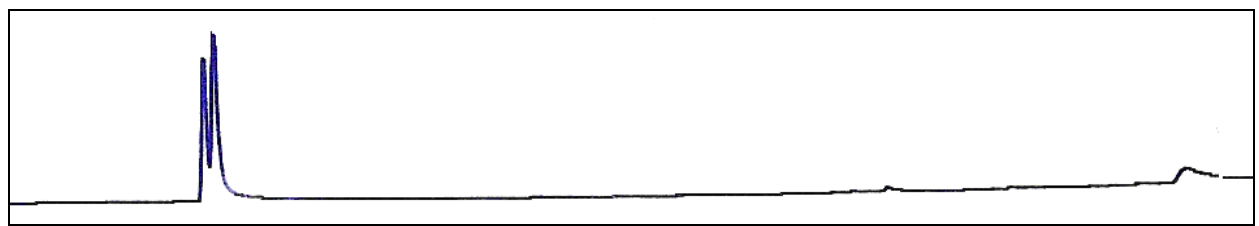

- 48 horas de reação

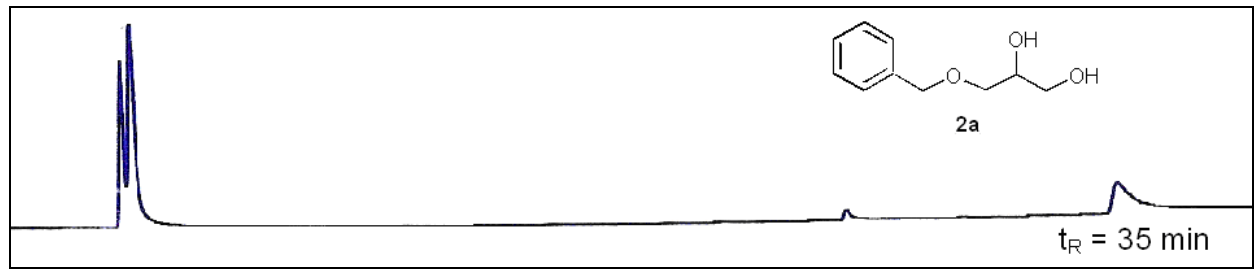

- 120 horas de reação

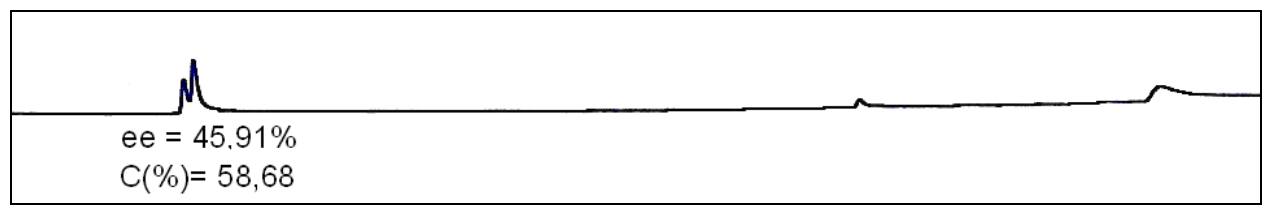

Figura 27. Cromatogramas para a reação do epóxido 2 com as células do fungo Aspergillus sydowii Gc12 


\section{Reações de hidrólise do epóxido 2 com o fungo Trichoderma sp. Gc1}

Pode-se observar pelas análises dos cromatogramas (Figura 28) que com 9 h de reação ocorreu uma boa hidrólise do epóxido 2 formando o diol 2a. Nesse caso, ocorreu uma preferência na hidrólise por um dos enantiômeros do epóxido (9-23 h de reação), mas ao término da reação (47 h) ambos os enantiômeros foram hidrolisados indistintamente. O diol 2a foi obtido com rendimento de 61 \% para um tempo de reação de 47 h. O diol (S)-2a foi obtido com excesso enantiomérico de 32 \% após derivatização no diacetato 2c (Seção 4.1.4.3).

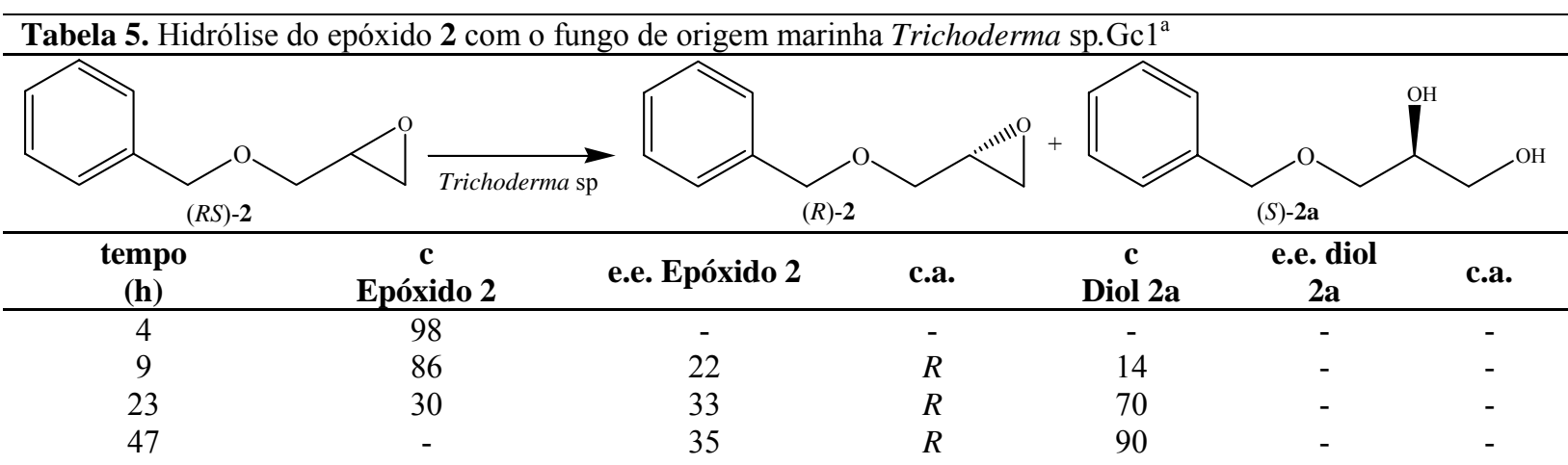

${ }^{\text {a }}$ condições de reação: $5 \mathrm{~g}$ de massa celular de fungo; $100 \mathrm{mg}$ de epóxido 2; $400 \mu \mathrm{L}$ de DMSO; 150 rpm; $32{ }^{\circ} \mathrm{C}$; c $(\%)=$ concentração determinada por CG; e.e. $(\%)=$ excesso enantiomérico; c.a. = configuração absoluta

- 4 horas de reação

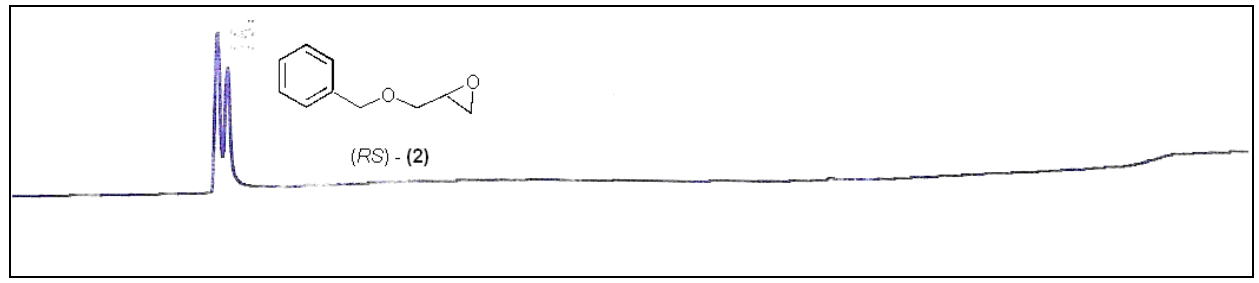

- 9 horas de reação

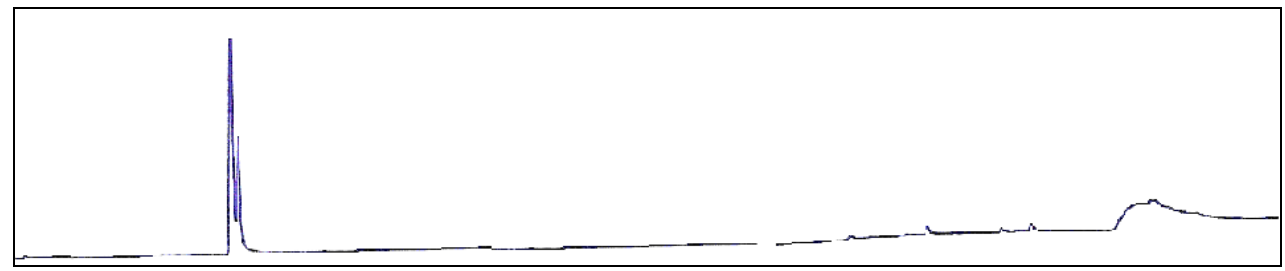




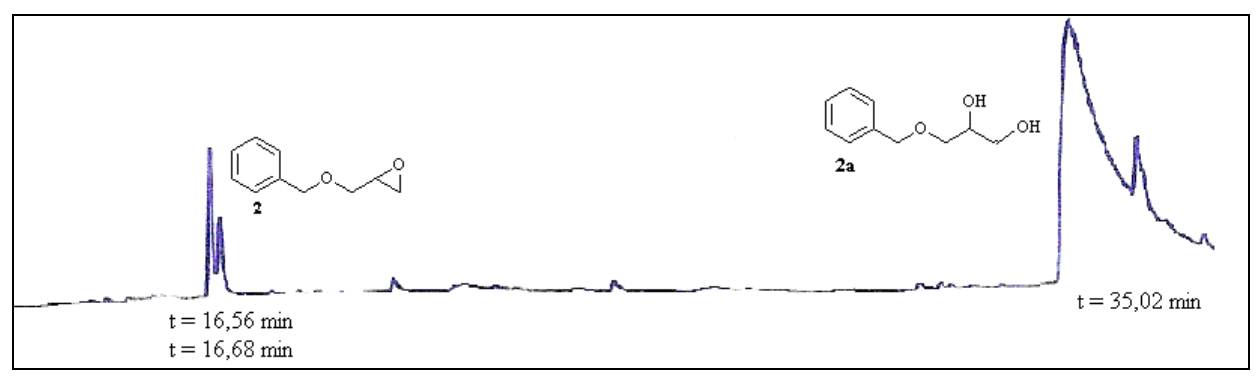

- 47 horas de reação

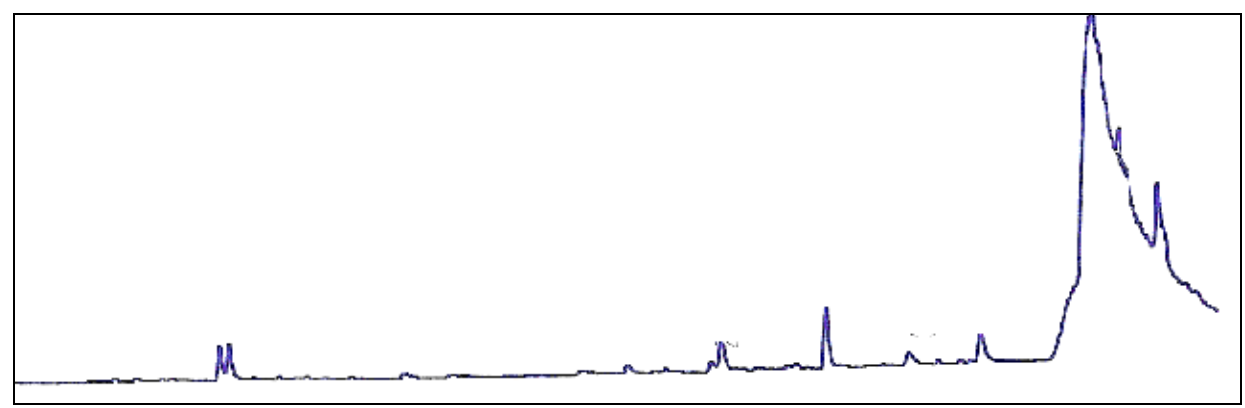

Figura 28. Cromatogramas para a reação do epóxido 2 com as células do fungo Trichoderma sp.Gc1

Concluiu-se que o fungo Trichoderma sp. Gc1 apresentou resultados enantiocomplementares com o fungo Aspergillus sydowii Gc12 para a reação de hidrólise do epóxido (RS)-2. A epóxido hidrolase do Trichoderma sp. Gc1 teve preferência em hidrolisar o $(R)-2$ epóxido, enquanto que a epóxido hidrolase do fungo A. sydowii teve preferência pela hidrólise do (S)-2. Portanto as reações com ambos os fungos permite obter todos os possíveis enantiômeros tanto do diol 2a $(R$ e $S)$ quanto do epóxido 2 ( $R$ e $S$ ) embora com modestas purezas enantioméricas (Figura 28 a).

Dessa forma, decidiu-se otimizar as condições experimentais da reação do epóxido (RS)-2 com o fungo Trichoderma sp. Gc1 com o objetivo de se obter tanto o epóxido 2 quanto o diol 2a com melhores rendimentos e excessos enantioméricos. 


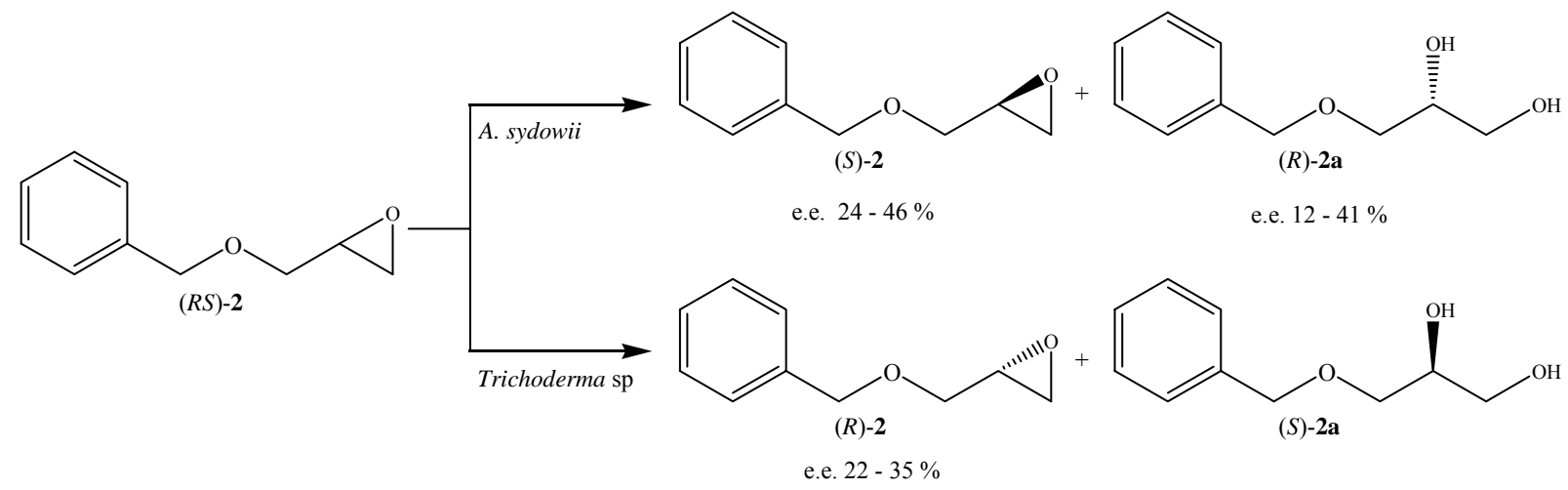

Figura 28a. Enantio-complementariedade na hidrólise do epóxido (RS)-2 com os fungos A. sydowii e Trichoderma sp

\subsection{4 - Otimização das reações de hidrólise do epóxido (RS)-2 com o fungo Trichoderma sp}

\subsubsection{1 - Crescimento do microrganismo na ausência de íons cloreto}

Como discutido anteriormente, a conversão espontânea do epóxido 2 em presença de íons cloreto na respectiva cloroidrina $\mathbf{2 b}$ impossibilitou realizar as reações com o caldo enzimático dos fungos cultivados em água do mar artificial. Assim, realizou-se crescimento do fungo Trichoderma sp. Gc1 contendo somente água destilada (1 L) e os meios de cultura de extrato de malte (30 g) e peptona (10 g). Entretanto, após realizar as reações com as células totais e o caldo enzimático do fungo cultivado na ausência de íons cloreto não apresentou atividade catalítica. Portanto, a presença de sais que constituem a composição da água do mar artificial promove de alguma forma produção ou ativação das enzimas epóxido-hidrolases, que são responsáveis pelas reações de abertura de epóxidos. Dessa forma, concluiu-se que o fungo Trichoderma sp. Gc1 deve ser cultivado em água do mar artificial, entretanto o caldo resultante da filtração não deve ser utilizado nas reações. 


\subsubsection{2 - Variação da massa de biocatalisador na resolução enzimática do epóxido (RS)-2}

Foram realizados experimentos variando-se a quantidade de massa celular úmida do fungo Trichoderma sp. Gc1 nas reações de hidrólise para o epóxido 2, sob as mesmas condições reacionais descritas anteriormente. As reações foram monitoradas periodicamente e analisadas por CG. Os resultados obtidos estão sumarizados na Tabela 6.

Tabela 6. Hidrólise do epóxido 2 com o fungo de origem marinha Trichoderma sp. Gc1 ${ }^{\mathrm{a}}$

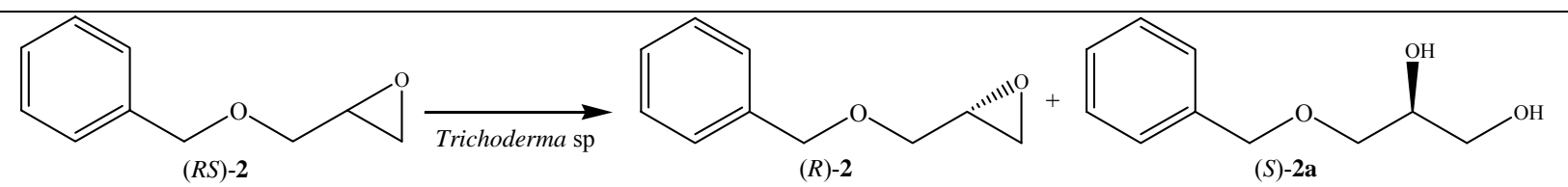

$(R S)-2$

$(R)-2$

$(S)-\mathbf{2 a}$

Massa úmida de fungo Trichoderma sp. Gc1 (3 g )

\begin{tabular}{|c|c|c|c|c|c|}
\hline $\begin{array}{c}\text { tempo } \\
\text { (h) }\end{array}$ & $\begin{array}{c}\text { c } \\
\text { epóxido } 2\end{array}$ & e.e. epóxido 2 & c.a. & $\begin{array}{c}c \\
\text { diol } 2 a \\
\end{array}$ & c.a. \\
\hline 4 & 98 & 1 & $R$ & 2 & $S$ \\
\hline 19 & 72 & 7 & $R$ & 28 & $S$ \\
\hline 25 & 63 & 16 & $R$ & 37 & $S$ \\
\hline 47 & 39 & 21 & $R$ & 61 & $S$ \\
\hline 70 & 12 & - & $R$ & 88 & $S$ \\
\hline
\end{tabular}

Massa úmida de fungo Trichoderma sp. Gc1 (5 g )

\begin{tabular}{ccccc}
\hline $\begin{array}{c}\text { tempo } \\
\text { (h) }\end{array}$ & $\begin{array}{c}\text { c } \\
\text { epóxido 2 }\end{array}$ & $\begin{array}{c}\text { e.e. } \\
\text { epóxido 2 }\end{array}$ & $\begin{array}{c}\text { c.a. } \\
\text { c.a. }\end{array}$ \\
\hline 4 & 95 & 3 & $R$ & 5 \\
19 & 59 & 45 & $R$ & 41 \\
25 & 48 & 60 & $R$ & 5 \\
47 & 22 & 8 & $R$ & $S$ \\
70 & 7 & - & $R$ & $S$ \\
\hline
\end{tabular}

Massa úmida de fungo Trichoderma $s p . \mathrm{Gc1}(8 \mathrm{~g})$

\begin{tabular}{ccccc}
\hline $\begin{array}{c}\text { tempo } \\
\text { (h) }\end{array}$ & $\begin{array}{c}\text { c } \\
\text { epóxido 2 }\end{array}$ & $\begin{array}{c}\text { e.e. } \\
\text { epóxido 2 }\end{array}$ & c.a. & $\begin{array}{c}\text { c.a. } \\
\text { diol 2a }\end{array}$ \\
\hline 4 & 98 & 1 & $R$ & 2 \\
19 & 76 & 21 & $R$ & 24 \\
25 & 59 & 38 & $R$ & $S$ \\
47 & 32 & 6 & $R$ & $S$ \\
70 & 26 & - & $S$ & $S$ \\
\hline
\end{tabular}

${ }^{\mathrm{a}}$ Condições de reação: $5 \mathrm{~g}$ de massa celular de fungo; $100 \mathrm{mg}$ de epóxido 2; $400 \mu \mathrm{L}$ de DMSO;

$150 \mathrm{rpm} ; 32^{\circ} \mathrm{C} ; \mathrm{c}(\%)=$ concentração determinada por CG; e.e. $(\%)=$ excesso enantiomérico. 
Como pode ser observado na Tabela 6 na reação em que se utilizou 5 g de células do fungo Trichoderma sp.Gc1 apresentou o melhor resultado para a hidrólise do epóxido 2, tendo os maiores valores de excessos enantioméricos para o $(R)$-2 (e.e. 45-60\%) e para o $(S)$-2a (e.e. 41$52 \%)$ no intervalo entre 19 e 25 horas. A diminuição ou o aumento na quantidade de biocatalisador não resultaram em maiores valores de excessos enantioméricos para o epóxido 2 para concentrações próximas de $50 \%$. Observa-se também que após $47 \mathrm{~h}$ de reação houve praticamente uma hidrólise total do epóxido. Assim, concluiu-se que a massa de $5 \mathrm{~g}$ de fungo foi ideal para as reações de biocatálise envolvendo abertura do epóxido 2. Devido a reação envolver um hidrólise enzimática a partir de uma mistura de enantiômeros de (RS)-2 a conversão ideal seria de $50 \%$, tanto para o epóxido 2 remanescente quanto para o diol 2a obtido. Neste caso o intervalo de 19-25 horas foi o mais apropriado para obter a melhor resolução enzimática, contudo os produtos desta reação não possuem elevadas purezas enantioméricas, como ficou comprovado nestes estudos realizados.

\subsubsection{3 - Variação do tempo de reação de hidrólise}

Depois de otimizadas as condições de reação descritas anteriormente, realizou-se as reações em triplicata, com um tempo de 25 h, para fazer o isolamento do epóxido 2 e o diol 2a para determinar o rendimento, a configuração dos produtos e o excesso enantiomérico do diol 2a. A Figura 29 apresenta o cromatograma bruto da hidrólise enzimática com células totais do fungo Trichoderma sp. Gc1 após 25 h de reação. 


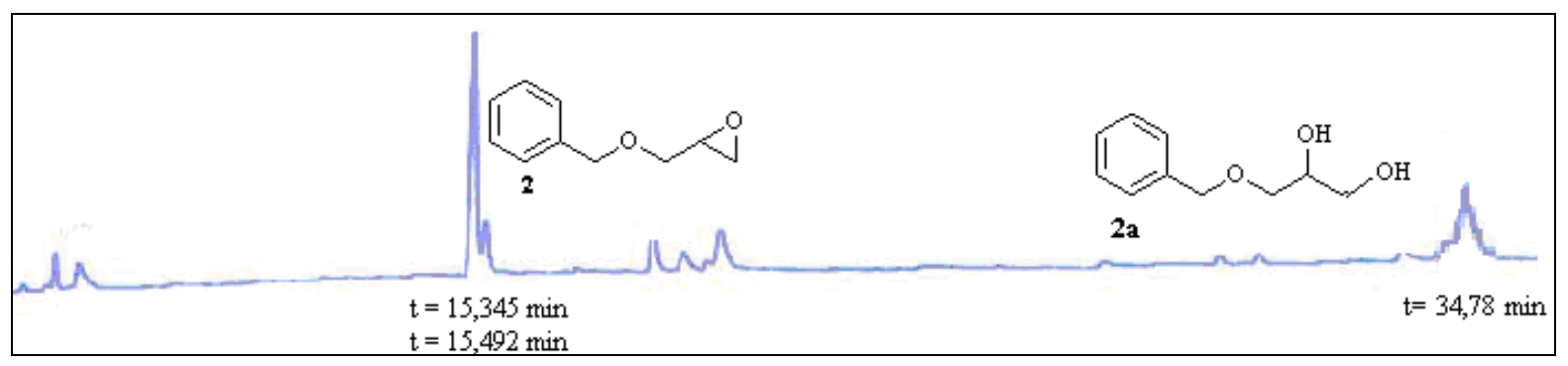

Figura 29. Cromatograma da hidrólise do epóxido $(R S)-2$ com o fungo Trichoderma sp.Gc1 em 25 h de reação

Na Figura 29 oberva-se a hidrólise preferencial de um dos enantiômeros do epóxido 2 com a formação do respectivo diol 2a. Os produtos obtidos foram purificados por cromatografia em coluna fornecendo $39 \%$ de rendimento do epóxido 2 e pureza enantiomérica de $60 \%$, enquanto que o diol 2a foi obtido rendimento de $15 \%$. O baixo rendimento do diol $2 \mathbf{a}$, pode ser devido à dificuldade na etapa de extração, pois os dois grupos hidroxilas presentes no composto aumenta sua solubilidade na fase aquosa. Inclusive nas análises das reações observa-se uma dificuldade de detecção do diol 2a por CG. Para calcular o excesso enantiomérico do diol 2a realizou-se a derivatização através de uma reação de diacetilação, obtendo o respectivo diacetato 2c (Figura 30). Felizmente este diacetato 2c apresentou uma ótima separação enantiomérica na coluna quiral de $\beta$-ciclodextrina utilizada. A Figura 31 apresenta o cromatograma por CG quiral para a síntese do respectivo acetato 2c proveniente do diol 2a obtido na reação de hidrólise com o fungo Trichoderma sp Gc1. O mesmo procedimento foi realizado para o padrão racêmico do diacetato $(R S)-\mathbf{2 c}$. 


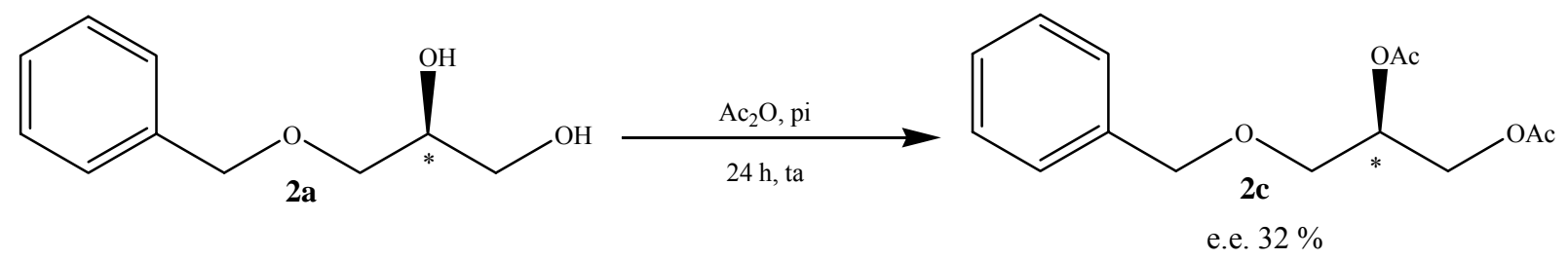

Figura 30. Conversão do diol 2a em seu respectivo acetato 2c

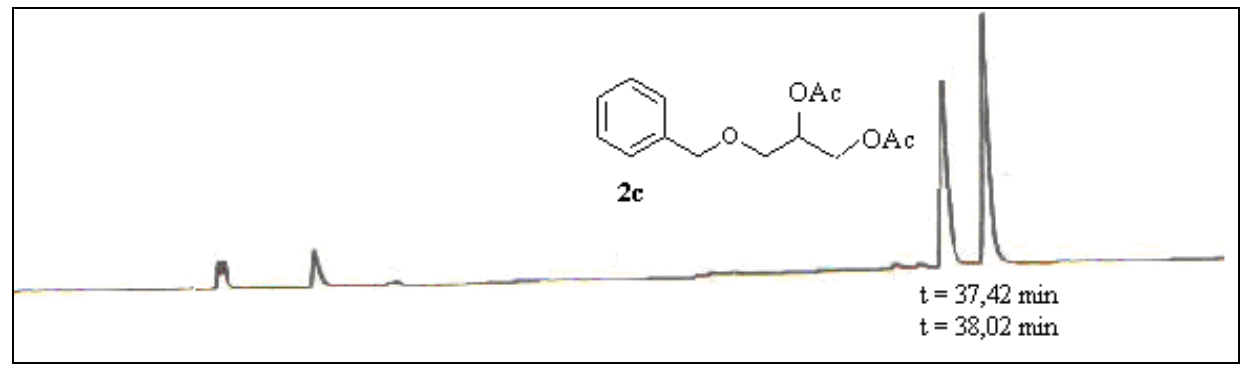

Figura 31. Cromatograma da esterificação do diol 2a após 25 h de reação

Como observado na Figura 31, os enantiômeros do composto 2c foram resolvidos, permitindo o cálculo do seu excesso enantiomérico, obtendo-se o valor de $32 \%$. Assim, pode-se concluir que o diol 2a foi obtido com uma pureza enantiomérica relativamente baixa do valor desejável que é $>98 \%$, mesmo sob condições otimizadas. O controle na abertura do anel oxirano na presença de células totais de microrganismos é bastante difícil, pois os epóxidos de forma geral são facilmente hidrolisados, resultado em produtos com modestas purezas enantioméricas. Medidas de rotação ótica foram realizadas em um polarímetro a fim de se determinarem as configurações absolutas do epóxido 2 e do diol 2a obtidos na reação (Tabela 7). 
Tabela 7. Medidas de rotação ótica para o epóxido 2 e o diol 2a obtidos na reação de biocatálise com o fungo Trichoderma sp.Gc1 [39]

$[\alpha]_{\mathrm{D} \text { experimental }}^{25}$
$-23,12^{\circ}\left(c 2.0, \mathrm{CHCl}_{3}\right)$
$\begin{gathered}(\mathrm{D}) \\ (\mathrm{D} \text { literatura }\end{gathered}$

Assim, concluiu-se que o fungo Trichoderma sp.Gc1 converteu seletivamente o epóxido (S)-2 no diol (S)-2a com retenção da configuração absoluta. O ataque do nucleófilo $\mathrm{OH}^{-}$ocorreu no carbono menos substituído do anel oxirano durante a reação enzimática de hidrólise, gerando os produtos heteroquirais, o epóxido $(R)-2$ e diol (S)-2a. Na Figura 31a tem a abertura seletiva do epóxido (RS)-2 com fungo Trichoderma sp.Gc1.<smiles>c1ccc(COCC2CO2)cc1</smiles>

(S)-2

e.e. $60 \%$
rendimento $39 \%$

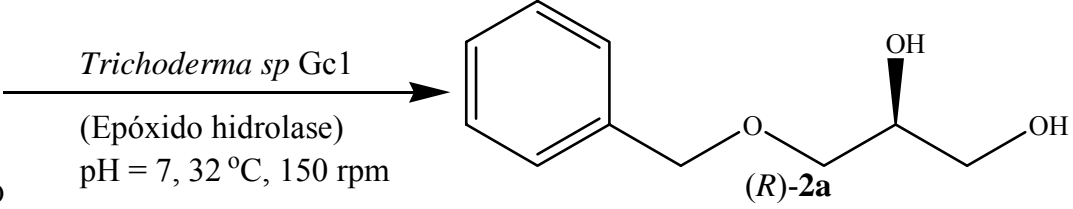

$(R)-2$

e.e. $32 \%$

rendimento $15 \%$

Figura 31a. Hidrólise seletiva do (RS)-2a com o fungo Trichoderma sp GC1

A partir dos resultados obtidos para a biotransformação do epóxido 2 com o fungo Trichoderma sp.Gc1, foram realizadas as reações de hidrólise com os epóxidos 3, 4 e 5, utilizando-se as condições experimentais otimizadas a fim de se observar os comportamentos dos de diferentes substratos frente a epóxido hidrolase do fungo Trichoderma sp.Gc1. 


\subsection{5 - Reações de biocatálise dos epóxidos 1-5 com o microrganismo Trichoderma sp.Gc1}

Inicialmente foram realizadas as análises por CG quiral dos dióis racêmicos 1a-5a, obtidos por método químico para verificar seus tempos de retenção. Os cromatogramas das análises encontram-se na Figura 32.
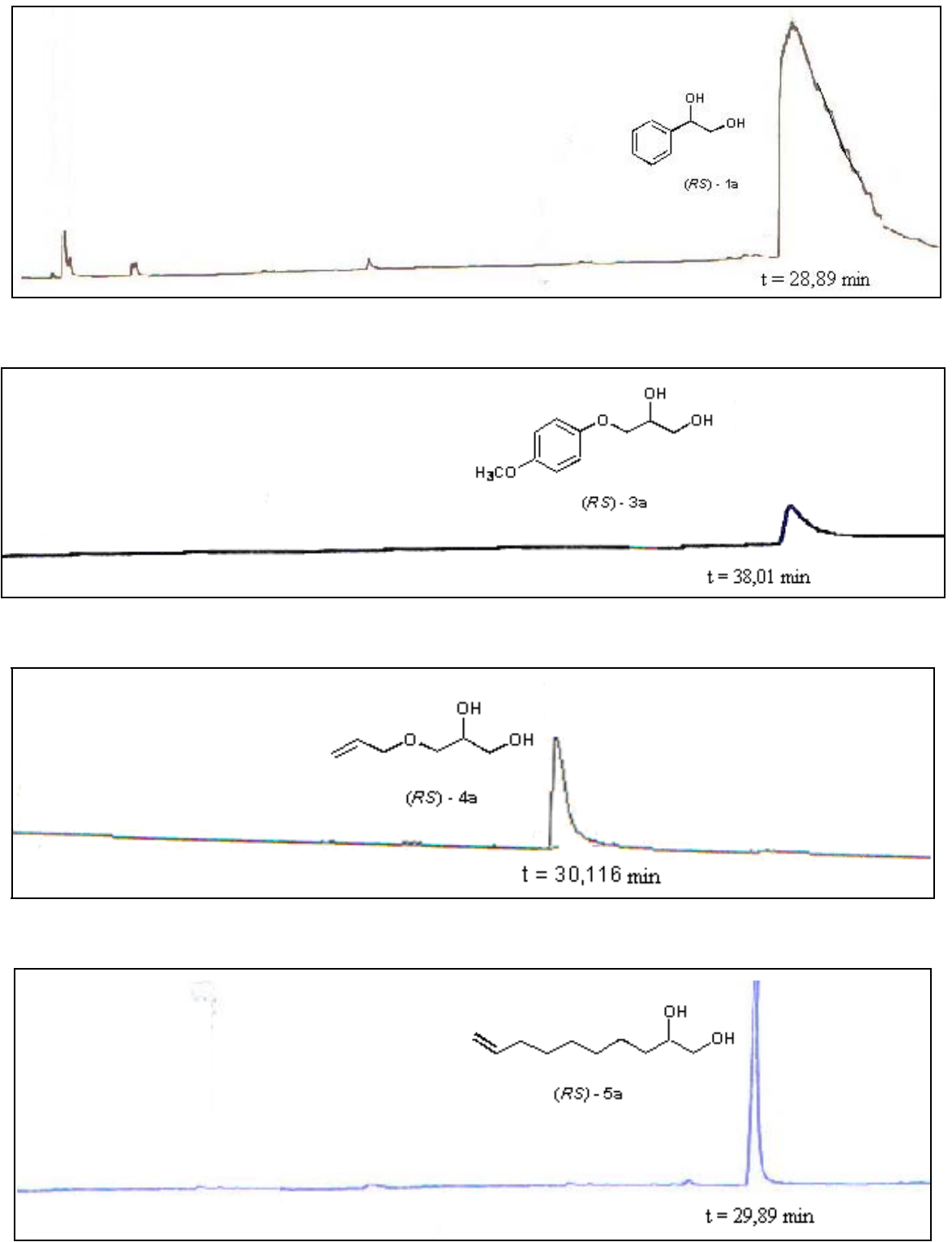

Figura 32. Cromatogramas dos dióis $(R S)-\mathbf{1 a},(R S)-\mathbf{3 a},(R S)-\mathbf{4 a}$ e $(R S)-\mathbf{5 a}$ obtidos por método químico em $C G$ quiral 
Assim como foi realizado para o epóxido 2, realizaram-se os brancos das reações dos para os epóxidos 1, 3-5 nas seguintes condições: i- água destilada; ii- água destilada + malte $3 \%$ $(\mathrm{m} / \mathrm{v})$; iii- solução tampão fosfato $(\mathrm{pH}=7)$. Os brancos realizados com a água do mar foram discutidos na Seção 4.2 .

Para os sistemas i e ii nenhum dos epóxidos apresentou hidrólise espontânea. Para o sistema iii somente o epóxido estireno 1 sofreu hidrólise espontânea formando o seu respectivo diol 1a (Figura 33). Isso provavelmente se deve à presença de um átomo de carbono benzílico favorecendo a abertura do anel oxirano no meio reacional.

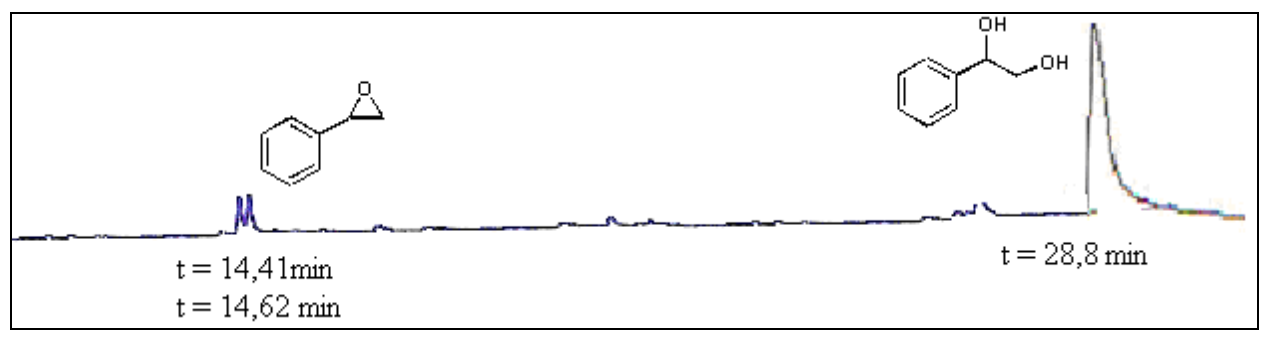

Figura 33. Cromatograma do epóxido $(R S)-1$ em tampão fosfato $(\mathrm{pH}=7)$

Portanto, o epóxido 1 não foi utilizado na reação biocatalítica com as células totais do fungo Trichoderma sp Gc1. As reações com este microrganismo foram realizadas com os epóxidos 3, 4 e 5 sob as mesmas condições experimentais realizadas com o epóxido 2, ou seja, utilizaram-se apenas as células do fungo cultivado em água do mar (5 g) e suspensas em solução tampão fosfato $(\mathrm{pH}=7)$. As reações foram monitoradas periodicamente e as análises foram realizadas em CG com coluna quiral onde buscou obter o tempo de reação mais eficiente na hidrólise destes epóxidos. Os dióis 3a-5a obtidos foram purificados por $\mathrm{CC}$ e seus respectivos rendimentos determinados. Foram realizadas as medidas de rotação ótica em um polarímetro para se determinar, quando possível, a configuração absoluta dos compostos conhecidos. Os valores encontram-se descritos na Tabela 8. 
Tabela 8: Hidrólise dos epóxidos 3, 4 e 5 com o fungo de origem marinha Trichoderma sp.Gc1. ${ }^{\text {a }}$

\begin{tabular}{|c|c|c|c|c|c|}
\hline Compostos & $\begin{array}{c}\text { Rendimento } \\
(\%)\end{array}$ & $\begin{array}{l}\text { e.e. } \\
(\%)\end{array}$ & $\begin{array}{l}{[\alpha]^{25} \mathrm{D}} \\
\text { experimental }\end{array}$ & $\begin{array}{c}{[\alpha]^{20}{ }_{D}} \\
\text { literatura }\end{array}$ & c.a. \\
\hline 3 & $\mathrm{Nd}^{*}$ & $\mathrm{Nd}^{*}$ & $\mathrm{Nd}^{*}$ & $\mathrm{Nd}^{*}$ & $\mathrm{Nd}^{*}$ \\
\hline 3a & 72 & $\mathrm{Nd}^{* *}$ & $\begin{array}{c}+30,12^{\circ} \\
\left(\text { c } 2.0, \mathrm{CHCl}_{3}\right)\end{array}$ & $\begin{array}{c}(R) \\
-7,14^{\circ} \\
\left(c 0.5, \mathrm{CHCl}_{3}\right)\end{array}$ & $(S)-\mathbf{3 a}$ \\
\hline 4 & 23 & 34 & $\begin{array}{c}+22,1^{\circ} \\
\left(\text { c } 2.0, \mathrm{CHCl}_{3}\right)\end{array}$ & $\begin{array}{c}(S) \\
+8,12^{\circ} \\
\left(c 0.8, \mathrm{CHCl}_{3}\right)\end{array}$ & $(S)-4$ \\
\hline $4 a$ & 68 & $\mathrm{Nd}^{* *}$ & $\begin{array}{c}-8,82^{\circ} \\
\left(c 2.0, \mathrm{CHCl}_{3}\right)\end{array}$ & $\begin{array}{c}(R) \\
-10,9^{\circ} \\
\left(c 0.8, \mathrm{CHCl}_{3}\right)\end{array}$ & $(R)-\mathbf{4 a}$ \\
\hline 5 & 28 & 26 & $\mathrm{Nd}$ & $\mathrm{Nd}^{* * *}$ & $\mathrm{Nd}^{* * *}$ \\
\hline $5 a$ & 56 & $\mathrm{Nd}^{* *}$ & $\begin{array}{c}-7,14^{\circ} \\
\left(\text { c } 2.0, \mathrm{CHCl}_{3}\right)\end{array}$ & $\mathrm{Nd}^{* * *}$ & $\mathrm{Nd}^{* * *}$ \\
\hline
\end{tabular}

a condições de reação: $5 \mathrm{~g}$ de massa celular de fungo; $100 \mathrm{mg}$ de epóxido; $400 \mu \mathrm{L}$ de DMSO; $150 \mathrm{rpm}$; $32{ }^{\circ} \mathrm{C}$; e.e. $=$ excesso enantiomérico; $[\alpha]^{\mathrm{T}}{ }_{\mathrm{D}}=$ rotação óptica específica; N.d. = Não determinado; c.a. = configuração absoluta; Ref.

= referência bibliográfica;

*O epóxido 3 não foi isolado, pois foi convertido totalmente no diol 3a;

**Não foi realizada a derivatização dos dióis 3a-5a nos respectivos diacetatos;

***Configuração absoluta não determinada.

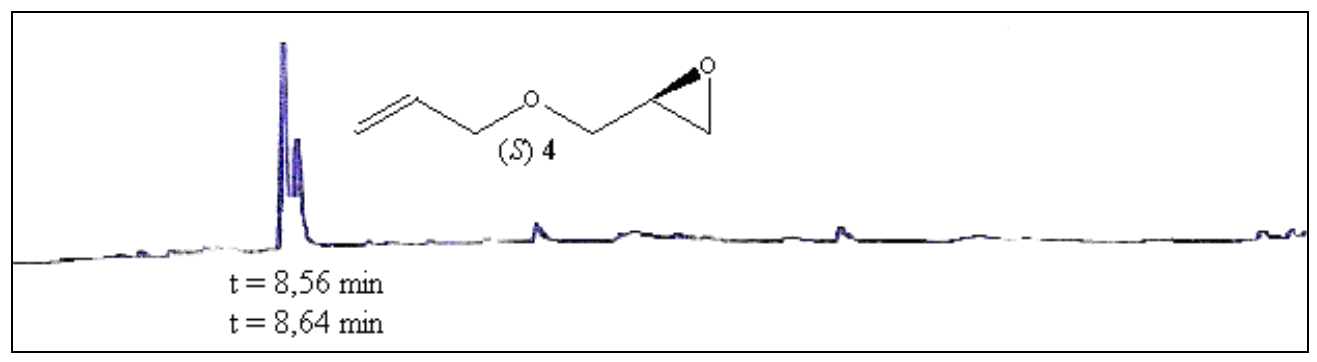

Figura 34. Cromatograma do epóxido $(S)-4$ obtido na reação de biocatálise com o fungo Trichoderma sp.Gc1 


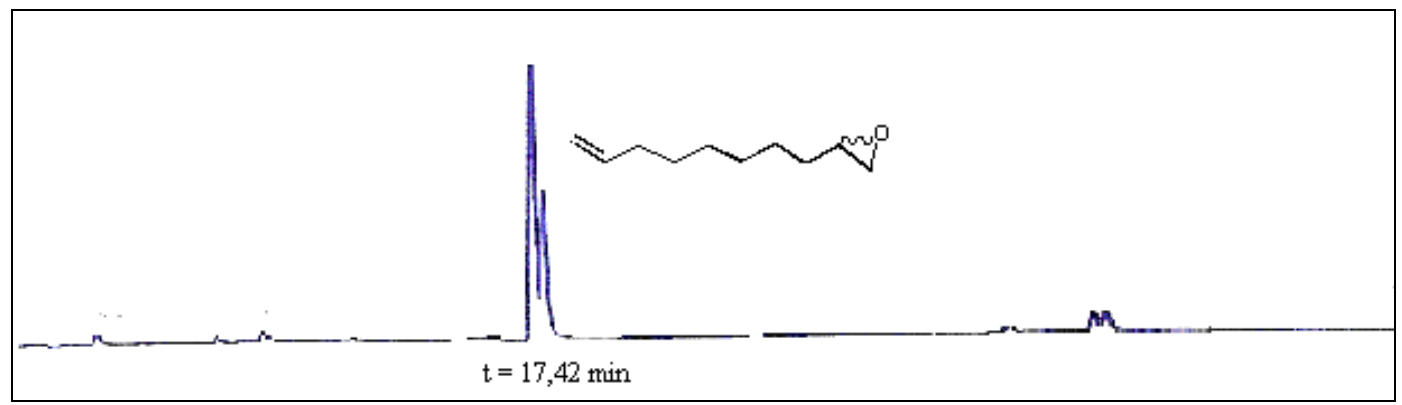

Figura 35. Cromatograma do epóxido $(R S)-5$ obtido na reação de biocatálise com o fungo Trichoderma sp.Gc1

Como pode ser observado na Tabela 8 a reação com o epóxido 3 formou o diol $(S)$-3a com um rendimento de $72 \%$. Contudo, o epóxido 3 não foi isolado do meio reacional impossibilitando de se realizar a medida de sua rotação ótica. O excesso enantiomérico do diol (S)-3a não foi determinado, pois não ocorreu resolução dos enantiômeros na coluna quiral utilizada. Em todos os casos, observou-se que os dióis não forneceram bons sinais nas análises por CG quiral, devido à alta polaridade destes compostos.

A reação de hidrólise do $(R S)-\mathbf{4}$ forneceu o epóxido $(R)-\mathbf{4}$ enantiomericamente enriquecido, pois se obteve uma pureza enantiomérica de $34 \%$ e um rendimento de $23 \%$, enquanto que o diol (S)-4a foi obtido com rendimento de $68 \%$. Assim como observado para epóxido 2, o fungo Trichoderma sp.Gc1 converteu seletivamente o epóxido (S)-4 no respectivo diol (S)-4a com retenção da configuração absoluta, fornecendo um produto heteroquiral (Figura $35 a)$. 


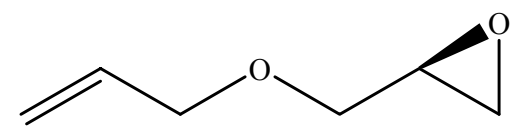

(S)-4

e.e. $34 \%$

rendimento $23 \%$

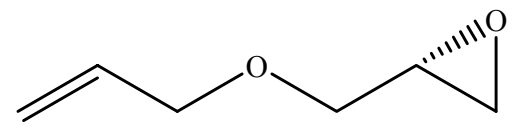

$(R)-4$

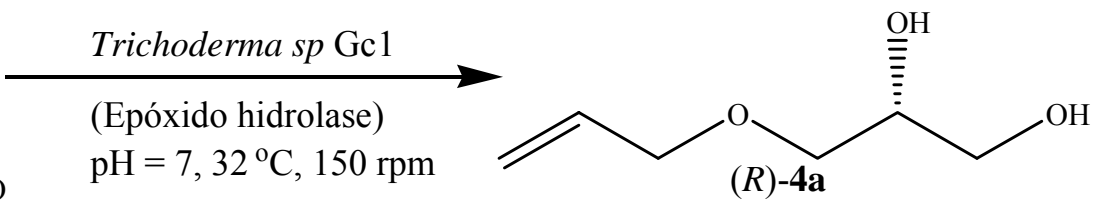

rendimento $68 \%$

Figura 35a. Hidrólise seletiva do (RS)-4a com o fungo Trichoderma sp GC1

A reação de hidrólise enzimática com o epóxido $(R S)-\mathbf{5}$ forneceu o epóxido 5 com pureza enantiomérica de $26 \%$ e rendimento de $28 \%$. Enquanto que o diol 5 a foi obtido com um rendimento de $56 \%$, cujo valor de rotação ótica para o diol $5 a$ foi $[\alpha]^{25}=-7,14^{\circ}\left(c\right.$ 2.0, $\left.\mathrm{CHCl}_{3}\right)$.

Através destes estudos concluiu-se que o fungo Trichoderma sp Gc1 é um potencial biocatalisador para ser utilizado na abertura seletiva dos epóxidos racêmicos. As enzimas epóxidos hidrolases foram ativas e promoveram a conversão dos epóxidos em seus respectivos dióis. Certamente que as condições experimentais podem ser otimizadas, para fornecer melhores resultados quando aos rendimentos das reações bem como em relação à pureza enantiomérica dos produtos formados nas reações biocatalíticas. 


\section{2 - Síntese e resolução enzimática de cloroidrinas}

\subsection{1 - Síntese de cloroidrinas a partir de epóxidos racêmicos}

A formação espontânea da cloroidrina $\mathbf{2 b}$ a partir da abertura do epóxido 2 em água do mar artificial, demonstrou ser uma reação interessante para a obtenção de cloroidrinas a partir de epóxidos. Inclusive obteve-se para esta reação um rendimento de $84 \%$ na cloridrina $2 \mathbf{b}$. Conhecendo-se também o interesse no desenvolvimento de metodologias simples para a síntese de cloroidrinas a partir de epóxidos, decidiu-se por otimizar esta reação. As condições de abertura de epóxidos na presença de íons cloreto foram avaliadas neste trabalho, utilizando-se como substratos os mesmos epóxidos utilizados nas reações de biocatálise com o fungo Trichoderma sp. Gc1.

As reações foram realizadas em uma solução aquosa de cloreto de sódio, uma vez que o íon cloreto está presente em maior proporção na água do mar artificial (3\% m/v). Inicialmente, realizaram-se alguns experimentos com o epóxido $2(100 \mu \mathrm{L})$ em diferentes concentrações de cloreto de sódio $(0,5 ; 1,0 ; 1,5$ e 2,0 g) que foram dissolvidos em $10 \mathrm{~mL}$ de água destilada. As reações foram monitoradas por $\mathrm{CG}$ e observou-se que acima de $1,5 \mathrm{~g}$ de solução de $\mathrm{NaCl}$ pouca diferença ocorreu na conversão do epóxido 2 na cloroidrina 2b. Assim, as reações foram realizadas utilizando-se 1,5 $\mathrm{g} \mathrm{NaCl} / 10 \mathrm{~mL}$ de água com os epóxidos 1-5. Os cromatogramas obtidos para essas reações estão apresentados na Figura 36. 

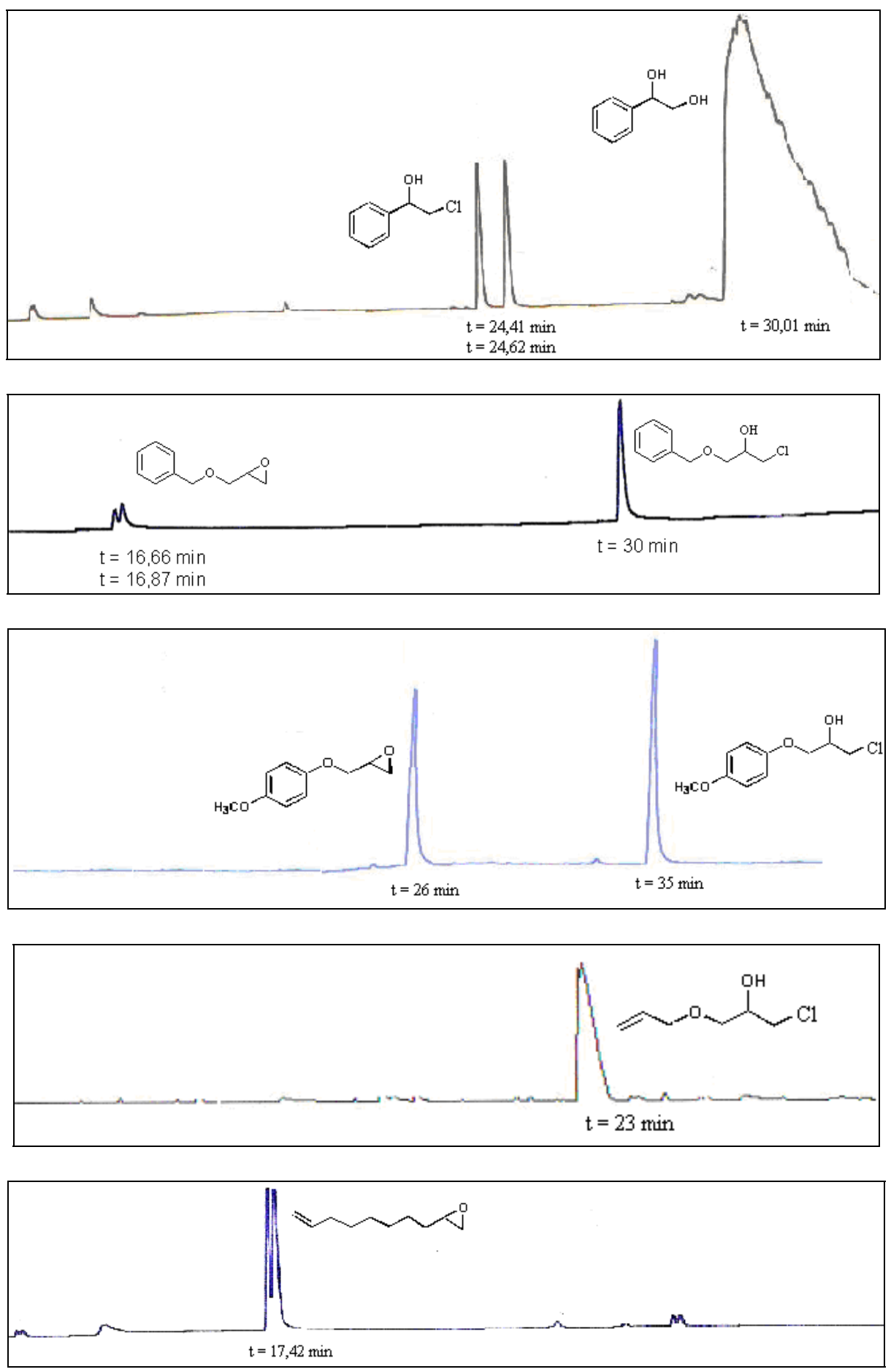

Figura 36. Cromatogramas dos epóxidos 1-5 para reação em $\mathrm{NaCl}$ e água 
Como pode ser observado nos cromatogramas da Figura 36 os epóxidos 1a-5a apresentaram diferentes comportamentos. $\mathrm{O}$ epóxido 5 praticamente não produziu a cloroidrina 5b. A hidrólise do epóxido 1 formou majoritariamente o diol 1a, apresentando uma pequena conversão na sua cloroidrina 1b. Portanto os epóxidos 1 e 5 não foram substratos adequados para sintetizar as respectivas cloroidrinas $\mathbf{1 b}$ e $\mathbf{5 b}$.

Em seguida, as reações com os epóxidos 2-4 foram realizadas em triplicata para determinar os rendimentos dos produtos. Neste caso realizaram-se as reações em maior escala (15 g $\mathrm{NaCl} / 100 \mathrm{~mL}$ de água e $100 \mu \mathrm{L}$ de epóxidos). Os resultados das reações encontram-se sumarizados na Figura 37. Como podem ser observados as cloroidrinas $\mathbf{3 b}$ e $\mathbf{4 b}$ foram obtidas em bons rendimentos. As análises em coluna quiral de $\beta$-ciclodextrina permitiram a separação dos seus respectivos enantiômeros. Assim, com o objetivo de obter a cloroidrina $\mathbf{4 b}$ em sua forma enantiomericamente pura, realizou-se uma resolução enzimática com a lipase de Candida antartica B (CALB).

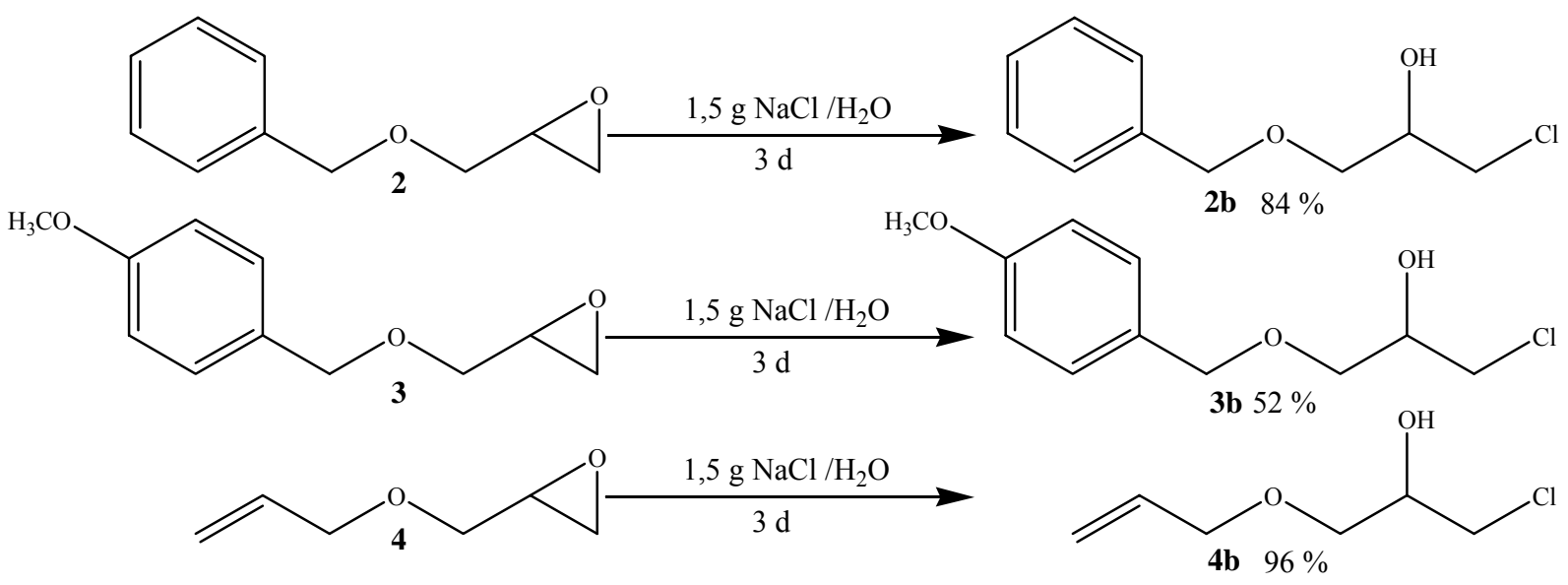

Figura 37. Síntese das cloroidrinas $2 \mathbf{b}-\mathbf{4 b}$ a partir dos epóxidos 2-4 


\subsection{2 - Resolução enzimática de 1-alilóxi-3-cloro-2-propanol (4b) com a lipase de Candida antarctica (CALB)}

O catalisador biológico utilizado na resolução enzimática da cloroidrina $\mathbf{4 b}$ foi a lipase B de Candida antarctica (CALB) conhecida comercialmente por Novozym ${ }^{\circledR} 435$.

\subsubsection{1 - Síntese de acetato racêmico obtido por método químico}

Para realizar a resolução enzimática da cloroidrina $\mathbf{2 b}$ sintetizou-se inicialmente o acetato racêmico $(R S)$-4c. A reação de esterificação foi facilmente realizada com cloroidrina $(R S)-\mathbf{4 b}$, conforme em procedimento descrito na Seção 3.2.2. Após purificação pro cromatografia em coluna obteve-se $89 \%$ de rendimento do acetato (RS)-4c (Figura 38).

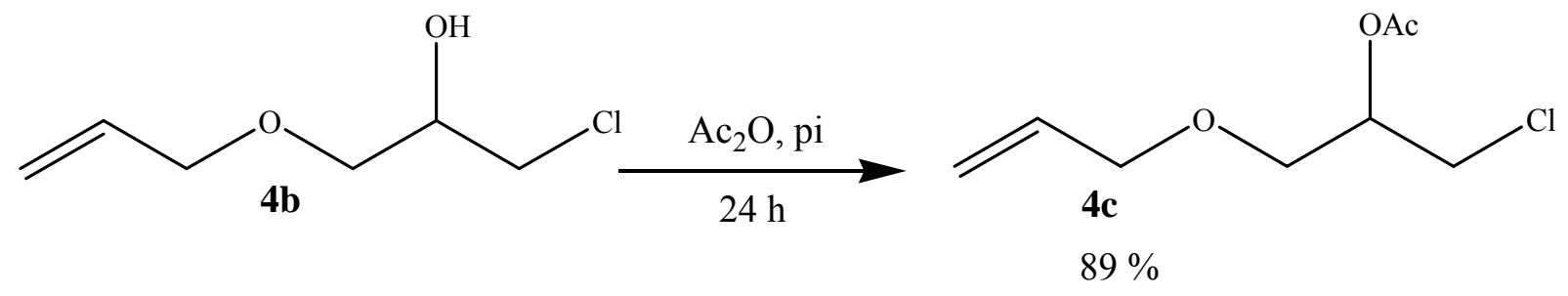

Figura 38. Acetato obtido a partir da cloroidrina $\mathbf{4 b}$

$\mathrm{O}$ acetato $(R S)-4 \mathrm{c}$ foi analisado na coluna VARIAN WCOT Fused Sílica $25 \mathrm{~m} \mathrm{x}$ $0,25 \mathrm{~mm} \times 0,39 \mu \mathrm{m}$ com fase estacionária CP-Chirasil-Dex CB. Pode-se observar que os enantiômeros do acetato foram muito bem resolvidos na coluna quiral, pois se obteve dois picos no cromatograma com tempos de retenção de 12,47 e 13,76 minuto (Figura 39). 


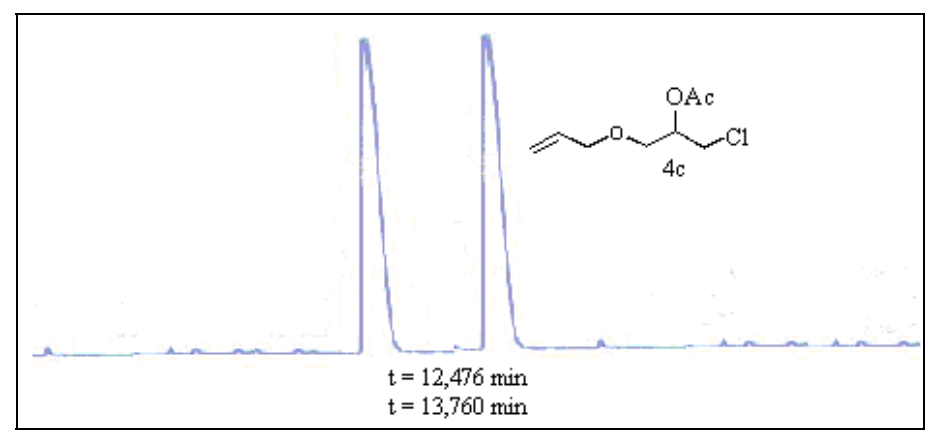

Figura 39. Cromatograma do acetato $(R S)$-4c obtido por método químico.

Reação de resolução enzimática da cloroidrina (RS)-4b com a lipase de Candida antarctica

Pode-se observar pelos cromatogramas da Figura 40 que a cloroidrina $\mathbf{4 b}$ apresentou uma conversão eficiente no seu respectivo acetato 4c a partir de 1 hora de reação. Verificou-se uma preferência na esterificação de um dos seus enantiômeros, no intervalo de tempo de 1 a 10 horas de reação, após este tempo o outro enantiômero de 4 c começou a ser formado. O maior valor de excesso enantiomérico (e.e. > $99 \%$ ) para o acetato 4c ocorreu entre 1-5 h de reação. Contudo, para esse intervalo de tempo, a cloroidrina $\mathbf{4 b}$ deve apresentar um excesso enantiomérico baixo. Com a extensão da reação até $24 \mathrm{~h}$ obteve-se após purificação por cromatografia em coluna a cloridrina $\mathbf{4 b}$ com rendimento de $38 \%$ e pureza enantiomérica de $72 \%$. Enquanto que o acetato $4 \mathrm{c}$ foi obtido com $74 \%$ de rendimento e excesso enantiomérico de $81 \%$. Na Figura 40 tem os picos dos cromatogramas correspondentes à resolução enzimática com a lipase C. antractica. O excesso enantiomérico de $\mathbf{4 b}$ foi calculado após derivatização, convertendo-se a cloroidrina $\mathbf{4 b}$ em seu respectivo acetato $4 \mathbf{c}$ realizando-se a acetilação com anidrido acético e piridina (Seção 3.2.2). A configuração absoluta dos compostos obtidos não foi determinada. 
Tabela 9. Esterificação da cloroidrina 4b com a lípase de Candida antarctica ${ }^{\mathrm{a}}$

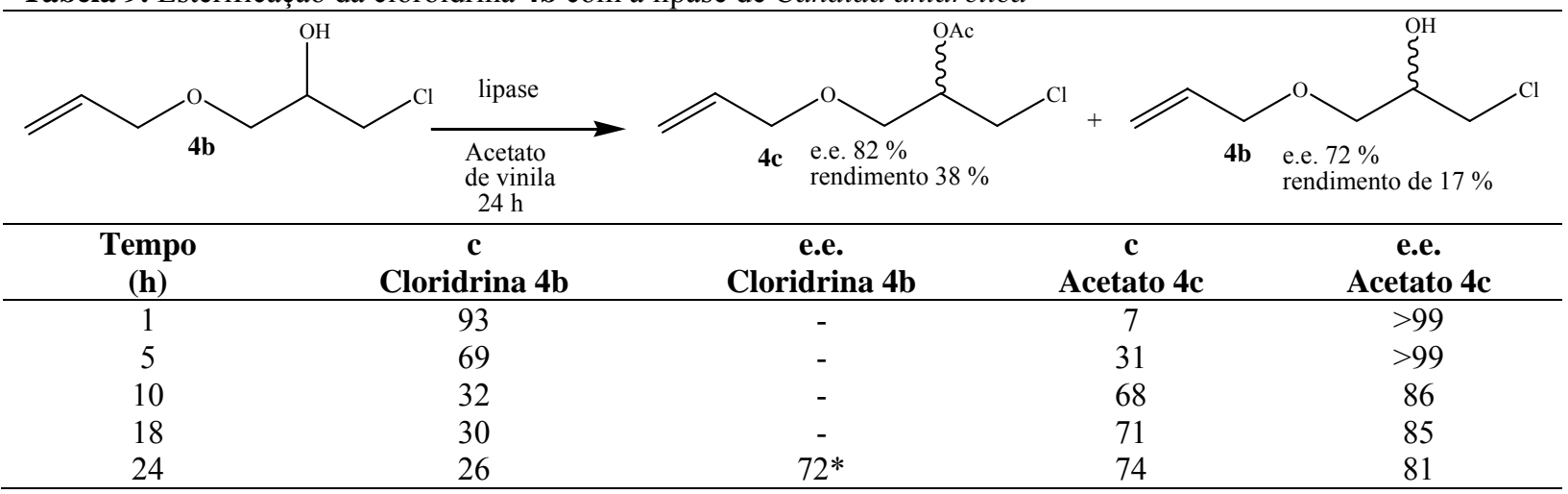

${ }^{a}$ condições de reação: $5 \mathrm{~mL}$ de hexano; $0,5 \mathrm{~mL}$ de acetato de vinila; $40 \mathrm{mg}$ da lípase; $40 \mu \mathrm{L}$ de cloroidrina $4 \mathbf{b}$; $150 \mathrm{rpm} ; 32{ }^{\circ} \mathrm{C}$; c $(\%)=$ concentração determinada por $\mathrm{CG}$; ee $(\%)=$ excesso enantiomérico; *e.e. determinado após derivatização via reação de acetilação.

- 1 h de reação

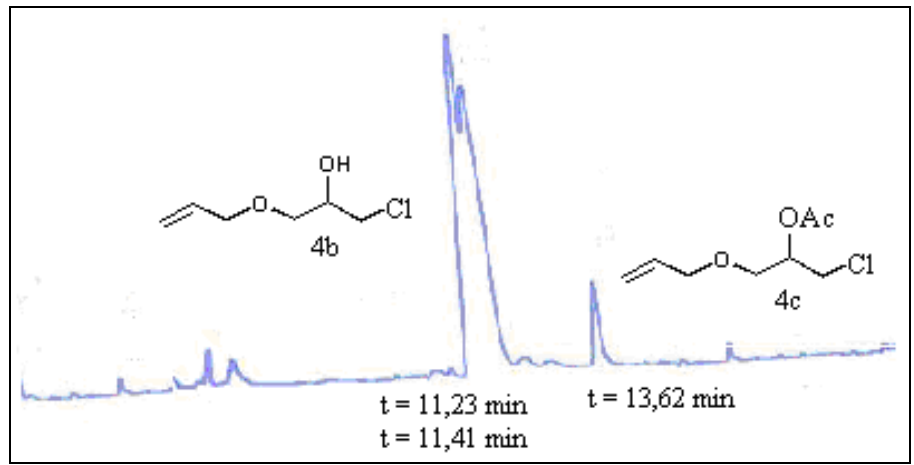

- 5 h de reação

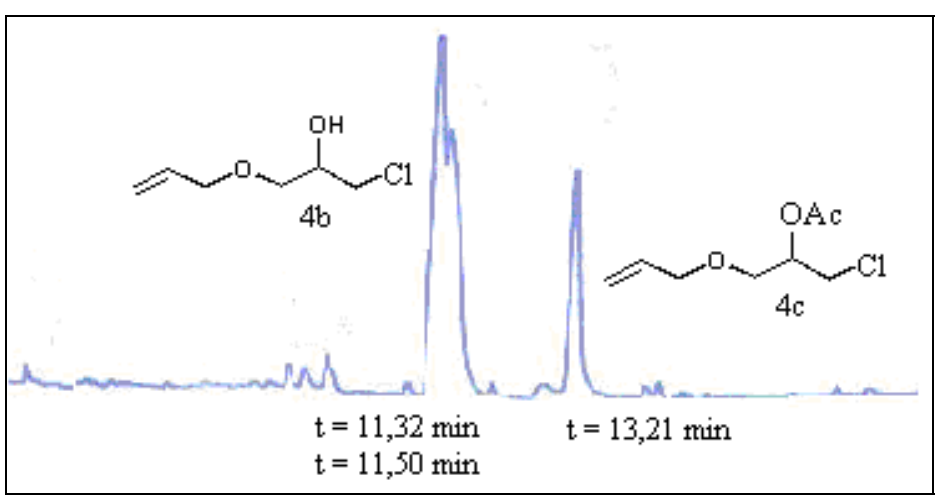


- $10 \mathrm{~h}$ de reação

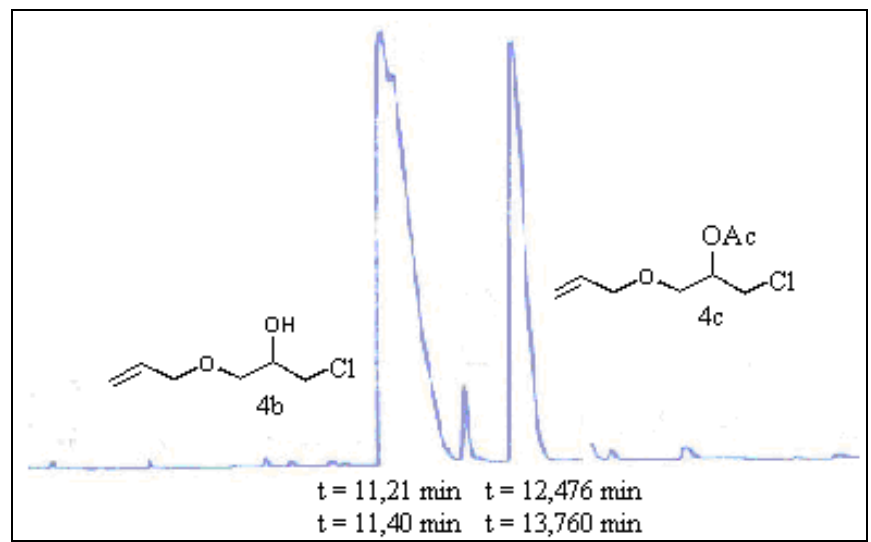

- 18 h de reação

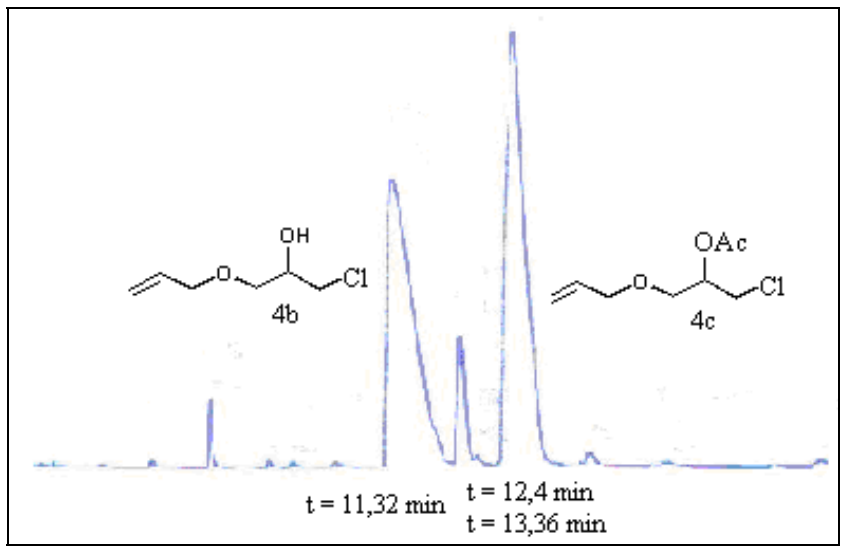

- 24 h de reação

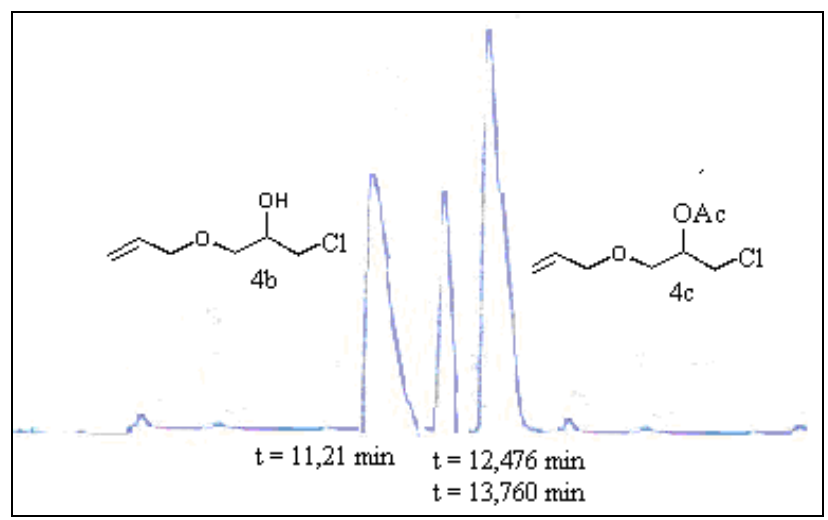

Figura 40: Cromatogramas para a reação da cloroidrina $4 b$ com a lipase. 
Pode-se concluir que a lipase de Candida antarctica B apresentou uma eficiente resolução enantiomérica do 1-alilóxi-3-cloro-2-propanol 4a, com bons rendimentos e excessos enantioméricos altos para os produtos obtidos. Outras cloridrinas poderão ser sintetizadas na forma enantiomericamente puras ou enriquecidas por resolução enzimática com lipase de $C$. antarctica. 


\section{CONCLUSÕES}

Nesse trabalho foram sintetizados dióis racêmicos (1a-5a) em bons rendimentos a partir da hidrólise ácida dos respectivos epóxidos (1-5).

Realizaram-se uma triagem com os fungos de origem marinha (Penicillium miczynskii Gc5, Trichoderma sp. Gc1, Aspergillus sydowii Gc12 e Penicillium raistrickii Ce16) para catalisar a hidrólise de epóxidos. Selecionou-se os fungos Trichoderma sp. Gc1 e Aspergillus sydowii Gc12, pois catalisaram seletivamente a hidrólise do epóxido (RS)-2. As enzimas epóxidos hidrolases dos fungos Trichoderma sp. Gc1 e A. sydowii Gc12 foram enantiocomplementares na hidrólise de (RS)-2.

A produção das enzimas epóxidos hidrolases do fungo Trichoderma sp. Gc1 mostraram uma dependência do cultivo em água do mar artificial, devido a alta concentração de íons cloreto. O uso de células totais do fungo Trichoderma sp. Gc1 cultivado em água destilada não catalisou a abertura do epóxido (RS)-2.

A abertura de epóxidos em solução aquosa de cloreto de sódio foi uma metodologia eficiente para sintetizar as cloroidrinas $\mathbf{2 b} \mathbf{b} \mathbf{4} \mathbf{b}$, pois se realizou as reações com reagentes inócuos e de baixo custo.

A resolução enzimática da cloroidrina $\mathbf{4 b}$ com a lipase de Candida antarctica foi eficiente, pois se obteve a cloroidrina $\mathbf{4 b}$ e seu respectivo acetato $\mathbf{4 c}$ com bons rendimentos e elevados excessos enantioméricos. A lipase de Candida antarctica poderá ser utilizada em resoluções enzimáticas para preparar outras cloroidrinas com elevadas purezas enantioméricas. 


\section{REFERÊNCIAS BIBLIOGRÁFICAS}

1. PRADO, A. G. S. Química verde, os desafios da química do novo milênio. Química Nova, v. 26, n. 5 , p. $738-744,2003$.

2. SILVA, F. M.; LACERDA, P. S. B.; JUNIOR, J. Desenvolvimento sustentável e química verde. Química Nova, v. 28, n. 1, p. 103-110, 2005.

3. SILVERMAN, R. B. The organic chemistry of enzyme-catalyzed reactions. San Diego: Academic Press, 2000. 717p.

4. NELSON, D. L; COX, M. M. Lehninger: principles of biochemistry. 3. ed. New York: Worth Publishers, 2000. 1152p.

5. FABER, K. Biotranformations in organic chemistry. 5 ed. New York: Springer, 2004. 718p.

6. SÍTIO ativo das enzimas. Disponível em: <http://www.ciagri.usp.br>. Acesso em: 19 jun. 2008.

7. NAKAMURA, K.; YAMANAKA, R.; MATSUDA, T.; HARADA, T. Recent developments in asymmetric reduction of ketones with biocatalysts. Tetrahedron: Asymmetry, v. 14, n. 60, p. 26592681, 2003.

8. LERESCHE, J.; MEYER, H. P. Chemocatalysis and Biocatalysis (Biotransformation): Some thoughts of chemist and of a biotechnologist. Organic Process Research e Development, v. 10, p. 572-580, 2006.

9. KIRK, O.; BORCHERT, T. V.; FUGLSANG, C. C. Industrial enzyme applications. Current Opinion in Biotechnology, v. 13, n. 4, p. 345-351, 2002.

10. SAID, S.; PIETRO, R. Enzimas de interesse industrial e biotecnológico. Rio de Janeiro: Eventos, 2002. 1152p.

11. POLLARD, D. V.; WOODLEY, J. M. Biocatalysis for pharmaceutical intermediates: the future is now. Trends in Biotechnology, v. 25, n. 2, p. 66-73, 2007. 
12. O FENÔMENO da quiralidade - bases de estereoquímica. Disponível em:

$<\mathrm{http}: / /$ www.spq.pt/boletim/docs/boletimSPQ_103_056_09.pdf $>$. Acesso em: 29 maio 2007.

13. GHANEM, A. Trends in lipase-catalyzed asymmetric access to enantiomerically pure/enriched compounds. Tetrahedron, v. 63, n. 786, p. 1721-1754, 2007.

14. CAZETTA, Tarcila. Resolução cinética dinâmica da ( \pm )-2-hidroxi-1-indanona mediada por Trichosporon cutaneum. 2006. 207 f. Dissertação (Mestre em Química na Área de Química Orgânica) - Instituto de Química, Universidade Estadual de Campinas, Campinas, 2006.

15. EMBA, E. S. C.; OLIVEIRA, I. M. F.; DONNICI, C. L. Álcooos quirais: métodos químicos e catalíticos de obtenção por redução assimétrica. Química Nova, v. 26, n. 1, p. 112-122, 2003.

16. MARPLES, B. A. Elementary organic stereochemistry and conformational analysis. London: The Royal Society of Chemistry, 1981. 82p.

17. SOLOMONS, T. W. G. Organic chemistry, 5 ed. New York: John Wiley, 1992. 432p.

18. BONATO, P. S. Cromatografia gasosa. In: COLLINS, C. H.; BRAGA, G. L.; BONATO, P. S. (Org). Fundamentos de cromatografia. Campinas: Editora da UNICAMP, 2006. p. 203-272.

19. ETHUR, E. M. Síntese e caracterização de $\beta$ - e $\gamma$-ciclodextrinas modificadas como fases estacionárias quirais em cromatografia gasosa capilar enantiosseletiva. 2004. $147 \mathrm{f}$. Tese (Doutorado) - Programa de Pós-Graduação em Química, Universidade Federal de Santa Maria, Santa Maria, 2004.

20. BOTOLLI, C. B. G.; JARDIM, I. C. S. F.; COLLINS, C. H. Cromatografia líquida de alta eficiência. In: CANEVAROLO, S. V. (Coord.). Técnicas de caracterização de polímeros. São Paulo: Artliber Editora, 2004. p. 95-115.

21. JARDIM, I. C. S. F.; COLLINS, C. H.; GUIMARÃES, L. F. L. Cromatografia líquida de alta eficiência. In: COLLINS, C. H.; BRAGA, G. L.; BONATO, P. S.(Org). Fundamentos de cromatografia. Campinas: Editora da UNICAMP, 2006. p. 273-398.

22. FINNEY, N. S. Enantioselective epoxide hydrolysis: catalysis involving microbes, mammals and metals. Chemical and Biology, v. 5, n. 4, p. 73-79, 1998. 
23. BESSE, P.; VESCHAMBRE, H. Chemical and Biological Syntesis of Chiral Epoxides.

Tetrahedron, v. 50, n. 30, p. 8885-8927, 1994.

24. ARCHELAS, A.; FURSTOSS, R. Epoxide Hydrolases: New tools for the synthesis of fine organic chemicals. Tibtechnology, v. 16, p. 108-116, 1998.

25. KIM, H. S.; LEE, O. K.; LEE, S. J.; HWANG, S.; KIM, S. J.; YANG, S.; PARK, S.; LEE, E. Y. Enantioselective epoxide hydrolase activity of newly isolated microorganism, Sphingomonas echinoides EH-983, from seawater. Journal of Molecular Catalysis, v. 41, p. 130-135, 2006.

26. ARMSTRONG, R. N. Kinetic and Chemical Mechanism of Epoxide Hidrolase. Drug Metabolism Reviews, v. 31, p. 71-86, 1999.

27. ORRU, R. V.; FABER, K. Stereoselectivities of microbial epoxide hydrolases. Current Opinion in Chemical Biology, v. 3, p. 16-21, 1999.

28. ENZIMAS. Disponível em: < http://www.enq.ufsc.br/labs/probio/disc_eng_bioq/ lista_exerc/enzimas_aspectos_gerais.pdf $>$.Acesso em: 10 maio 2007.

29. SUZUKI, Y.; MARUMO, S. Fungal metabolism of ( \pm )-epoxyfarnesol and its absolute stereochemistry. Tetrahedron Letters, v. 13, n. 19, p. 1887-1890, 1972.

30. ZHANG, X. M.; ARCHELAS, A.; FURSTOSS, R. Microbial transformations. 19. Asymmetric dihydroxylation of the remote double bond of geraniol: a unique stereochemical control allowing easy access to both enantiomers of geraniol-6,7-diol. Tetrahedron Letters, v. 56, n. 12, p. 3814$3817,1991$.

31. MONFORT, N.; ARCHELAS, A.; FURSTOSS, R. Enzymatic transformations. Part 53: Epoxide hydrolase-catalysed resolution of key synthons for azole antifungal agents. Tetrahedron: Asymmetry, v. 13, n. 22, p. 2399-2401, 2002.

32. PEDRAGOSA-MOREAU, S.; ARCHELAS, A.; FURSTOSS, R. Microbiological transformations. 31: Synthesis of enantiopure epoxides and vicinal diols using fungal epoxide hydrolase mediated hydrolysis. Tetrahedron Letters, v. 37, n. 19, p. 3319-3322, 1996.

33. ZHANG, J.; REDDY, J.; ROBERGE, C.; SENANAYAKE, C.; GREASHAM, R.; CHARTRAIN, M. Chiral bio-resolution of racemic indene oxide by fungal epoxide hydrolases. Journal of Fermentation and Bioengineering, v. 80, n. 3, p. 244-246, 1995. 
34. YAMAGUCHI, H.; SHIRASAKA, N.; IKUNAKA, M. Producing microorganisms with enhanced epoxide hydrolase activity, which is useful as organic synthesis reagent for producing optically active compound from epoxide, involves culturing microorganisms in culture medium comprising starch. JP2006158209-A, 22 jun. 2006.

35. RANU, B. C.; BANERJEE, S. Ionic liquid as reagent. A green procedure for the regioselective conversion of epoxides to vicinal halohydrins using [AcMIm]X under catalyst- and solvent-free conditions. Journal of Organic Chemistry, v. 70, p. 4517-4519, 2005.

36. SPELBERG, J. H. L.; VLIEG, J. E. T.; BOSMA, T. A tandem enzyme reaction to produce optically active halohydrins, epoxides and diols. Tetrahedron: Asymmetry, v. 10, p. 2863-2870, 1999.

37. JAEGER, K. E.; EGGERT, T. Lipases for Biotecnology. Current Opinion in Biotechnology, v. 13, p. 390-397, 2002.

38. REETZ, M. T.; ZONTA, A.; SIMPELKAMP, J. Efficient heterogeneous biocatalysts by entrapment of lipases in hydrophobic sol-gel materials. Tetrahedron: Asymmetry, v. 34, p. 301303, 1995.

39. KOTIK, M.; BRICHAC, J.; KYSLIK, P. Novel microbial epoxide hydrolases for biohydrolysis of glycidyl derivates. Journal of Biotechnology, v. 120, p. 364-375, 2005.

40. ANDERSON, E.M., KARIN, M., KIRK, O. One biocatalyst - Many applications: The use of Candida antarctica B-lipase in organic synthesis. Biocatalysis and Biotransformation, v. 16, p. 181-204, 1998.

41. A enzima CALB utilizada nesse trabalho foi doada pela empresa Novonordisk (Araucárea, Paraná)

42. STEINREIBER, A.; OSPRIAN, I.; MAYER, S. F.; ORRU, R. V.A.; FABER, K. Enantioselective hydrolysis of functionalized 2,2-disubstituted oxiranes with bacterial epóxido hydrolases. Europe Journal Organic Chemistry, v. 37, p. 32-37, 2000. 
